\title{
Effects of Volcanic Ash Deposition and the Manson Impact on Marine Paleoredox and Paleoproductivity: Geochemical Evidence from the Cretaceous Pierre Shale
}

Isabella Cross-Najafi

Follow this and additional works at: https://researchrepository.wvu.edu/etd

\section{Recommended Citation}

Cross-Najafi, Isabella, "Effects of Volcanic Ash Deposition and the Manson Impact on Marine Paleoredox and Paleoproductivity: Geochemical Evidence from the Cretaceous Pierre Shale" (2017). Graduate Theses, Dissertations, and Problem Reports. 5410.

https://researchrepository.wvu.edu/etd/5410

This Thesis is protected by copyright and/or related rights. It has been brought to you by the The Research Repository @ WVU with permission from the rights-holder(s). You are free to use this Thesis in any way that is permitted by the copyright and related rights legislation that applies to your use. For other uses you must obtain permission from the rights-holder(s) directly, unless additional rights are indicated by a Creative Commons license in the record and/ or on the work itself. This Thesis has been accepted for inclusion in WVU Graduate Theses, Dissertations, and Problem Reports collection by an authorized administrator of The Research Repository @ WVU. For more information, please contact researchrepository@mail.wvu.edu. 
EFFECTS OF VOLCANIC ASH DEPOSITION AND THE MANSON IMPACT ON MARINE PALEOREDOX AND PALEOPRODUCTIVITY: GEOCHEMICAL EVIDENCE FROM THE CRETACEOUS PIERRE SHALE

\author{
Isabella Cross-Najafi \\ Thesis submitted \\ to the Eberly College of Arts and Sciences \\ at West Virginia University \\ in partial fulfillment of the requirements for the degree of \\ Master of Science in Geology
}

Shikha Sharma, Ph.D., Chair

Jaime Toro, Ph.D.

Daniel Soeder, M.S.

Department of Geology

Morgantown, West Virginia

2016

Keywords: Geochemistry, Pierre Shale, Stable Isotopes, Trace Elements

Copyright 2016 Isabella Cross-Najafi 


\section{ABSTRACT \\ Effects of Volcanic Ash Deposition and the Manson Impact on Marine Paleoredox and}

Paleoproductivity: Geochemical Evidence from the Cretaceous Pierre Shale

\section{Isabella Cross-Najafi}

The Pierre Shale Group is a massive black shale deposited in the Late Campanian during the Cretaceous Period. There is limited research on organic carbon content of the Pierre Shale in South Dakota. Frequent volcanic eruptions combined with climate change resulted in an increase in carbon dioxide in the atmosphere, leading to decreases in marine oxygen content. Decreasing marine oxygen has been attributed to higher amounts of preserved organic matter in marine sediment. Impact of volcanic ash deposition in the Cretaceous Interior Seaway has not been thoroughly studied. The Pierre Shale also contains the Crow Creek Member, a 5 foot thick layer of unconsolidated sand and rip-up clasts which may indicate a high-energy depositional event. Some hypothesize that it was deposited by a tsunami generated by the Manson impact. Others believe the Crow Creek Member is evidence of a marine low-stand that occurred before the Bearpaw Cyclothem. It is possible that the depositional event that deposited the Crow Creek Member may have led to increases in organic carbon preservation depending on the burial rates and amount of organic carbon preserved.

To investigate the connection between volcanic ash deposition, the Crow Creek Member deposition, and organic matter preservation of the coastal Cretaceous Interior Seaway, stable isotope geochemistry, trace element geochemistry, and total organic carbon analyses were performed on a 500 foot core drilled near Fort Pierre, South Dakota. Ash beds were identified using X-ray diffraction analysis. Core sampling was driven by location of the Crow Creek Member (above below and within one foot) and by location of ash beds (above below and within one inch), but samples were also taken based on highest and lowest gamma ray values for each five foot $(1.52 \mathrm{~m})$ core segment. Core sampling was restricted because every other five foot (1.52 meter) section of the Treedam core segment was available for sampling. Statistical T-tests and Ztests were performed on sample data to determine if there was a significant difference in geochemical signatures between core deposited before and after ash bed deposition and Crow Creek Member deposition. Results and $\mathrm{T}$ and $\mathrm{Z}$ statistical analyses show no significant changes in stable isotopes nor trace elements as a result of ash bed deposition nor the Crow Creek Member depositional event. Results also indicate that variability of the coastal brackish marine system made any significant trends harder to isolate on such a small scale. Overall $\delta^{13}$ Corg signatures ( -27 to $-26 \%$ ) indicate that the Cretaceous Interior Seaway was deposited in a brackish shallow marine environment and that there were no drastic changes in sea level throughout the deposition of the Pierre Shale Group that was sampled (Gregory Member up through Virgin Creek Member). The $\delta^{15} \mathrm{~N}$ data range ( -6 to $+1 \%$ ) show that fixed nitrogen was scarce during the deposition of the Pierre Shale and that most of the available marine nitrogen was likely fixed by cyanobacteria. 


\section{ACKNOWLEDGEMENTS}

I would first like to thank my thesis advisor Dr. Shikha Sharma of the department of Geology and Geography at West Virginia University Morgantown, who had faith in me and accepted me as her graduate student. Her guidance and experience helped me follow my own research path and inspired me to produce a master's thesis I can be proud of.

I would like to thank my committee members Dr. Jaime Toro of the Stable Isotope Lab at West Virginia University, and Daniel Soeder from the National Energy Technology Laboratory site in Morgantown, who helped me develop and polish my project by providing valuable insight and guidance.

I would like to thank everyone at South Dakota School of Mines and RESPEC for the Treedam core samples and lithology logs. I would like to thank Chloe Wonnell, Rachelle Thorne, and Harvey Eastman for helping me with Treedam core sampling and TOC analysis. Special thanks to Tracy Bank at the National Energy Technology Laboratory in Pittsburgh for processing all Treedam ICP-MS samples for this project, and to Ajay Ankara for running my samples for stable isotope analysis, and teaching me how to do sample preparation while putting up with my incessant questions.

Lastly, I would like to thank my friends, family, labmates, and my boyfriend Josh, whose undying support motivated me to reach the finish line. This accomplishment would not have been possible without them.

Thank you,

Isabella Cross-Najafi 


\section{TABLE OF CONTENTS}

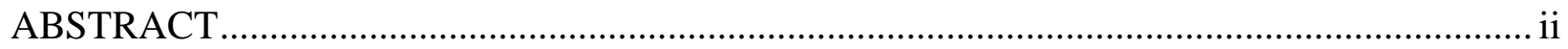

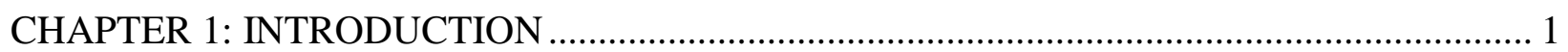

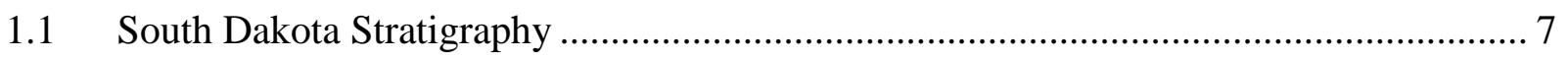

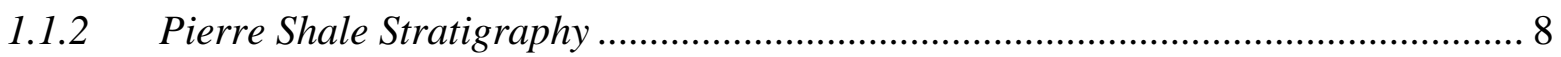

1.2 Pierre Shale Depositional Environment ........................................................... 11

1.3 Volcanic Effects on Productivity, Redox Conditions, and Organic Matter Preservation

1.4 Research Objectives and Hypotheses.................................................................... 17

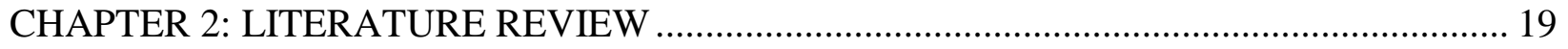

2.1 Overview of Shale Formation and Organic Matter Preservation ................................. 19

2.2 Overview of Geochemical Proxies........................................................................... 21

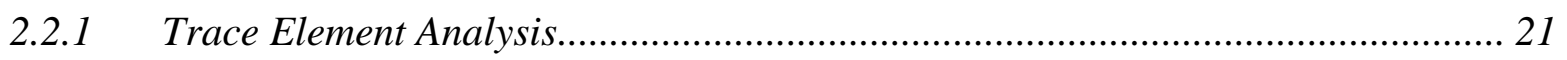

2.2.2 Clay Mineralogy ................................................................................................. 23

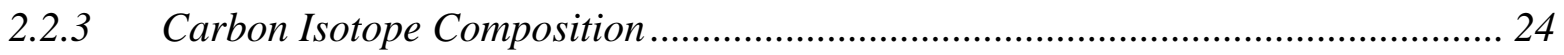

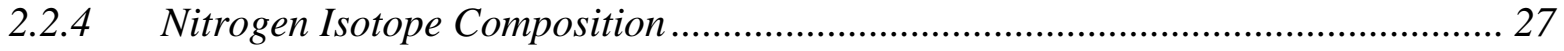

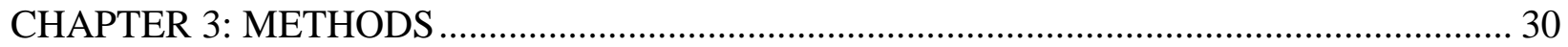

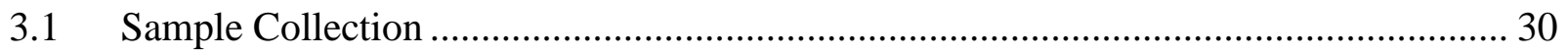

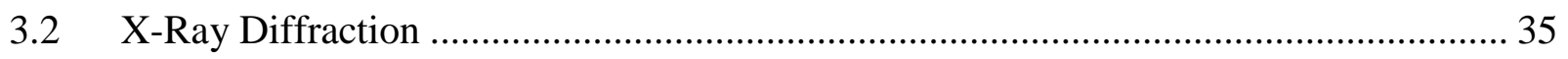

3.3 Organic Carbon and Nitrogen Stable Isotope Analysis ............................................ 37

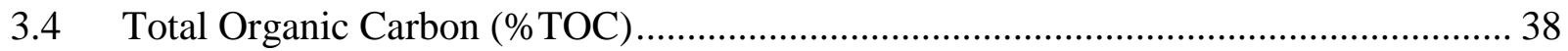

3.5 Inductively Coupled Plasma Mass Spectroscopy (ICP-MS)..................................... 38

3.6 Statistical Analyses of Volcanic Ash Beds and Crow Creek Member ....................... 38

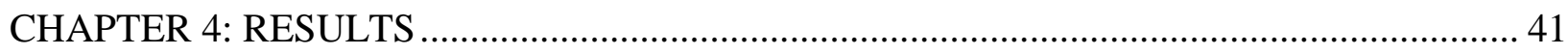

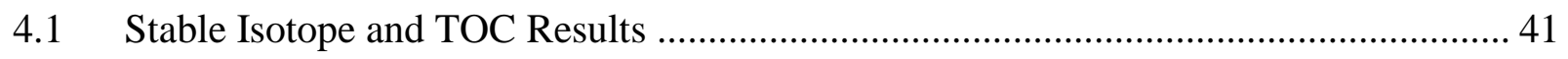

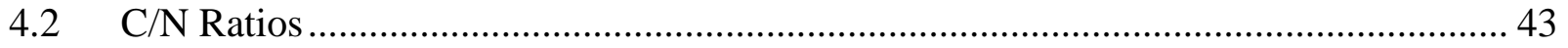

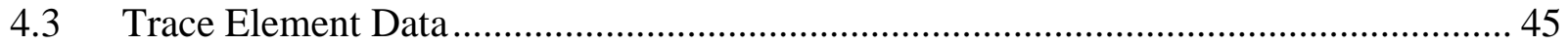

4.4 Volcanic Ash Geochemical Trends and Statistical Analyses................................... 49

4.4.1 Volcanic Ash Stable Isotope, TOC, and C/N Scatter Plots.................................. 49

4.4.2 Volcanic Ash Trace Element Scatter Plots ......................................................... 51

4.4.3 Volcanic Ash Statistical Analyses ....................................................................... 54

4.5 Crow Creek Geochemical Trends and Statistical Analysis....................................... 55 
4.5.1 Crow Creek Member Stable Isotope, TOC, and C/N Scatter Plots ...................... 55

4.5.2 Crow Creek Trace Element Scatter Plots .......................................................... 57

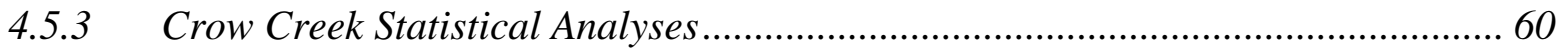

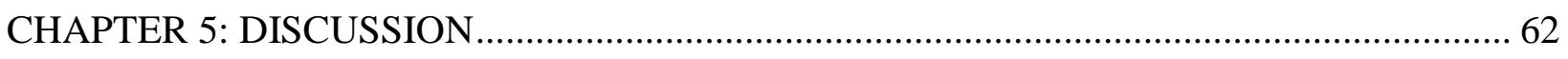

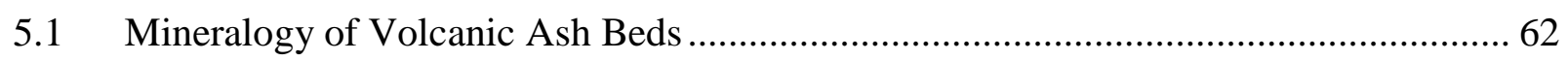

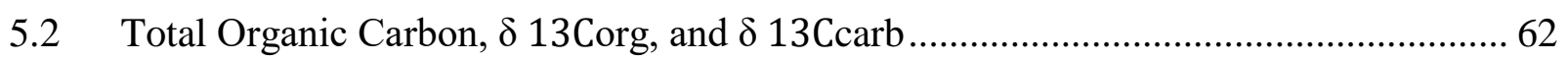

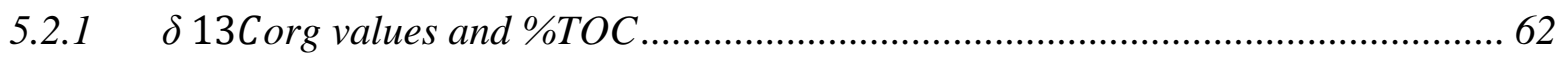

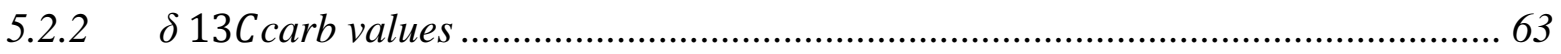

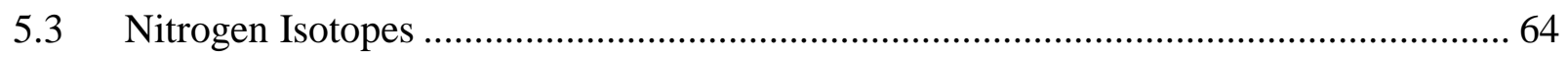

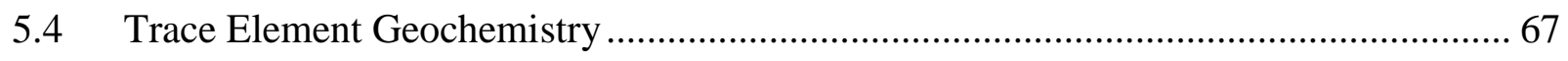

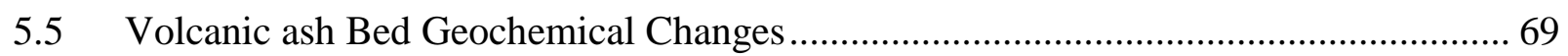

5.6 Crow Creek Geochemical Changes........................................................................... 70

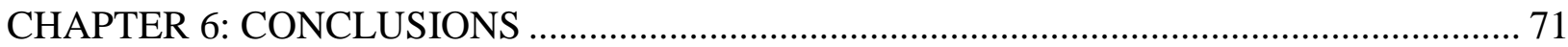

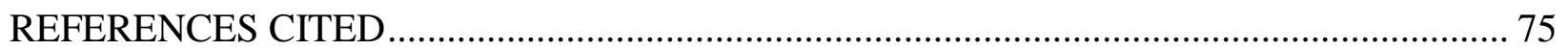




\section{LIST OF TABLES}

1. Treedam Core Stratigraphic Depths and Lithology Description.......................13

2. Geochemical Proxies Used to Interpret Clastic Input and Marine Redox Conditions.....27

3. Treedam Volcanic Ash Samples............................................41

4. Volcanic Ash T and Z Score Values.........................................60

5. Crow Creek Member T and Z Score Values.....................................61 


\section{LIST OF FIGURES}

1. Stratigraphy of the Pierre Shale in Study Area...............................................................

2. Location of Treedam Core in relation to Manson Impact Site and Volcanically Active Sites During the Late Campanian................................................................................10

3. Sr/Sr Dating of the Pierre Shale in Study Area and Sedimentation Rate Calculations.....17

4. Diagram of Volcanic Impact on Marine Redox Conditions............................................20

5. Treedam Core Depth Sampled for Volcanic Ash B1 at 77.2 feet (23.53 meters)

6. Treedam Core Depth Sampled for Volcanic Ash B2 at 122.5 feet (37.33 meters)

7. Treedam Core Depth Sampled for Volcanic Ash B3 at 299.08 feet (91.15

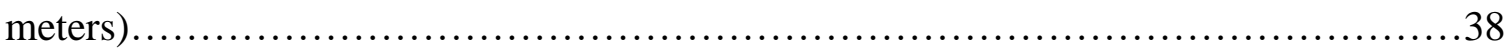

8. Treedam Core Depth Sampled for Volcanic Ash B4 at 299.21 feet (199.19

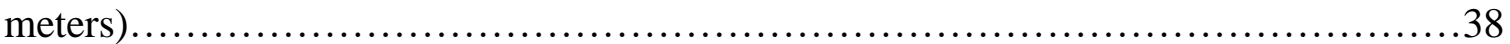

9. Treedam Core Depth Sampled for Volcanic Ash B5 at 307.1 feet $(93.60$ meters)

10. Treedam Core Depth Sampled for Volcanic Ash B6 at 307.75 feet $(93.80$ meters)

11. Treedam Core Depth Sampled for Volcanic Ash B7 at 499.3 feet (152.18 meters)

12. X-Ray Diffraction Patterns for Ash Bed Samples...................................42

13. Carbon and Nitrogen Stable Isotope Data for the Treedam Core .......................47

14. Carbon and Nitrogen Weight Percent Data for the Treedam Core......................49 
15. Trace Element Sedimentation Proxy Data for the Treedam Core.

16. Trace Element Redox Proxy Data for the Treedam Core.............................53

17. Ash Bed Stable Isotope Scatter Plots........................................55

18. Ash Bed Trace Element Clastic Input Proxy Scatter Plots..........................59

19. Ash Bed Trace Element Redox Proxy Scatter Plots................................60

20. Crow Creek Member Stable Isotope Scatter Plots................................62

21. Crow Creek Member Trace Element Proxy Scatter Plots............................65 


\section{CHAPTER 1: INTRODUCTION}

The Pierre Shale is an organic-rich shale from the Late Cretaceous Period (Campanian and Maastrichtian stages) spanning from Canada and Montana through South Dakota and Colorado, extending as far south as New Mexico (Encyclopedia Britannica, 2015; Patrick et al., 2004). The Pierre Shale Group was deposited in a shallow marine foreland basin called the Western Interior Seaway, which contains many Cretaceous marine fossils (Bertog et al., 2007; Hanczaryk and Gallagher, 2007; Martin et al., 2007; Patrick et al, 2004). Early Campanian fluvial input to the Cretaceous Interior Seaway decreased salinity and caused an influx of terrigenous nutrients (Nicholls, 1989). Basin restriction, combined with early Campanian nutrient influx from rivers, resulted in bottom water anoxia and eutrophication and carbonatepoor mud during the deposition of the Sharon Springs Member, the basal unit of the Pierre Shale (Martin et al., 2007; Nicholls, 1989). The Pierre Shale consists of organic-rich marine claystone that contains smectite and illite clays (Garavito, Kooi, and Neuzil, 2006; Crandell, 1958). The upper Members of the Pierre Shale (Figure 1) were deposited during the cooling of the Late Campanian age, during which the climate changed and marine productivity was dependent on solar and volcanic activity (Zakharov, et al., 2013).

The Pierre Shale and the underlying Niobrara Formation are recognized as productive shale gas plays in some areas of the United States, such as Colorado and Nebraska. In Colorado, Pierre Shale wells produced a total of 2 million cubic feet (56,640 million cubic meters) of gas per day in 2008 (Brathwaite, 2009). In spite of the hydrocarbon potential of these formations and members, assessment for hydrocarbon generation and thermal maturity has not been wellexplored in many areas containing the Pierre Shale and the Niobrara. The exploration of these 


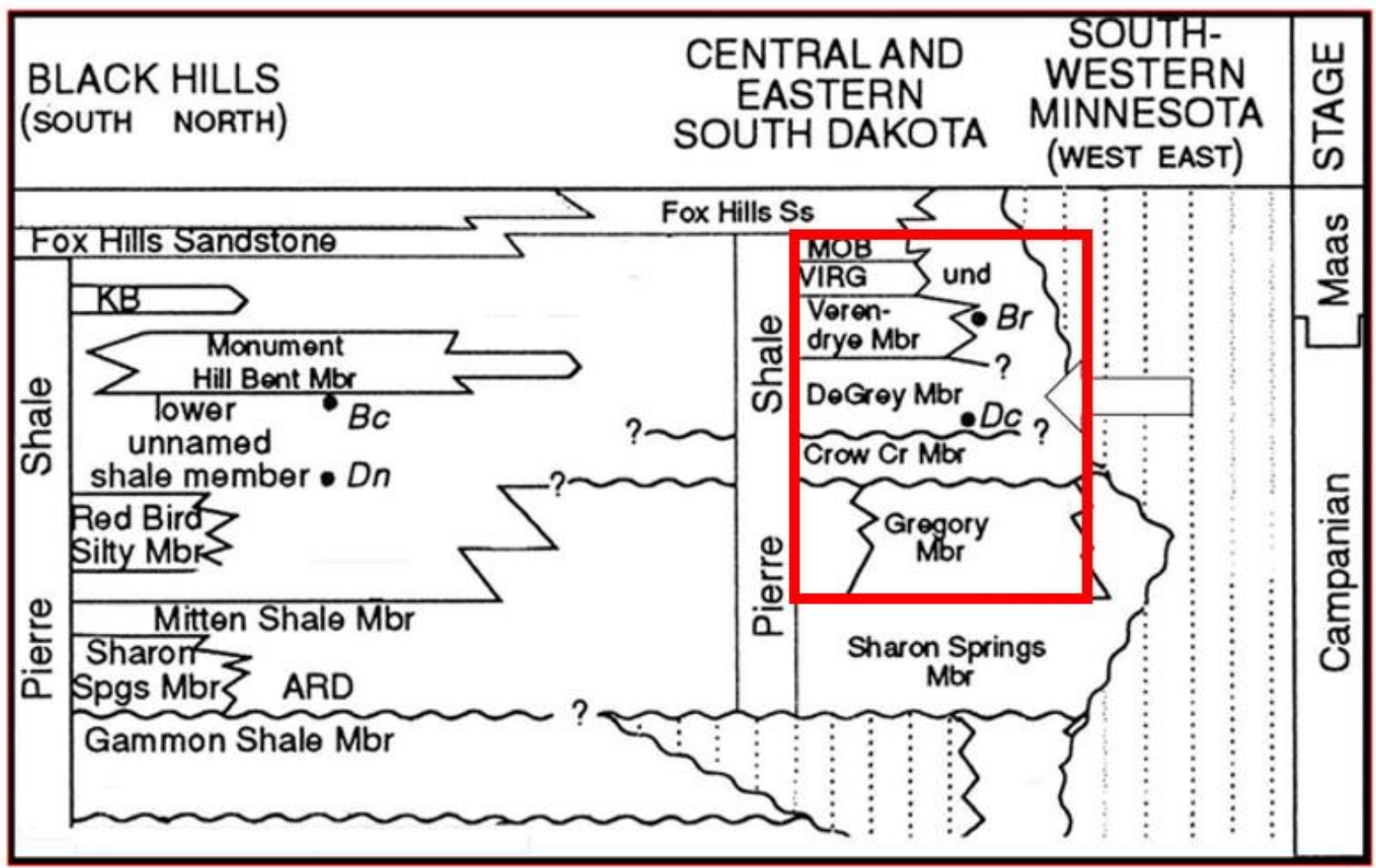

Figure 1: The area beneath "Central and Eastern South Dakota" represents the general stratigraphy of the Pierre Shale in the study area (modified from Fox, 2007).

formations could aid in identifying shallow hydrocarbon plays in under-explored areas such as South Dakota. Pierre Shale organic carbon content, thermal maturity, and preservation can be assessed by studying regional marine geochemical history as well as changes in the depositional environment through time. Although many studies have examined paleoenvironment in Cretaceous marine shales, limited research has been done to examine the paleoenvironment and paleoredox record of the Pierre Shale in South Dakota. Analysis of carbon and nitrogen isotopes combined with source rock analysis and trace elemental analysis of the Pierre Shale would improve understanding of marine geochemistry and paleoenvironmental changes over time. This knowledge would be helpful for interpreting the geochemical and redox history of coastal environments of the Western Interior Seaway. These geochemical records could also provide information on areas with hydrocarbon production potential. 
Hydrocarbon potential has been explored by studying paleoenvironment (environment during deposition) and paleo-marine redox (oxidation/reduction of marine environment during deposition) conditions during the Late Cretaceous Period (Locklair et al., 2010; Patrick et al., 2004; Meyers, 1992; Dean et al., 1984). Isotopic and trace element geochemical methods were used in many of these studies to identify periods of anoxia in Cretaceous marine environments during which enhanced organic carbon burial and preservation has been observed (e.g. Corbett and Watkins, 2013; Locklair et al., 2010; Leckie et al., 2002). Intermittent marine anoxia was a common occurrence in Cretaceous marine settings. Major periods of marine anoxia have been given the term Oceanic Anoxic Events (OAEs) (Wang et al., 2013; Locklair et al., 2010; Meyer and Kump, 2008; Patrick et al., 2004; Leckie et al., 2002; Wignall and Twitchett, 1996). High rates of organic deposition created by slowing ocean circulation, limited ocean mixing, increases in global temperatures, and increases in greenhouse gases such as those generated by increased volcanism are potential causes of OAEs (Meyer and Kump, 2008; Leckie et al., 2002; Wignall and Twitchett, 1996).

Paleoenvironmental studies and paleo-redox proxies can provide information on the member's depositional history as well as the effects this depositional event may have had on the marine ecosystem. The Crow Creek Member is thought to have been deposited by a tsunami generated by the Manson impact in Iowa 74 million years ago (Weber and Watkins, 2007; Katongo et al., 2004; Izett et al., 1998). Iowa was at that time part of the Western Interior Seaway Eastern shoreline. The Crow Creek Member is recognized as a thick layer of unconsolidated, coarse sand which contains impact ejecta, shocked grains, and rip-up clasts (Izett et al., 1998). In spite of this member's significant effect on the surrounding depositional environment, there are no known geochemical studies investigating the effects of the Manson 
impact on regional marine geochemistry. A geochemical and stable isotope record of the Pierre Shale would provide information on geochemical and paleoproductivity changes related to the Manson impact.

In addition to the Manson impact depositional event, the Pierre Shale can be characterized by its abundance of volcanic ash beds. There were numerous active volcanic centers relative to the Pierre Shale study area in the late Campanian age (shown in Figure 2) and the most active volcanic centers were the Elkhorn Mountain Volcanics in western Montana (Bertog et al., 2007). These centers and others created by the Farallon plate subducting beneath the North American plate are the most likely sources for the volcanic ash beds found in the Pierre Shale (Bertog et al., 2007).

Enhanced volcanism and ash deposition may have had a major impact on redox conditions, organic matter deposition, and preservation of organic matter. In some cases, ash deposition in aquatic environments has been shown to provide a major source of nutrients in modern marine settings, resulting in an increase in marine productivity, resulting in an increase in organic matter deposition and preservation (Shen et al., 2013; Kockum et al., 2006; Felitsyn and Kirianov, 2001). Similar productivity blooms could have happened during Pierre Shale deposition, leading to high amounts of organic carbon deposition and preservation. 


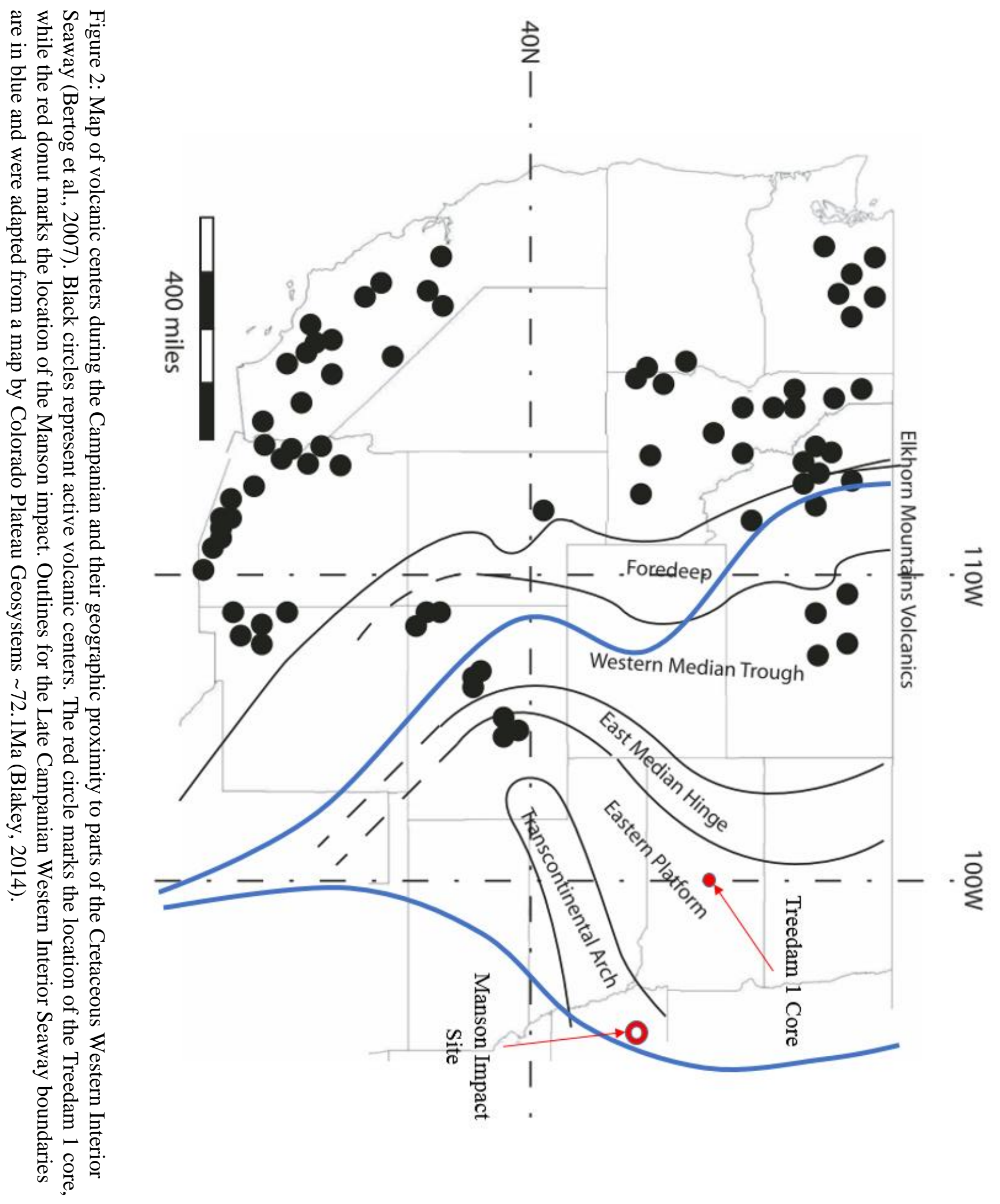


Many volcanic ash layers preserved in marine sediment can be found throughout the Pierre Shale (Bertog et al., 2007; Hanczaryk and Gallagher, 2007; Patrick et al., 2004). The influx of ash from frequent Late Campanian volcanic eruptions may have contributed to increased marine productivity by leaching nutrients necessary for photosynthesis into the water column (Jones and Gislason, 2008; Kockum et al., 2006; Felitsyn and Kirianov; 2001). In order to understand how these volcanic events affected the marine geochemistry of the Late Cretaceous Pierre Shale, higher resolution paleoredox and paleoproductivity records are needed.

A core of the Pierre Shale called the Treedam core was drilled near Fort Pierre, South Dakota by the South Dakota School of Mines and Technology. This drilling effort was in part meant to expand research on the Pierre Shale and Niobrara Chalk. The Treedam core includes the Virgin Creek, Verendrye, DeGrey, Crow Creek, and Gregory Members of the Pierre Shale (see Figure 1). Access to the Treedam core provides an excellent opportunity to establish additional geochemical and stable isotope records of the Pierre Shale in South Dakota. Carbon and nitrogen stable isotope records and geochemistry derived from samples the Treedam core can help define the South Dakota Cretaceous paleoenvironment with minimal alteration from external weathering. Stable isotope, total organic carbon, and trace element geochemical records can also help identify periods of oscillating redox conditions and areas of high organic carbon content (Meyer and Kump, 2008; Leckie et al., 2002; Wignall and Twitchett, 1996). The highresolution isotope and geochemical characterization of the Pierre Shale could also help in the local and regional correlation of stratigraphic units across other Pierre Shale localities in the basin.

The focus of this study is to examine the paleoenvironmental and paleoredox history of the Pierre Shale with special emphasis on how the Manson impact and subsequent ash deposition 
affected paleoredox conditions in the Western Interior Seaway. There is very little information about the exact source of each of these volcanic ash beds, which were deposited above the Crow Creek Member. Studies examining ash beds from the Sharon Springs Member of the Pierre and the Upper Niobrara formation show that the majority of these ash deposits in the Western Interior Seaway originated from the Elkhorn Mountain Volcanics in Montana (the backarc basin) and the Cascade Mountains (the forearc basin) (Bertog, 2013; Bertog et al., 2007). The approach included trace element, total organic carbon, and carbon and nitrogen isotope analysis of rock samples collected from the Treedam core.

\subsection{South Dakota Stratigraphy}

The Pierre Shale Group sits above the Niobrara and underneath the Hell Creek formation (Crandell, 1958). Near Fort Pierre, South Dakota, the Pierre Shale is typically a dark gray color and can be found interbedded with sandstone and ash. Fossils and iron magnesium concretions are also present in this shale (Hanczaryk and Gallagher, 2007; Patrick et al., 2004; Crandell, 1958). The Pierre Shale Group is divided up into eight members (Martin et al., 2007; Patrick et al., 2004). All Pierre Shale members from oldest to youngest are Sharon Springs, Gregory, Crow Creek (as a lower member of the DeGrey), DeGrey, Verendrye, Virgin Creek, Mobridge, and Elk Butte. The Sharon Springs, Modbridge, and Elk Butte formations are not included in this study because they were not present in the available Treedam core samples. 


\subsubsection{Pierre Shale Stratigraphy}

\section{RESPEC Treedam Core Stratigraphic Units}

\begin{tabular}{|c|c|c|}
\hline $\begin{array}{l}\text { Treedam } \\
\text { Depth (ft) }\end{array}$ & $\begin{array}{l}\text { Member of Pierre } \\
\text { Shale }\end{array}$ & Description \\
\hline $0-20$ & Glacial Sediment & $\begin{array}{l}\text { Soil, clay and clayey sand (thought to be reworked sand from the } \\
\text { terrace deposits on top of Standing Butte or possibly glacial } \\
\text { outwash [the drill site is near the estimated maximum extent of } \\
\text { glaciation]). }\end{array}$ \\
\hline $20^{\prime}-140^{\prime}$ & Virgin Creek, upper & Mostly mudstone and claystone, some limestone concretions. \\
\hline $140^{\prime}-170^{\prime}$ & Virgin Creek, lower & Mostly shale, ash beds. \\
\hline $170^{\prime}-325^{\prime}$ & Verendrye & $\begin{array}{l}\text { Mostly claystone and mudstone, massive appearance, } \\
\text { iron/phosphate concretions. }\end{array}$ \\
\hline $325^{\prime}-386^{\prime}$ & $\begin{array}{l}\text { DeGrey, upper } \\
\text { shale, and ash } \\
\text { facies }\end{array}$ & Volcanic ash beds, few iron/phosphate concretions. \\
\hline $386^{\prime}-452^{\prime}$ & DeGrey, lower & Siliceous shale facies and claystone, fewer ash beds. \\
\hline $452^{\prime}-455^{\prime}$ & $\begin{array}{l}\text { Crow Creek } \\
\text { Member of DeGrey }\end{array}$ & $\begin{array}{l}\text { Medium to coarse grained sand, unconsolidated, contains shale } \\
\text { rip-up clasts, unconformable above and below (upper marl unit is } \\
\text { missing which is often described as gradational with the overlying } \\
\text { DeGrey). }\end{array}$ \\
\hline $455^{\prime}-512{ }^{\prime}$ & Gregory & $\begin{array}{l}\text { Shale and claystone with beds of marl and LS, siltstone-to-fine } \\
\text { sand beds at } 480 \text { ' and } 502 \text { '. }\end{array}$ \\
\hline
\end{tabular}

Table 1: Treedam core stratigraphic depths and lithology description.

The members of the Pierre Shale Group included in the study of the Treedam core include the Virgin Creek, Verendrye, DeGrey, Crow Creek, and Gregory Members (Table 1). The stratigraphic contacts in the Treedam core were established by RESPEC in South Dakota.

The upper 60 feet (18.29 meters) of the Gregory Member is present between the depths of 455-512 feet (138.68-156.05 meters) in the Treedam core. The Gregory is characterized in the lithologs as shale and claystone with beds of marl and limestone. Siltstone-to-fine sand beds occur at 480 and 502 feet (146.30-153.01 meters). This characterization is in line with the 
classification of the Gregory as olive gray claystone characterized by interbedded calcareous and non-calcareous marl, shale, and limestone (Hanczaryk and Gallagher, 2007; Crandell, 1950).

The DeGrey and Crow Creek units combined in the Treedam core are 130 feet thick (39.62 meters). The Crow Creek is of particular interest because there are different theories for its depositional source. Some researchers state that the Crow Creek marks the beginning of the Bearpaw transgressive cycle which occurred independently of the Manson impact (Varricchio et al., 2009; Hanczaryk and Gallagher, 2007; Weber and Watkins, 2007; Katongo et al., 2004; Izett, 1998). It is possible that localized uplift events nearby caused the Carlile Shale and Codell Sandstone Member to become eroded and deposited as the Crow Creek Member (Hanczaryk and Gallagher, 2007).

Others hypothesize that this member was deposited by a tsunami generated by the Manson impact in Iowa (Hanczaryk and Gallagher, 2007; Weber and Watkins, 2007; Katongo et al., 2004; Izett, 1998). Evidence for the tsunami hypothesis includes coarse grains at the base of the member in a fining upward sequence, the presence of rip-up clasts, and a sharp contact with the underlying Gregory Member (Hanczaryk and Gallagher, 2007; Weber and Watkins, 2007; Katongo et al., 2004; Izett, 1998). Evidence is further supported by the presence of shocked minerals and impact ejecta (Weber and Watkins, 2007; Katongo et al., 2004; Izett, 1998).

The Crow Creek unit spans from a 452-455 feet (137.77-138.68 meters) depth in the Treedam core. It is a small member (about 3 feet $(1 \mathrm{~m})$ thick in the Treedam study area) and is considered by some authors to be a part of the overlying DeGrey Member (Hanczaryk and Gallagher, 2007; Martin et al., 2007). Within the core, the Crow Creek is classified as a medium to coarse-grained unconsolidated sand and is often identified by shale rip-up clasts. The Crow Creek Member only occurs in South Dakota and Nebraska and is typically composed of 
calcareous sandy siltstone, or marl in other locations (Hanczaryk and Gallagher, 2007; Crandell, 1958).

The DeGrey Member occurs from depths of 325-452 feet (99.06-137.77 meters) in the core. The base of the DeGrey is composed of ash beds and is non-calcareous with iron manganese concretions (Hanczaryk and Gallagher, 2007; Crandell, 1958).

The Verendrye was described by Hanczaryk and Gallagher (2007) from outcrops along the Missouri River as massive claystone and mudstone with iron or phosphate concretions and popcorn weathering texture. The lithology of the Verendrye is a light olive to brownish-gray shale and claystone (Hanczaryk and Gallagher, 2007; Crandell, 1958). The Verendrye Member (around 155 feet thick/47.24 meters) overlies the DeGrey with a gradational basal contact, which can be distinguished by ammonite shell fragments (Hanczaryk and Gallagher, 2007; Crandell, 1958). In the Treedam core, the Verendrye is between the depths of 170 and 325 feet (51.8199.06 meters).

The topmost unit in the Treedam core is the Virgin Creek Member with a thickness of about 150 feet (45.72 meters). The Virgin Creek in the core extends from 20 feet to 170 feet (6.09-51.81 meters). The upper section from 20-140 feet (6.09-42.67 meters) is classified as mud or claystone with some limestone concretions, whereas the lithology in the lower section from 140-170 feet (42.67-51.81 meters) changes to shale and ash beds. The Virgin Creek Member is known to have an olive to brownish-gray color and contains baculite fossils (Stoffer, 1998; Crandall, 1958). 


\subsection{Pierre Shale Depositional Environment}

The Pierre Shale in the Treedam locality was deposited over the course of about 12.6 million years according to sedimentation rate calculations from other studies done on the Pierre Shale in central South Dakota. This averages to 2,100 years per inch $(2.5 \mathrm{~cm})$ of sediment (Hanczaryk and Gallagher, 2007; Patrick et al., 2004). During the time of deposition, several changes took place in the environment of the Western Interior Seaway. The sharp contact between the Gregory Member and the Crow Creek Member, along with faunal changes across the unconformity, showed a change from a deeper marine environment to a very shallow marine environment (Hanczaryk and Gallagher, 2007). The Gregory was likely deposited in a regressive environment caused by the Claggett Cyclothem, shifting to a high energy transgressive environment in the Crow Creek, caused by the Bearpaw Cyclothem (Hanczaryk and Gallagher, 2007). In some localities there is carbonate deposited at the top of the Crow Creek Member, indicating shallow warm marine conditions (Hanczaryk and Gallagher, 2007). The DeGrey and Verendrye were both deposited under deeper marine environments during the Bearpaw transgression (Hanczaryk and Gallagher, 2007).

A highstand systems tract (HST) dominates the Gregory Member (shown in Figure 3) and indicates shallowing marine conditions over time (Hanczaryk and Gallagher, 2007). The Crow Creek and the DeGrey are part of a transgressive systems tract (TST) due to the Bearpaw Cyclothem, indicating a rising sea level (shown in Figure 3) (Hanczaryk and Gallagher, 2007). A maximum flooding surface (MFS) occurs at the contact between the DeGrey and Verendrye, and another speculated towards the top of the Gregory (shown in Figure 3) (Hanczaryk and Gallagher, 2007). The maximum flooding surface sand layer in the Gregory is named the Fort 
Thompson bed. The Fort Thompson bed exhibits cross-stratification and was likely deposited by storms (Hanczaryk and Gallagher, 2007).

Sediment accumulation was much lower during the DeGrey and Verendrye Members $(\sim 1.16 \mathrm{~cm} / 1000$ years) than it was in the Gregory and Crow Creek Members $(\sim 2.72 \mathrm{~cm} / 1000$ years; See figure 3) (Hanczaryk and Gallagher, 2007). Marine conditions were found to have been dysaerobic to anoxic throughout the deposition of the Pierre Shale, with the exception of the Crow Creek and Fort Thompson strata which were deposited in shallow, warm, oxic marine conditions (Hanczaryk and Gallagher, 2007).

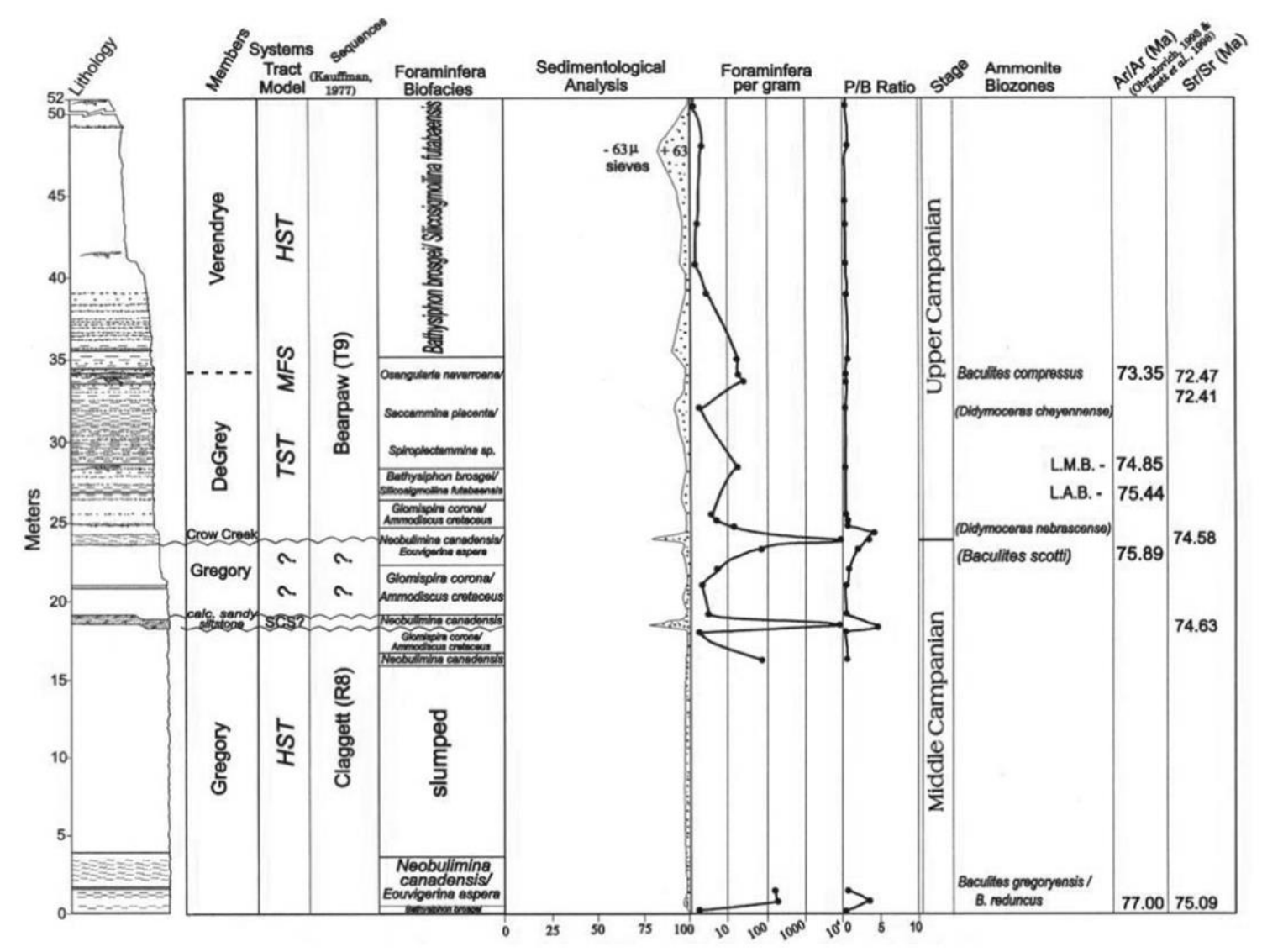

Figure 3: Stratigraphy of the Pierre Shale in the Treedam study area was age dated using $\mathrm{Sr} / \mathrm{Sr}$ dating by Hanczaryk and Gallagher (Figure modified from Hanczaryk and Gallagher, 2007). Relative ages for each member are shown for both $\mathrm{Ar} / \mathrm{Ar}$ dating and $\mathrm{Sr} / \mathrm{Sr}$ dating. More accurate sedimentation rates can be calculated for the Treedam core based on these dates. The average sedimentation rate is $\sim 1.2 \mathrm{~cm} / 1000$ years according to a study by Patrick et al. (2007). 


\subsection{Volcanic Effects on Productivity, Redox Conditions, and Organic Matter Preservation}

The ash from nearby volcanic eruptions during the Late Campanian would have been deposited as layers of fine-grained clay and silica. The volcanic ash deposition related to these events could have affected the Cretaceous marine environments.

Rare earth elements can be released by volcanic ash into the water column, and in some cases provide nutrients and increase marine productivity rates (Thompson et al., 2012;

Langmann et al., 2010; Schacht et al. 2010; Jones and Gislason, 2008). Therefore, over the long term, ash deposition has been found to increase marine productivity by increasing the aquatic nutrient supply for marine biota (Shen et al., 2013; Langmann et al., 2010; Felitsyn and Kirianov, 2001). Elements that are essential for high rates of productivity include iron and phosphorous ash in aqueous environments, and these elements were shown to leech from ash into the water column (Shen et al., 2013; Thompson et al., 2012; Flaathen and Gislason, 2007). A separate study performed by Croot, Schacht, and Hoffmann showed that chlorophyll- $a$ (present in marine algae) noticeably increases within hours after ash deposition, indicating an increase in photosynthesis $(2010 ; 2007)$. These findings indicate that volcanic ash can be linked with increases in productivity on a shorter time scale. These studies lend evidence to suggest that volcanic activity may have increased rates of productivity in the Western Interior Seaway throughout the Cretaceous period.

Recent studies have also highlighted the effects of volcanic ash deposition on redox conditions (Shen et al., 2013; Shen et al., 2012; Thompson et al., 2012; Langmann et al., 2010; Schacht et al., 2010; Jones and Gislason, 2008; Meyer and Kump, 2008; Kockum et al., 2006). Meyer and Kump hypothesized that volcanically-generated atmospheric $\mathrm{CO}_{2}$ can be a major 
trigger for anoxia, as can be seen in Figure 4. In this positive feedback loop, increased input of volcanic ash and gases into the atmosphere contributes to the global increase in atmospheric $\mathrm{pCO}_{2}$ and results in warmer climates. Increases in global temperatures decrease oxygen solubility in deep water marine environments (Meyer and Kump, 2008). Warmer climates also cause changes in precipitation, resulting in higher rates of nutrient input by mechanical weathering (Meyer and Kump, 2008). Increased productivity, paired with a decrease in oxygen transport to deeper marine waters, can result in high rates of organic matter deposition with enhanced organic 


\section{Climate}

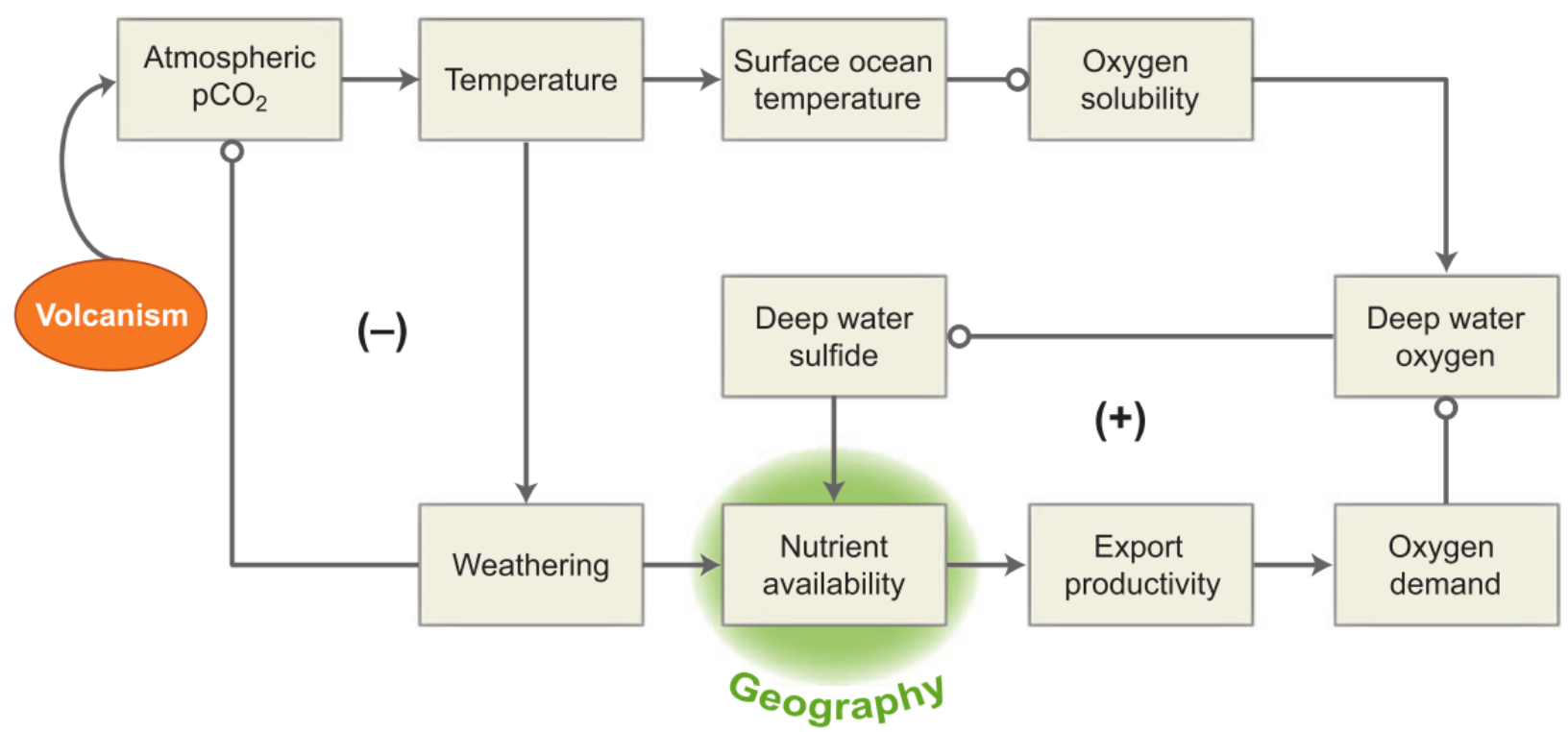

Figure 4: Model of a feedback loops resulting in marine anoxia (modified after Meyer and Kump, 2008). Normal arrows indicate same direction environmental response, while lines ending in an open circle indicate responses in the opposite direction. Enhanced volcanism increases $\mathrm{CO}_{2}$ in the atmosphere causing global warming. Increased atmospheric temperatures result in increased precipitation, causing weathering and nutrient transport into aquatic environments. Increased temperatures also decrease oxygen content in aquatic environments. Increased nutrients combined with increased oxygen result in sulfate reduction and an anoxic/euxinic environment. The resulting mobilization of dissolved Fe and $\mathrm{P}$ from marine sediment causes a positive feedback loop in which more nutrients are added resulting in more sulfate reduction. The only way the cycle stops is when volcanism declines and the $\mathrm{CO} 2$ input is decreased

preservation in these marine systems (Meyer and Kump, 2008; Leckie et al., 2002). Anoxic conditions may continue until volcanic activity subsides and reduces $\mathrm{CO}_{2}$ content in the atmosphere (Meyer and Kump, 2008).

A few studies have also shown that volcanic ash can cause harm to marine plankton communities and decrease productivity by increasing marine turbidity, causing ocean surface water acidification, and introducing poisonous lead $(\mathrm{Pb})$ and mercury $(\mathrm{Hg})$ into the surface waters (Shen et al., 2013; Shen et al., 2012; Thompson et al., 2012; Langmann et al., 2010; 
Schacht et al., 2010; Jones and Gislason, 2008). Kockum et al. (2005) have stated that aluminum released from volcanic ash can produce a toxic effect in poorly-circulated closed aqueous environments, such as lakes and restricted seas. Ocean acidification caused by large amounts of fluorine and other metals released from volcanic ash, in addition to ocean acidification resulting from the influx of $\mathrm{CO}_{2}$ in the atmosphere can have a severe impact on aquatic ecosystems; however, this effect can be countered in larger marine environements because seawater has a lower aluminum concentration and greater proton buffering ability than freshwater bodies (Kockum et al., 2006). Proton buffering in marine environments regulates environmental stresses and toxicity effects, which are otherwise catastrophic in smaller bodies of water such as lakes (Kockum et al., 2006). This research implies that volcanic ash deposition may leach metals into marine surface waters immediately after volcanic events, but that the impact of ash deposition on water chemistry depends on water depth and water mixing. In the case of the Western Interior Seaway, it is unclear how volcanic ash and $\mathrm{CO}_{2}$ may have affected marine environments.

While there is plenty of work showing how episodes of ash deposition can impact aquatic life and redox conditions, there is little published literature on how ash deposition in marine environments could have potentially affected the geochemical and/or carbon/nitrogen stable isotope signatures of marine sediments. These proxies for productivity and redox conditions could provide information on changes in marine geochemistry and whether or not these changes were influenced by the deposition of volcanic ash. This work investigated the geochemical and isotopic composition of sediments deposited before, during, and after the volcanic events (recorded in the form of ash layers) in the Pierre Shale. 


\subsection{Research Objectives and Hypotheses}

\subsubsection{Objective 1:}

The first objective of this research project was to investigate temporal changes in geochemical parameters after volcanic ash deposition.

\section{Hypothesis 1:}

We hypothesize that ash deposition in the Pierre Shale provided nutrients for primary production, resulting in a geochemical record of higher productivity in the overlying zone. Light carbon and light nitrogen will have been consumed by primary producers and $\delta^{13} \mathrm{C}$ and $\delta^{15} \mathrm{~N}$ will have become enriched in layers above the ash. Trace element concentration will have increased in the sediment post-ash deposition due to the leaching of trace elements into the water column.

\section{Approach 1:}

Volcanic ash beds from the Treedam core were sampled immediately below, within, and above seven ash layers chosen throughout the core. Other samples were taken throughout the core every few feet to provide background values for comparison. X-ray diffraction was used to confirm the presence of the swelling clay montmorillonite to verify that the ash layers were actually volcanic ash deposits, and not simply stained or discolored shale. All samples were analyzed for TOC content, carbon and nitrogen stable isotope values, and trace element proxies. These geochemical proxies were used to examine trends and relationships between ash deposition and changes in marine redox chemistry and productivity via $t$ and $z$ statistics. Effects of ash on marine geochemistry were judged by statistically significant divergence of ash geochemistry from overall geochemical values in the Treedam core. 


\subsubsection{Objective 2:}

Examine temporal changes in geochemical parameters to understand the origin of the Crow Creek Member and the changes in geochemical parameters after Crow Creek Member deposition.

\section{Hypothesis 2:}

The geochemical trends associated with the Crow Creek were investigated for evidence that it was deposited by the Manson impact. We hypothesize that the Crow Creek depositional event may have caused increased marine turbidity, which should have led to decreased productivity caused by a lower rate of photosynthesis among primary producers. We hypothesize that lower rates of photosynthesis will have resulted in the death of primary producers and their deposition in bottom sediments as organic carbon. The eventual decomposition of these large amounts of organic matter resulted in a consumption of bottom water oxygen contributing to bottom water suboxic/anoxic conditions that preserved the remaining organic carbon.

\section{Approach 2:}

To test this hypotheses, geochemical proxies such as $\delta^{15} \mathrm{~N}, \delta^{13} \mathrm{C}, \% \mathrm{TOC}$, and trace elements were used to reconstruct paleoredox and paleoproductivity changes caused by volcanic ash and Crow Creek Member deposition. Lower rates of photosynthesis and rapid burial of organic carbon would have resulted in a negative shift in both carbon and nitrogen stable isotope ratios. Total organic carbon content increased within the sediment due to deposition and preservation of organic matter, and trace element content increased above Crow Creek Member deposition due to increases in anoxic conditions. $\mathrm{T}$ and $\mathrm{Z}$-statistics were used to judge if effects of the Crow Creek depositional event on marine geochemistry are statistically significant. 


\section{CHAPTER 2: LITERATURE REVIEW}

\subsection{Overview of Shale Formation and Organic Matter Preservation}

While preservation, production, and supply of organic matter are considered to be the major factors controlling accumulation of organic matter in marine environments, there is still debate over which factor has the more dominant control over organic-rich shale formation in marine sediments (Murphy et al., 2000; Aller, 1994; Demaison and Moore, 1980). Organic matter preservation depends on many factors, such as water column redox conditions, bioturbation, sedimentation rates, water depth, and type of organic matter deposited (Aller, 1994; Stein, 1991; Demaison and Moore, 1980).

According to the preservation model, pre-existing anoxic bottom conditions, often in deep-water marine environments, result in enhanced organic preservation (Demaison and Moore, 1980). Sea surface temperatures and atmospheric partial pressure of carbon dioxide $\left(\mathrm{pCO}_{2}\right)$ can play a major role in controlling marine redox conditions (Hinga, et al., 1994; Meyers, 1992). Poor circulation in the water column can cause anoxia by reducing oxygen cycling in the water column, resulting in a layer of water with low oxygen content, also known as the oxygen minimum zone (Corbett and Watkins, 2013; Shen et al., 2013; Shen et al., 2012; Meyer and Kump, 2000; Stein, 1991). Higher surface temperatures lead to lower dissolved oxygen in the water column, which then reduces oxygen transport to deeper water (Meyer and Kump, 2008). Higher temperatures can also contribute to higher weathering rates, sedimentation, and an increase in surface nutrients such as phosphate, which have been shown to cause increased marine productivity, and greater demand for dissolved oxygen in deep water (Meyer and Kump, 2008). Without oceanic mixing, oxygen is not available for organic matter degradation, resulting 
in higher rates of preservation (Meyer and Kump, 2008; Stein, 1991; Demaison and Moore, 1980). Some argue that the preservation model is the more important factor that causes low marine oxygen conditions, and that organic matter is best preserved in conditions of complete marine anoxia and/or euxinia (Jarvis et al., 2011; Demaison and Moore, 1980).

The production model, on the other hand, states that low marine oxygn conditions are caused by increasing marine productivity, often in shallow environments with hypoxia or seasonal anoxia, leading to changes in oxygen-rich water distribution (Jarvis et al., 2011; Stein, 1991; Demaison and Moore, 1980). Algal blooms have been found to contribute biogenic carbon to the bottom waters as well as increase the demand for marine oxygen-rich water (Stein, 1991; Demaison and Moore, 1980). Depending on the water's salinity, temperature, and oxygen content, oxygen-rich surface water may not be dense enough to sink to the oxygen-depleted marine zone, resulting in insufficient oxygen transport (Demaison and Moore, 1980). Decomposition of organic matter in benthic marine environments also creates a demand for oxygen (Demaison and Moore, 1980). High productivity, high organic matter decomposition, and low oxygen oceanic mixing produce anoxic marine environments (Demaison and Moore, 1980). Marine autotrophs consume atmospheric $\mathrm{CO}_{2}$ by photosynthesis, then they convert to organic carbon and major portion of this carbon gets re-oxidized and returns to the atmosphere while a small fraction is deposited in the form of organic carbon (Galy et al., 2007).

In addition to productivity and redox conditions, sediment accumulation rates can also play an important role. Greater amounts of sediment accumulate in marine shelf environments, due to increased surface productivity rates and closer proximity to the shoreline (Stein, 1991). Most organic matter decays as it sinks in the water column, and even after deposition the organics can continue diagenesis (Stein, 1991; Demaison and Moore, 1980). Some organic 
matter reaches the sea floor; however, it is a small percentage of the original organic matter produced in the euphotic zone (Stein, 1991; Demaison and Moore, 1980). Proximity to land can result in conditions well-suited for the deposition of organic matter, because the rapid deposition of terrestrial organics allows the organics to be buried and preserved with minimal environmental decomposition (Stein, 1991). Nearshore locations would therefore be the best locations to find areas high in organics (Stein, 1991); however, there are other studies that show contrasting data (Zagorski et al., 2012). Research by Zagorski et al. has shown that higher concentrations of organic matter can accumulate in areas with lower deposition rates, and that in some cases high amounts of deposition can dilute the organic carbon in the sediment (Zagorski et al., 2012; Smith and Leone, 2010). Further diagenesis can impact the amount of organic carbon preserved and change the resulting geochemical signal in the rock record. Although in most cases an increase in sediment deposition and burial causes increased organic carbon burial, in some cases rapid sediment accumulation can result in diluted organic matter concentrations and can decrease organic carbon content in sediments (Galy et al., 2007; Ibach, 1982;).

\subsection{Overview of Geochemical Proxies}

\subsubsection{Trace Element Analysis}

Trace element analysis of shales (such as $\mathrm{Mo}, \mathrm{V}, \mathrm{Ni}$, and $\mathrm{Cr}$ ) were used to identify periods of anoxia or euxinia, in addition to assessing depositional environments and sediment sources in several studies (see table 2) (e.g. Locklair et al., 2011; Tribovillard et al., 2006; Algeo and Maynard, 2004). Increases in trace metals such as Mo, V, Ni, and Cr can occur in sediments due to chemical sorption, settling, or biological processes (Dean et al., 1984). Cr, Mo and Ni are common in black shales with anoxic sediments. Mo, U, V, and Ni become enriched in anoxic sediments, due to low solubility of these elements under low oxygen conditions (Meyer and 
Kump, 2008; Algeo and Maynard, 2004). These trace metal ratios normalized to aluminum are used to identify areas with increased organic matter influx (Dean et al., 1984). When normalized to aluminum, trace metals $\mathrm{Mo} / \mathrm{Al}$ and $\mathrm{V} / \mathrm{Al}$ plots serve as proxies for anoxia that are not influenced by changes in sedimentary input (Locklair, et al., 2011).

\begin{tabular}{|l|l|l|}
\hline Trace Element Signature & Interpretation & Sources \\
\hline $\mathrm{Ca} / \mathrm{Al}, \mathrm{Mg} / \mathrm{Al}$, and & $\begin{array}{l}\text { Proxies for carbonate content in } \\
\text { sediment. High levels indicate } \\
\text { greater amounts of carbonate } \\
\text { deposition }\end{array}$ & $\begin{array}{l}\text { (Chen et al., 2015; Murphy et } \\
\text { al., 2000; Rimmer et al., } \\
\text { 2004; Schmitz, 1987; } \\
\text { Shimmield, 1992) }\end{array}$ \\
\hline Ti/Al ratio & $\begin{array}{l}\text { High levels indicate Ti-heavy silt } \\
\text { and sand and higher rates of } \\
\text { clastic input. }\end{array}$ & $\begin{array}{l}\text { (Murphy et al., 2000; Rimmer } \\
\text { et al., 2004; Schmitz, 1987; } \\
\text { Shimmield, 1992) }\end{array}$ \\
\hline $\begin{array}{l}\text { Trace metal ratios } \\
\text { V/(V+Ni), V/Cr, Ni/Co, } \\
\text { U/Th, and Mo/Al }\end{array}$ & Proxies for anoxia. & $\begin{array}{l}\text { (Calvert et al., 1996; Hatch } \\
\text { and Leventhal, 1992; } \\
\text { Locklair et al., 2011; Mangini } \\
\text { et al., 2001; Rimmer et al., } \\
\text { 2004) }\end{array}$ \\
\hline
\end{tabular}

Table 2: Common sediment record trace element proxies used to determine clastic input as well as redox conditions.

Uranium content is an important proxy for redox conditions because uranium from ocean water becomes much more readily adsorbed to sediments in anoxic environments but is not dependent on water column Fe-Mn redox cycling (Tribovillard et al., 2006; Mangini et al., 2001). Chromium (Cr) may adsorb readily to substrates under anoxic conditions so high amounts of $\mathrm{Cr}$ could indicate anoxic conditions; however, other research has found that $\mathrm{Cr}$ is detrital and not affected by anoxia, so this uncertainty must be taken into account when analyzing trace metal data (Tribovillard et al., 2006; Rimmer et al., 2004). Ni is released into the substrate when organic matter undergoes diagenesis or decay and precipitates again in the substrate under anoxic or reducing conditions (Tribovillard et al., 2006). Mo becomes more easily fixed to sediment in anoxic sulfidic environments (Chen et al., 2015; Algeo and Maynard 2004; Werne et al., 2002; 
Emerson and Huested, 1991). Increases in Mo concentration in sediment represent a decrease in aquatic oxygen content (Werne et al., 2002; Emerson and Huested, 1991). In oxic environments, molybdenum is in the VI form, whereas in reducing conditions Mo is in the IV form (Emerson and Huested, 1991). Mo-S minerals will precipitate when pyrite is present due to the lower amount of energy needed to precipitate pyrite (Emerson and Huested, 1991). Vanadium IV and V adsorption to sediments increases when in the reduced form (Emerson and Huested, 1991). V (IV) substitutes for $\mathrm{Mg}$ in the porphyrins, defined as the byproducts of chlorophyll in organicrich shales (Emerson and Huested, 1991).

Trace metal analysis has also been used by several researchers to interpret rates of clastic influx and the redox conditions at the time of deposition (See Table 2). Trace elemental ratios like $\mathrm{Ti} / \mathrm{Al}$ and $\mathrm{Si} / \mathrm{Al}$ can be used to identify rates of clastic input (Rimmer et al., 2004; Murphy et al., 2000; Schmitz, 1987). It is standard procedure to normalize trace elements to Ti, Al, or Si to minimize the detrital sedimentary input signal in the geochemistry (Werne et al., 2002). The $\mathrm{Ti} / \mathrm{Al}$ ratios were used in this study because titanium occurs mainly in coarser-grained sediments such as sand and silt and is not impacted by biogenic silica, whereas aluminum mainly occurs in clays (Rimmer et al., 2004). For the Treedam core, these elemental proxies were helpful in determining complex shifts in marine redox conditions and general geochemistry of the Pierre Shale.

\subsubsection{Clay Mineralogy}

X-ray diffraction mineralogy analysis was used to confirm the presence of volcanic ash layers containing montmorillonite (Christidis, 2008; Bernoulli et al., 2004). Identifying the presence of montmorillonite was important because it is commonly found in ash deposited in marine environments and altered by magnesium substitution (Bernoulli et al., 2004; Cadrin et al., 
1995). By confirming the presence of ash layers in the Treedam core, a degree of confidence was established that the plausible impact of volcanism on the chemostratigraphic record of the units overlying ash beds was being investigated.

\subsubsection{Carbon Isotope Composition}

Organic carbon stable isotope ratios were used to identify organic matter preserved in shale, organic matter alteration, and organic preservation conditions during the time of deposition (Calvert et al., 1996; Meyers and Ishiwatari, 1993; Arthur et al., 1985; Maynard, 1981). The same factors that affect rates of carbon burial and preservation, such as water depth, organic matter composition, and distance from continental margins, also directly impact the marine carbon isotope fractionation (Calvert et al, 1996; Hinga et al., 1994; Hayes, 1993; Maynard, 1981). Stable isotopes of organic carbon can indicate whether the sediment was deposited in marine or freshwater conditions. Fractionation of organic carbon isotopes during photosynthesis gives land and marine plants and algae unique carbon isotope ratios (Ramkumar, 2015; White, 2015; Meyers, 1992). Stable isotope ratios are different between C3 and C4 plants due to their differing photosynthetic pathways (Khim et al., 2008; Dean et al., 1986). C3 plants are terrestrial and aquatic plants that use the C3 Calvin pathway during photosynthesis (Ramkumar, 2015; White, 2015; Arbor, 1994). In most isotope records, terrestrial C3 plants discriminate against ${ }^{13} \mathrm{C}$ and select the lighter carbon isotope, leading to a depleted $\delta^{13} \mathrm{C}$ range of -24 to -32\%o (Ramkumar, 2015; White, 2015; Wang et al., 2013; Waseda et al., 1995; Hayes, 1993; Meyers, 1992; Farquhar et al., 1989). If the locality has a high terrestrial input, the sediments will have a stronger C3 plant isotopic signal (White, 2015; Sharp, 2007; Calvert et al., 1996; Meyers, 1992). C4 plants are plants that use the C4 Hatch Slack pathway for photosynthesis, allowing more ${ }^{13} \mathrm{C}$ to be used for photosynthesis, resulting in $\delta^{13} \mathrm{C}$ values around 
-7\% (Arbor, 1994). C4 plants had not yet evolved during the Late Campanian so C4 plant isotope ranges were not considered for this study.

Carbon isotope signatures in algae differ between marine and terrestrial aquatic environments due to the differences in inorganic carbon sources used in photosynthesis (White, 2015; Sharp, 2007; Hinga et al., 1994; Meyers, 1992; Sackett et al., 1965). Atmospheric $\mathrm{CO}_{2}$ is the major source of carbon for freshwater terrestrial environments, whereas in marine environments carbon is found as $\mathrm{HCO}_{3}-$ (White, 2015; Sharp, 2007; Meyers, 1992). In marine environments, the carbon source $\mathrm{HCO}_{3}$ - is already enriched at $0 \%$ (Khim et al., 2008; Sharp, 2007; Waseda et al., 1995; Meyers, 1992); therefore, a greater uptake of heavy ${ }^{13} \mathrm{C}$ occurs during photosynthesis in marine environmentss, resulting in $\delta^{13} \mathrm{C}$ values in the range of -22 to $-18 \%$ in marine sediments (Khim et al., 2008; Sharp, 2007; Waseda et al., 1995; Meyers, 1992). Isotopically enriched signatures in marine sediment are good indicators of the marine origin of algal matter, whereas depleted $\delta^{13} \mathrm{C}$ isotopic signatures indicate organic matter input from terrestrial environments. Hence, enrichment in $\delta^{13} \mathrm{C}$ has been correlated with transgression, or a rising sea level, while $\delta^{13} \mathrm{C}$ depletion has been attributed to shoreline regression. (Zakharov et al., 2013; Jarvis et al., 2006).

Burial rates of organic carbon were elevated throughout the history of the Cretaceous Western Interior Seaway, and these elevated burial rates are reflected in the positive $\delta^{13}$ Corg isotope excursions in Cretaceous sediment. (Arthur et al., 1985; Locklair et al., 2011). In spite of elevated organic carbon burial rates during the Cretaceous Period, the $\delta^{13} \mathrm{C}$ signatures of the Cretaceous Western Interior Seaway are still 5-7\%o lighter than present-day values due to increased burial rates, higher availability of light atmospheric $\mathrm{CO}_{2}$, and increased productivity (Meyers, 1992; Dean, Arthur, and Claypool, 1986; Arthur et al., 1985). Late Cretaceous carbon 
isotopes for this time period were also found to mirror sea level changes (Zakharov et al., 2013; Jarvis et al., 2006).

Research on carbon isotope fractionation has shown that blue green algae and photosynthetic bacteria have the lightest $\delta^{13} \mathrm{C}$ values in $\mathrm{CO}_{2}$ saturated waters, such as in hot springs (Dean et al., 1986). Therefore light $\delta^{13} \mathrm{C}$ values could indicate the presence of bluegreen alagae or photosynthetic bacteria in the Late Campanian Western Interior Seaway.

Carbonate ( $\delta^{13} \mathrm{C}$ carb) isotope signature, on the other hand, shows changes that pertain to the dissolved inorganic carbon. Carbonate formation fixes and fractionates dissolved inorganic carbon and takes it out of solution, enriching inorganic carbon by 1-2\%o (Locklair et al., 2011). Enrichments in $\delta^{13} \mathrm{C}$ carb can indicate light carbon taken out of solution caused by rapid burial of ${ }^{12} \mathrm{C}$ rich organic matter or an increase in photosynthesis by marine organisms (Chen et al., 2015; Spofforth et al., 2010; Louis-Schmid et al., 2007). Enriched carbonate isotopes can also occur when high amounts of organic carbon are buried and lead to a light carbon sink from the water column into the sediment, leading to a lack of ${ }^{12} \mathrm{C}$ in the water column (Louis-Schmid et al., 2007). An increase in photosynthesis is shown by a positive shift in $\delta^{13}$ Carb due to consumption of light carbon (Chen and Sharma, 2016). Positive excursions in $\delta^{13} \mathrm{C}$ can, therefore, be used as a proxy for high amounts of organic carbon burial in sediments and elevated photosynthesis levels (Louis-Schmid et al., 2007).

In anoxic environments $\delta^{13} \mathrm{C}$ carb depletions below $0 \%$ occurred due to the release of enriched $\mathrm{CO}_{2}$ from altered organic matter (Chen et al., 2015). Shift in $\delta^{13} \mathrm{C}_{\text {carb }}$ towards depleted values could also indicate lower biological activity (Chen et al., 2015; Meyers, 1992). Oxidation and precipitation of organic matter releases light carbon back into the marine carbon pool, 
resulting in a negative shift in $\delta^{13} \mathrm{C}$ carb (Chen and Sharma, 2016; Freeman, 2001). Depletions in

${ }^{13} \mathrm{C}$ are related to increases in organic nutrient content, because nutrients are released with organic matter formation and oxidation in deeper waters (Freeman, 2001). Ground water, surficial runoff from terrestrial environments, and thermal maturation of hydrocarbons can also result in shifts towards more depleted $\delta^{13}$ Ccarb (Chen and Sharma, 2016; Freeman, 2001).

\subsubsection{Nitrogen Isotope Composition}

Nitrogen isotope signatures are used to differentiate between terrestrial and marine organic matter sources and redox conditions (Ramkumar, 2015; Calvert et al., 1996; Altabet and Francois, 1994; Meyers and Ishiwatari, 1993; Rau et al., 1989; Peterson et al., 1985). Marine organic matter tends to be more enriched in ${ }^{15} \mathrm{~N}$ compared to terrestrial organic matter because nitrogen-fixing phytoplankton consume and fractionate dissolved nitrate in marine waters and gradually cause the remaining nitrogen in the water column to become more enriched in ${ }^{15} \mathrm{~N}$ (Ramkumar, 2015; Calvert et al., 1996; Altabet and Francois, 1994; Meyers and Ishiwatari, 1993; Rau et al., 1989; Peterson et al., 1985). Therefore marine organic matter has higher ${ }^{15} \mathrm{~N}$ content compared to terrestrial organic matter. Consumption of dissolved nitrate in marine waters via both aerobic and anaerobic processes results in enrichment of residual nitrate (a $\delta^{15} \mathrm{~N}$ range of +7 to upwards of $+10 \%$ ), whereas fixed atmospheric molecular nitrogen in marine waters has a $\delta^{15} \mathrm{~N}$ ratio of around $0 \%$, matching the signature of the nitrogen fixers that consume it (Jenkyns et al., 2001; Meyers and Ishiwatari, 1993).

Ocean productivity is limited by the amount of nitrogen present in the system, causing $\delta^{15} \mathrm{~N}$ isotope fractionation to be dependent on all aspects of the marine nitrogen cycle, such as denitrification, nitrogen fixation, and nitrification (Ramkumar, 2015; Sharp, 2007; Velinsky et al., 1991). The two major factors impacting marine nitrogen isotope fractionation are 
denitrification and nitrogen fixation (Quan et al., 2008; Khim et al., 2007; Minoura et al., 1997; Calvert et al., 1996). Denitrification occurs when nitrate is reduced to other gaseous nitrogen species via anaerobic processes (Ramkumar, 2015; White, 2015; Cline and Kaplan, 1975). Oxygen deficiency has been shown to promote denitrification in the water column, and so positive excursions in $\delta^{15} \mathrm{~N}$ caused by denitrification are used to indicate oxygen poor bottom water conditions (Quan et al., 2013; Minoura et al., 1997). Denitrification can be identified by more positive $\delta^{15} \mathrm{~N}$ nitrogen isotope excursions caused by anaerobic bacterial consumption of light reduced ${ }^{14} \mathrm{~N}$ (Ramkumar, 2015; Lyons et al., 2009; Khim et al., 2008; Quan et al., 2008; Li and Bebout, 2005; Calvert et al., 1996; Altabet and Francois, 1994). Positive shifts in $\delta^{15} \mathrm{~N}$ can also be attributed to diagenetic alteration due to the release of ${ }^{14} \mathrm{~N}$ from the sediment via hydrolysis of organic matter (Khim et al., 2008; Altabet and Francois, 1994).

Nitrogen can be added to marine environments in several ways. The first is through nitrogen uptake by phytoplankton during plankton blooms at the surface (Sigman et al., 2009). The plankton consumes previously fixed nitrogen during the bloom, but then releases nitrogen back into the water column as particulate nitrogen, causing the nitrogen isotope pools to be neither lost nor replenished (Sigman et al., 2009). The mechanism for which plankton consume fixed nitrogen is called Rayleigh fractionation (Sigman et al., 2009). Another way nitrogen can be fixed is through a steady state model in which nitrogen is supplied and consumed simultaneously; however, the consumption is only partial, leading to a higher rate of fractionation and $\delta^{15} \mathrm{~N}$ enrichment (+7 to 10\%o) (Sigman et al., 2009). While there is still nitrogen being added, there is partial denitrification in the steady state model (Sigman et al., 2009). 
The major source of marine nitrogen is nitrogen fixation. Nitrogen fixation accounts for most of the new nitrogen added to marine nitrogen pools. and is caused by nitrogen-fixing primary producers such as cyanobactera and trichodesmium (Zhang et al., 2014; Sigman et al., 2009). Nitrogen fixation is the process of turning dissolved atmospheric nitrogen gas into available nitrogen in the water column as biomass (Sigman et al., 2009). Remineralization of this added nitrogen introduces new nitrogen into marine fixed nitrogen pools (Sigman et al., 2009). Normal $\delta^{15} \mathrm{~N}$ values associated with nitrogen fixation range from -2 to $+1 \%$ (Zhang et al., 2014; Sigman et al., 2009). There are special cases in which marine nitrogen signals can become depleted in ${ }^{15} \mathrm{~N}$, even though they are adding fixed nitrogen to the nitrogen pool. Most nitrogen fixing organisms are referred to as diazotrophs, which use molybdenum nitrogenase enzymes to fix atmospheric nitrogen into other nitrogen species (Zhang et al., 2014). In some cases diazotrophs must use alternative vanadium or iron nitrogenase enzymes to fix $\mathrm{N}_{2}$ (Zhang et al., 2014). These $\mathrm{N}_{2}$ fixation mechanisms can result in depleted $\delta^{15} \mathrm{~N}$ values from 0 to $-6 \%$ (Zhang et al., 2014).

Shifts towards depleted $\delta^{15} \mathrm{~N}$ values in modern oceans also occur when nutrients are supplied faster to the photic zone than they can be consumed by plankton, resulting in increased primary production and lighter $\delta^{15} \mathrm{~N}$ values in the settling organic matter (Calvert et al., 1996). These negative $\delta^{15} \mathrm{~N}$ fluctuations could represent an influx of new nitrate-rich water or an abundance of ${ }^{14} \mathrm{~N}$ due to lower consumption by primary producers (Khim et al., 2007). This enhanced primary production combined with increases of respiration below the euphotic zone can result in water column anoxia (Calvert et al., 1996). Values can also be negative due to selective preservation, higher production of $\delta^{15} \mathrm{~N}$ depleted biomass, or due to release of enriched 
${ }^{15} \mathrm{~N}$ in the form of ammonia from the sediment (Khim et al., 2008; Zerkle et al., 2008; Khim et al., 2007; Lehmann et al., 2002; Freudenthal et al., 2001).

\subsubsection{Carbon/Nitrogen Ratios}

Terrestrial and aquatic organic matter can also be distinguished based on the $\mathrm{C} / \mathrm{N}$ elemental composition ratios (Sharp, 2007; Meyers, 1994; Meyers and Ishiwatari, 1993). General increases in $\mathrm{C} / \mathrm{N}$ ratios indicate a shift from algal plant to land plant organic matter contributions (Sharp, 2007; Meyers and Ishiwatari, 1993). Different C/N ratios also distinguish terrestrial C3 plants, marine algae, and lacustrine algae (Sharp, 2007; Meyers, 1994). The cellulose content of organic matter in marine settings can affect the $\mathrm{C} / \mathrm{N}$ ratios deposited in the marine sediment (Sharp, 2007; Meyers, 1994; Meyers and Ishiwatari, 1993). Nonvascular aquatic plants that lack cellulose contain proteins with low $\mathrm{C} / \mathrm{N}$ ratios (4-10), whereas vascular plants containing cellulose contain C/N ratios greater than 20 (Meyers, 1994; Meyers and Ishiwatari, 1993).

\section{CHAPTER 3: METHODS}

\subsection{Sample Collection}

For this study, the Treedam core was stored and transported in 5-foot sections. Only every other 5-foot core section was available for sampling, with the exception of the core segment containing the Crow Creek Member. With the help of the South Dakota Geological Survey, a total of 89 samples were selected from the Treedam core based on gamma ray peaks, volcanic ash depths, and the Crow Creek depth in each 5-foot segment of core. The volcanic ash layers were chosen visually and verified by X-ray mineralogy (Totten et al., 2005; Shen et al., 2013). Samples were taken from the core immediately above, within, and below each volcanic ash layer to accurately determine correlations between volcanic ash deposition and changing redox conditions (See figures 5 through 11). 


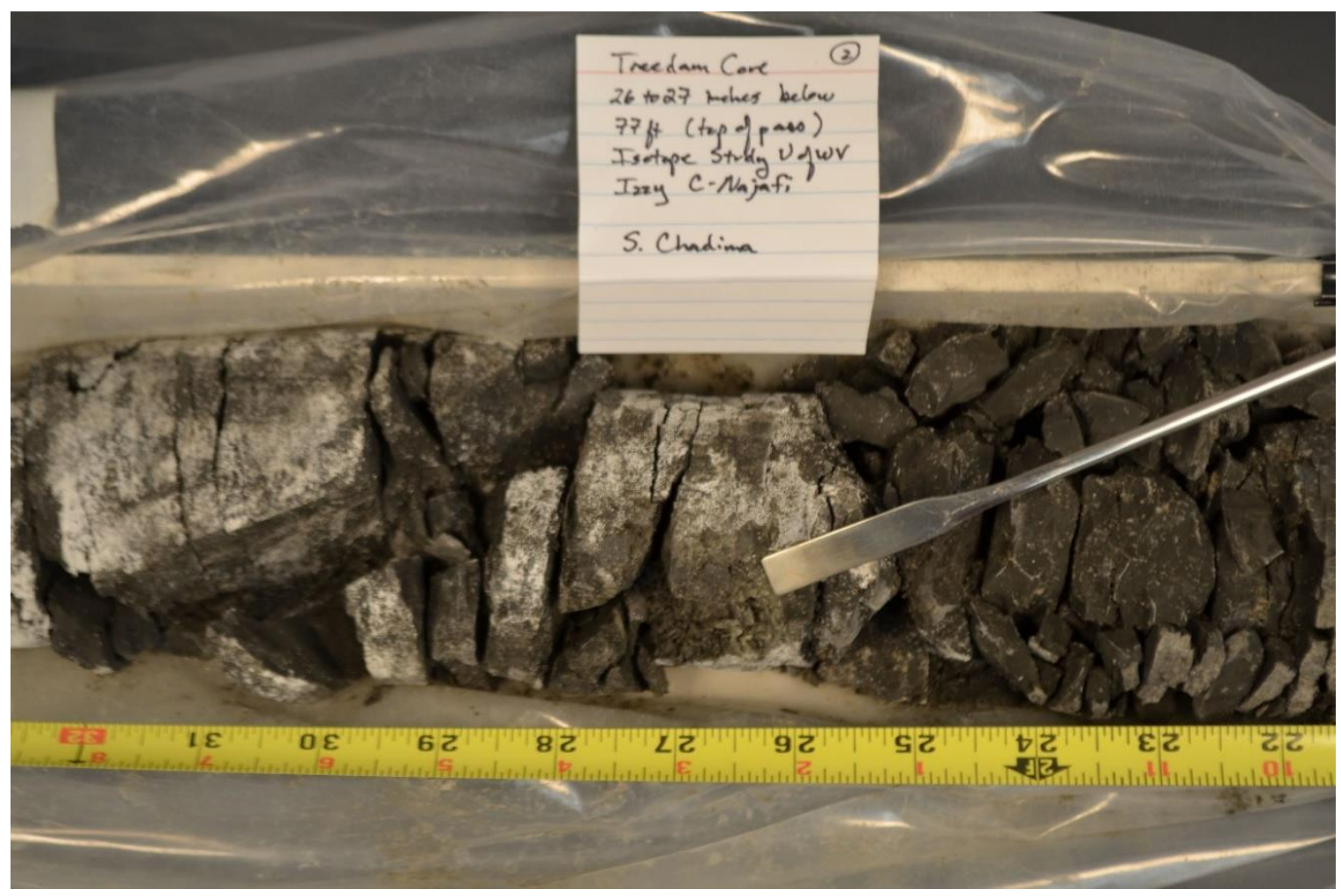

Figure 5: Treedam core depth sampled for volcanic ash B1 at 77.2 feet (23.53 meters).

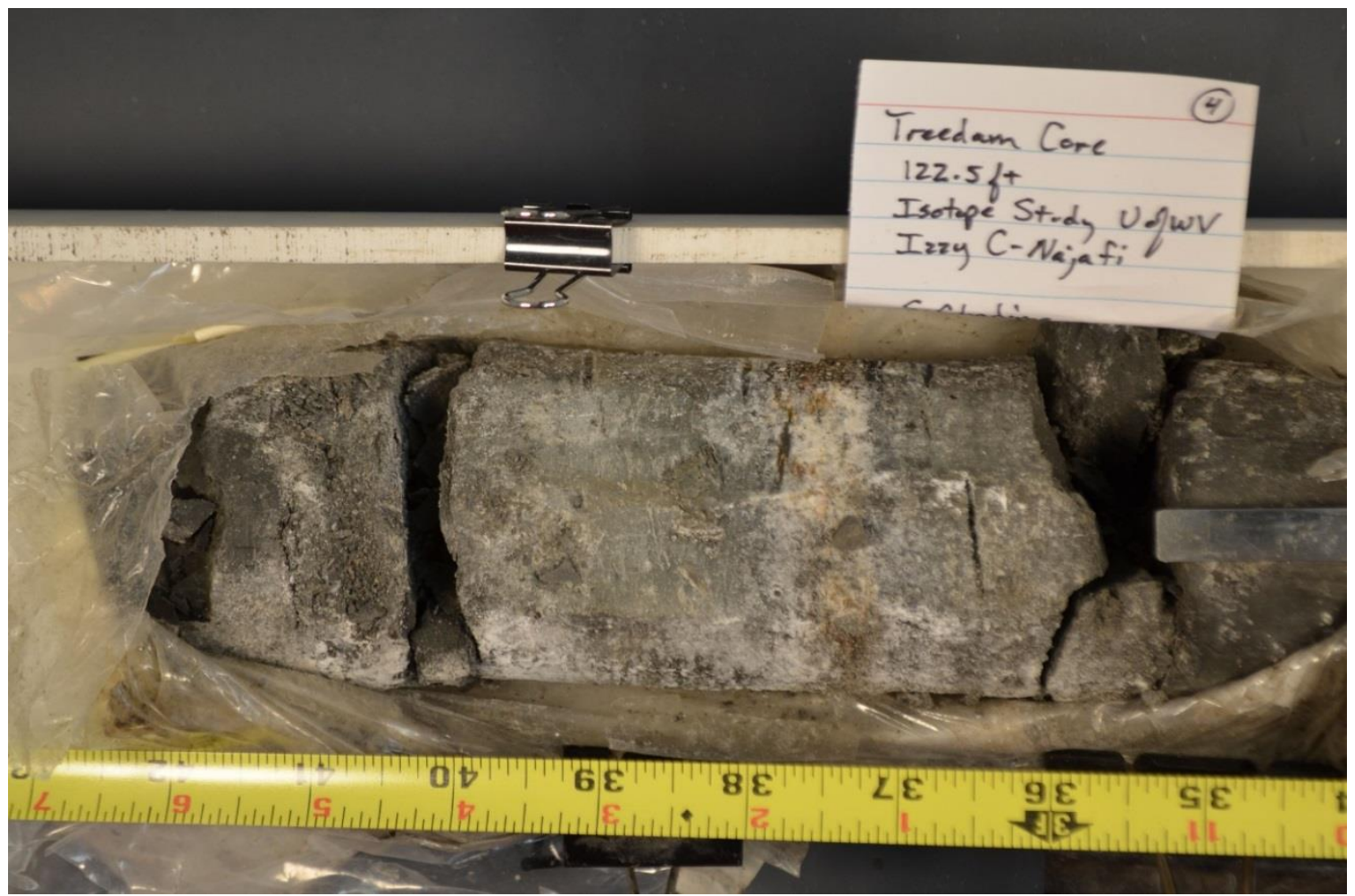

Figure 6: Treedam core depth sampled for volcanic ash B2 at 122.5 feet (37.33 meters). 


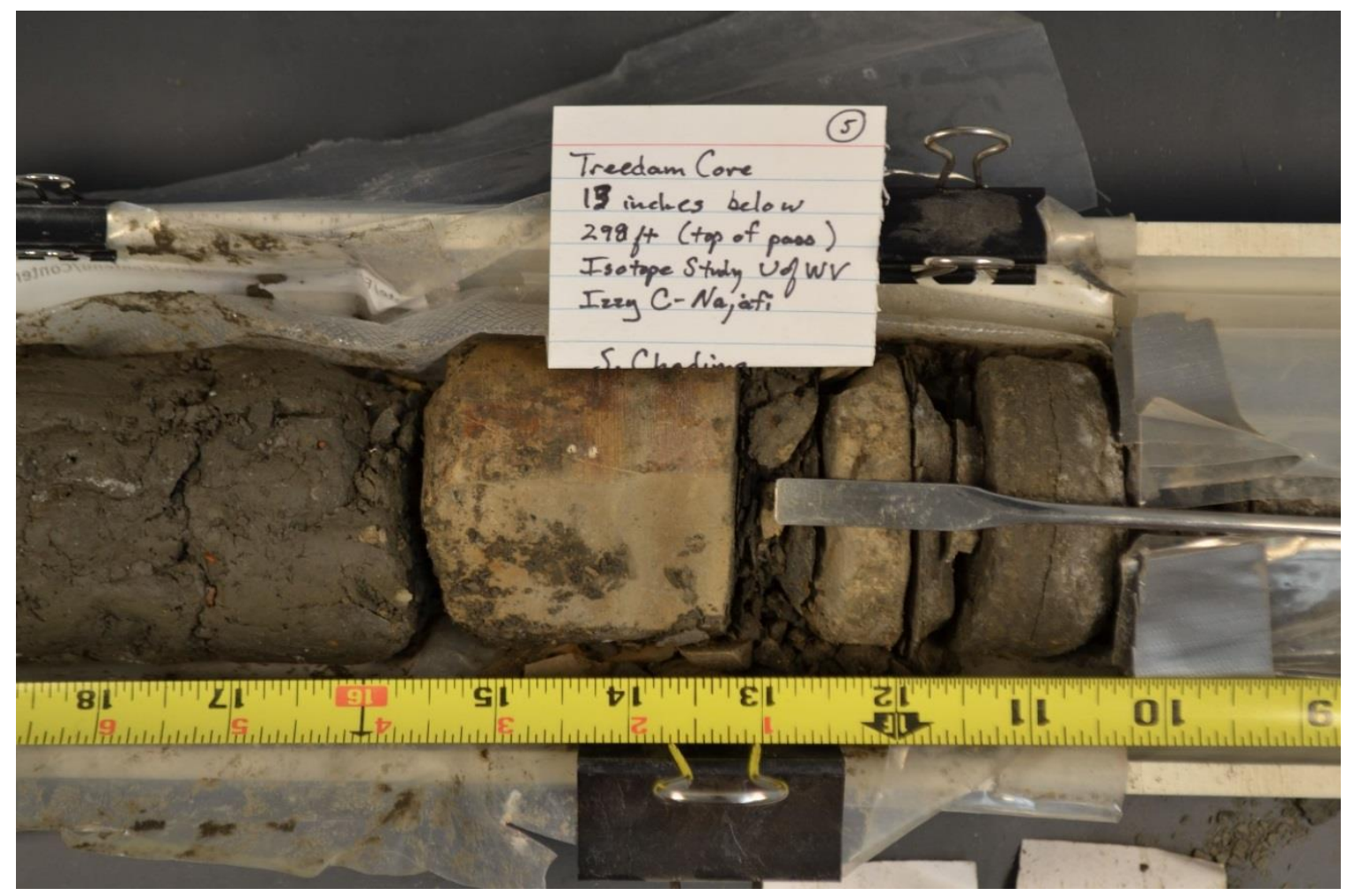

Figure 7: Treedam core depth sampled for volcanic ash B3 at 299.08 feet (91.15 meters).

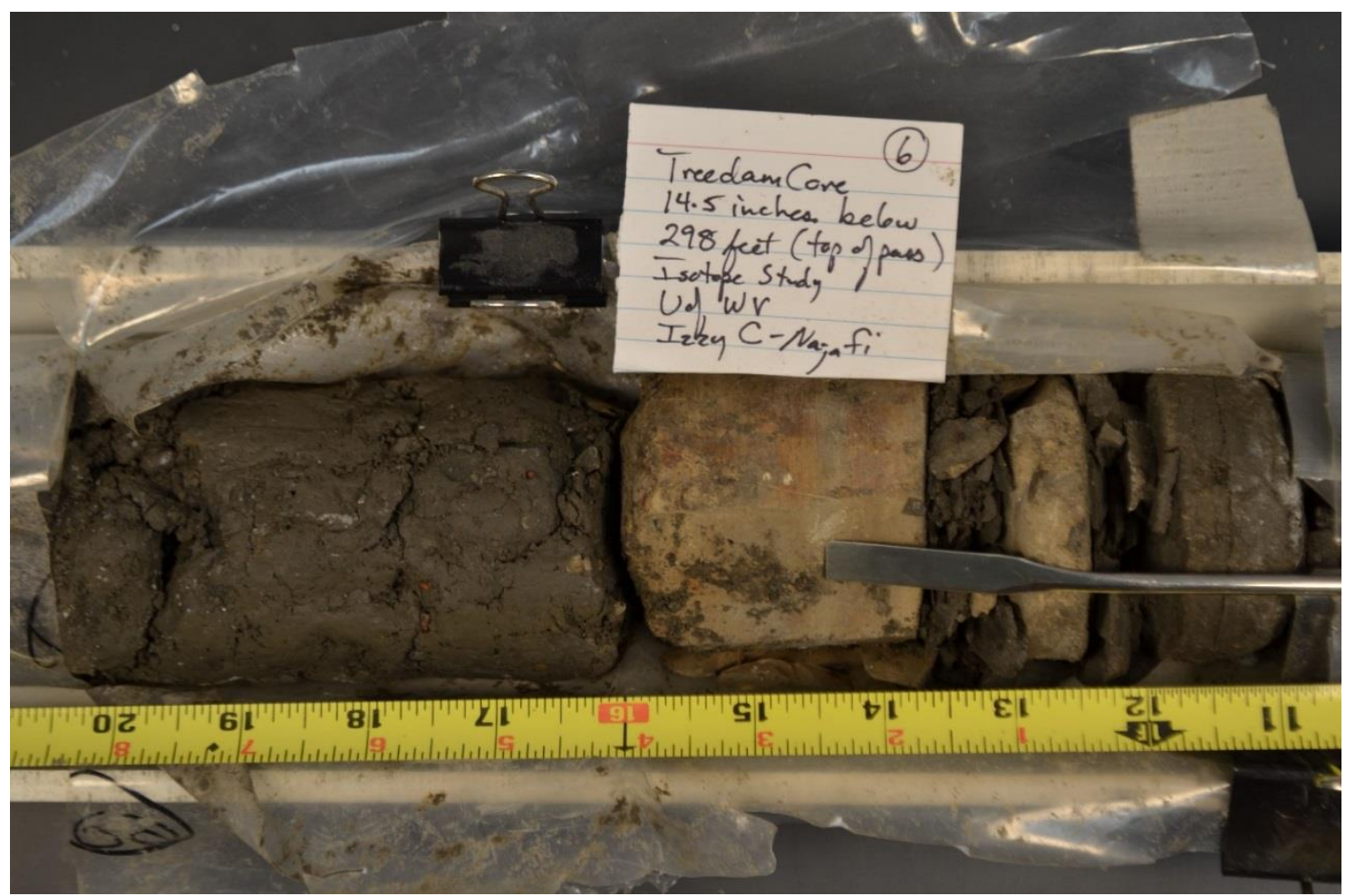

Figure 8: Treedam core depth sampled for volcanic ash B4 at 299.21 feet (199.19 meters). 


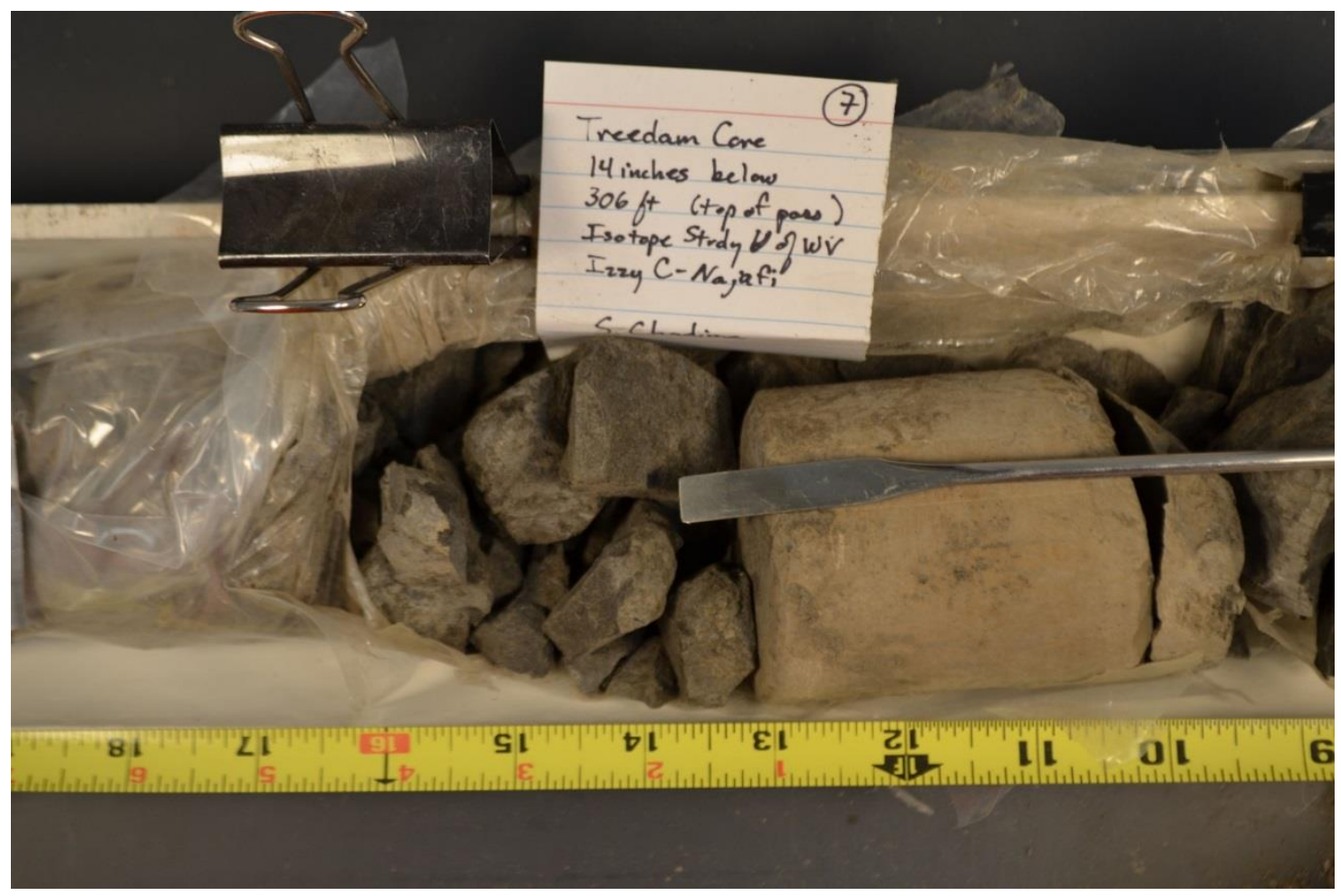

Figure 9: Treedam core depth sampled for volcanic ash B5 at 307.1 feet (93.60 meters).

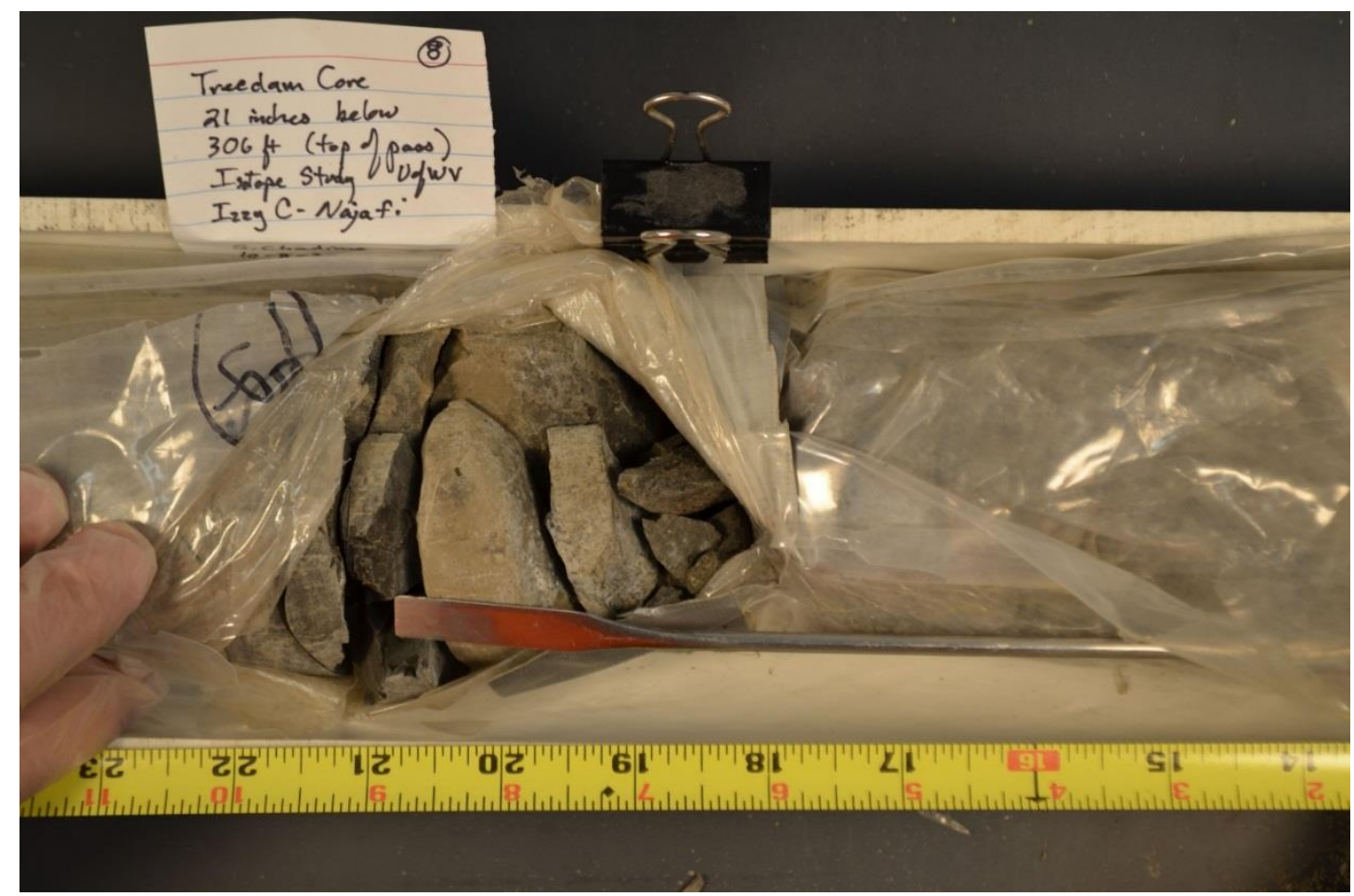

Figure 10: Treedam core depth sampled for volcanic ash B6 at 307.75 feet (93.80 meters). 


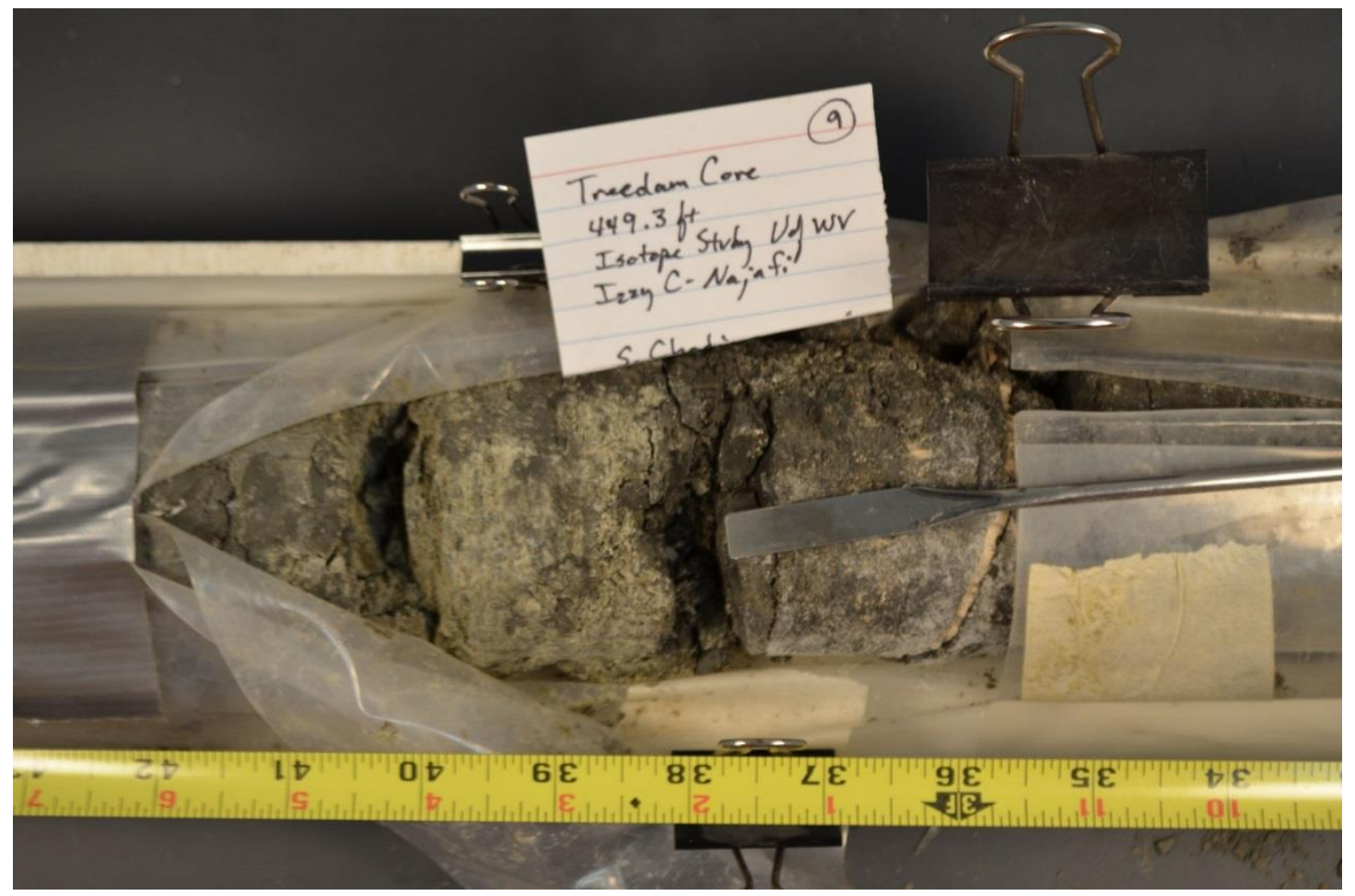

Figure 11: Treedam core depth sampled for volcanic ash B7 at 499.3 feet (152.18 meters).

Samples from the Crow Creek Member were requested from RESPEC and the South Dakota School of Mines. The Crow Creek Member was collected as unconsolidated sand in plastic bags, each of which represented 1 cumulative foot of core. One sample was collected from each of the four Crow Creek bags of sand for a total of four samples. The data collected for these four samples was likely affected by mixed signatures within the core, which was taken into account during the analysis.

When preparing all samples for stable isotope, trace element, and source rock analysis, the outer rind of the core samples was scraped off to avoid contamination from drilling fluids. Nitrile gloves were used at all times to avoid contaminating the sample. Samples were stored and dried in pre-cleaned glass beakers and heated to $45^{\circ} \mathrm{C}$. The samples were then ground to $<75 \mu \mathrm{m}$ in a rock grinder (Murphy et al., 2000). Sample preparations for source rock analysis, trace element analysis, and stable isotope analysis are described below. 


\subsection{X-Ray Diffraction}

Seven volcanic ash beds (see Table 3 for depths) were analyzed using X-ray diffraction (XRD) mineralogy to confirm the presence of swelling clays and classify them as volcanic ash. There were nine samples collected total. Three samples from volcanic ash bed 1 (B1) were collected due to the acidic nature of the samples which were thought to have been impacted by their mineralogy. The samples from B1 were yellowish in color and had dissolved away parts of the aluminum foil it was wrapped in, unlike the rest of the volcanic ash samples.

XRD samples were analyzed by Proto Manufacturing using a PROTO XRD benchtop powder diffractometer. The samples were ground in an agate mortar and pestle with methanol and the slurry was mounted onto a low-background fused quartz plate. Samples were measured volcanic ashwith copper radiation at $30 \mathrm{kV}$ and $20 \mathrm{~mA}$. Due to instrument availability, not all samples were analyzed identically. Samples 1-6, and 9 used 2-65 degrees $2 \theta, 0.02$ degree step, 3 sec/step, with an energy-discriminating point detector. Samples 7 and 8 used 3-65 degrees $2 \theta$, 0.02 degree step, $3 \mathrm{sec} / \mathrm{step}$, and a Si drift detector.

Treedam Volcanic Ash Samples

\begin{tabular}{|c|c|c|}
\hline Depths $(\mathrm{ft})$ & XRD Sample Number & Ash Bed ID \\
\hline 79.08 & Treedam_1 & B1 \\
\hline 79.16 & Treedam_2 & B1 \\
\hline 79.41 & Treedam_3 & B1 \\
\hline 122.5 & Treedam_4 & B2 \\
\hline 299.08 & Treedam_5 & B4 \\
\hline 299.21 & Treedam_6 & B5 \\
\hline 307.17 & Treedam_7 & B6 \\
\hline 307.75 & Treedam_8 & B7 \\
\hline 449.3 & Treedam_9 & \\
\hline
\end{tabular}

Table 3: Depths of each sample analyzed for the Treedam core. Treedam_1, Treedam_2, and Treedam_3 were multiple samples from B1 taken because B1 showed unusual geochemical characteristics, such as $0 \%$ TOC and acidic properties when in contact with aluminum foil. 
Due to the mounting method, a sample displacement correction was required to get accurate peak positions of the 060 and $00 \ell$ for clay type determination. Jade powder XRD analysis software was used to determine sample displacement using the quartz phase alone. This sample displacement was then used to correct peak positions of clay phases. This was done using Equation 1.

\section{Equation 1:}

\section{$\Delta 2 \theta=-2 s * \cos \theta / R$}

Specimen displacement (s) was determined to be $+0.207 \mathrm{~mm}$. The value for $\mathrm{R}$ (diffractometer radius) is $143 \mathrm{~mm}$. The $\theta$ values were taken from each peak and corrected.

The XRD patterns are displayed in figure 12. For montmorillonite identification, the $2 \theta_{060}$

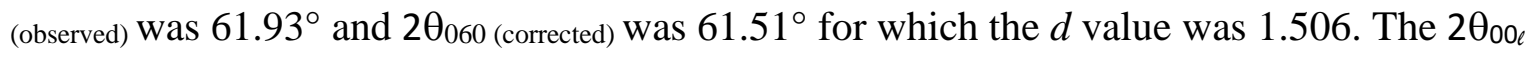

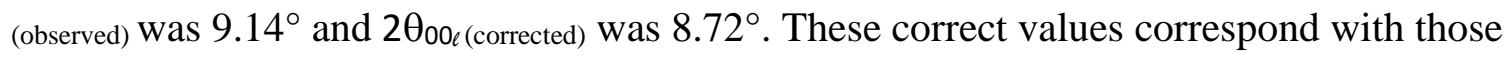
published in Moore and Reynolds's X-Ray Diffraction and the Identification of Clay Minerals (1989). The peak at $2 \theta \approx 26^{\circ}$ is the highest-intensity peak of the quartz phase. 


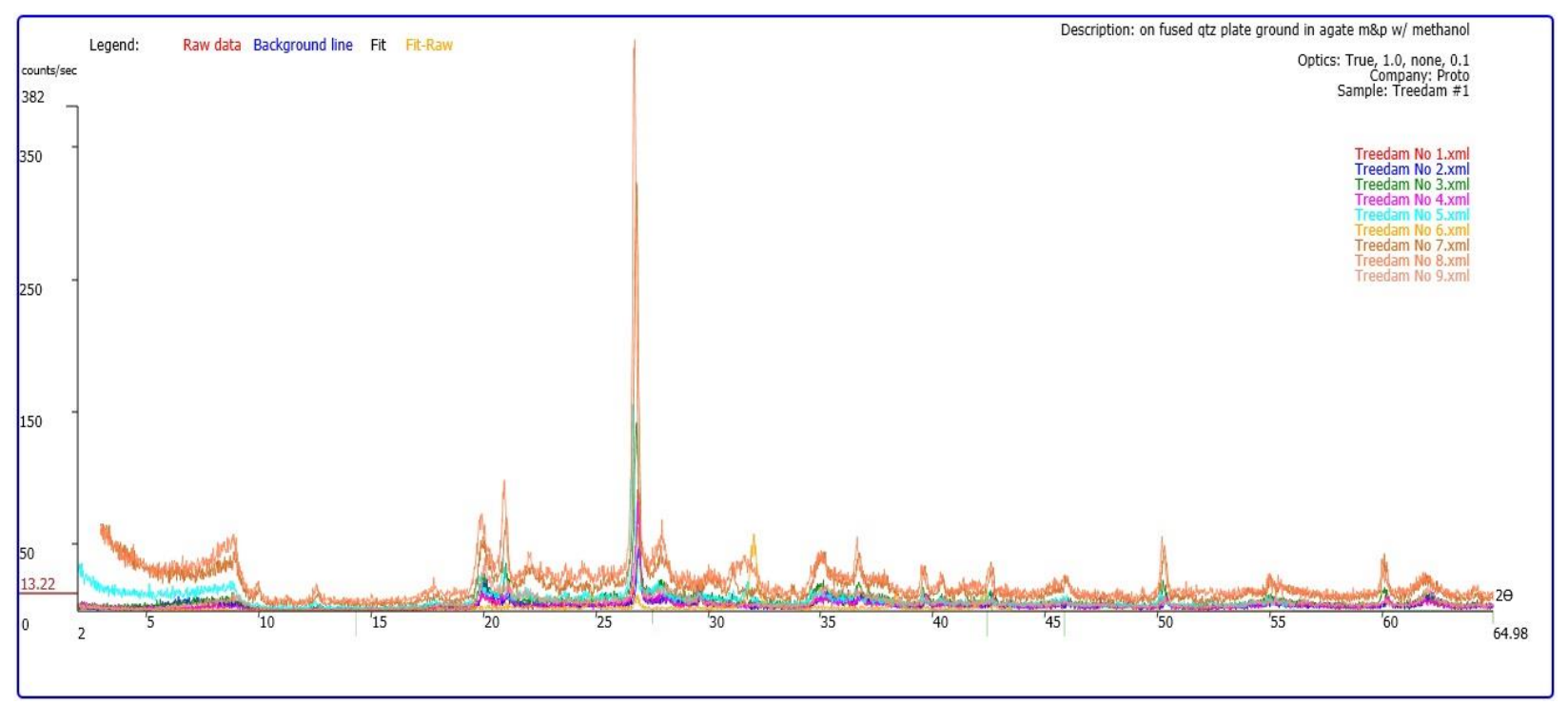

Figure 12: Overlapping X-ray diffraction patterns for each Treedam ash sample. Sample number corresponds to the volcanic ash number assigned in table 3.

\subsection{Organic Carbon and Nitrogen Stable Isotope Analysis}

Carbon and nitrogen isotope analysis was performed by the Stable Isotope Laboratory at West Virginia University. Samples were ground and sieved (about two grams of core per sample). For $\delta^{13}$ Corg and $\delta^{15} \mathrm{~N}$ analyses samples were de-carbonated with 1 molar hydrochloric

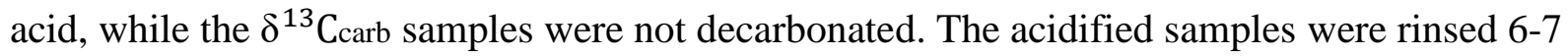
times with deionized water followed by centrifugation and were dried at $50{ }^{\circ} \mathrm{C}$. Carbon isotopic composition of carbonate $\left(\delta^{13} \mathrm{C}\right.$ carb) was measured using a Gas-Bench device online with a Delta Advantage gas isotope ratio mass spectrometer (IRMS). Stable carbon and nitrogen isotope analysis was conducted on a Costech ECS 4010 combustion elemental analyzer (EA), coupled to a Delta advantage isotope ratio mass spectrometer via a ConFlo IV interface. Measurement precision was determined by replicate analysis of samples and internal lab standards and was better than $+/-0.1 \%$ for $\delta^{13} \mathrm{C}$ and $+/-0.2 \%$ for $\delta^{15} \mathrm{~N}$. The $\delta^{13} \mathrm{C}$ and $\delta^{15} \mathrm{~N}$ values of the internal laboratory normalization and check standards were calibrated against their respective IAEA standards (i.e., NBS 18, NBS 19 and LSVEC for the $\delta^{13} \mathrm{C}$ of carbonates; USGS 40 and USGS 41 
for the $\delta^{13} \mathrm{C}$ and $\delta^{15} \mathrm{~N}$ of organics) and the values are reported in per mil (\%) relative to V-PDB and AIR, respectively. Organic carbon and nitrogen concentrations were also measured using a Costech ECS 4010 combustion EA with the decarbonated samples. The $\mathrm{C}$ and $\mathrm{N}$ contents were determined with a precision of $+/-0.5 \%$ for $\mathrm{C}$ and $+/-0.1 \%$ for $\mathrm{N}$.

\subsection{Total Organic Carbon (\% TOC)}

Source rock analysis was completed via Weatherford Laboratories Source Rock Analyzer, Total Petroleum Hydrocarbon- Total Organic Carbon (SRA TPH/TOC) located at the National Energy Technology Laboratory site in Morgantown, West Virginia. The standard used was the WFT Source Rock Standard 533 (P/N 810-141). Results for all of the Treedam core are shown in Figure 13.

\subsection{Inductively Coupled Plasma Mass Spectroscopy (ICP-MS)}

Trace element analysis was conducted using the ICP-MS at the National Energy Technology Laboratory in Pittsburgh, Pennsylvania. The ICP-MS is a Nexion 300d with universal cell technology made by Perkin Elmer with an accuracy of 1-2\%. Detection limits are in the parts per million (ppm) range for most minor and trace metals. Samples were prepared via lithium metaborate fusion followed by digestion in 5\% nitric acid. Data for sedimentation proxies and redox proxies are shown in figures 16 and 17 respectively. Standards included carbon-poor Bush Creek Shale from Pennsylvania (SBC-1) and oil-rich Green River Shale from Wyoming (SGR-1b). The internal standard used was $50 \mathrm{ppb}$ In.

\subsection{Statistical Analyses of Volcanic Ash Beds and Crow Creek Member}

Statistically significant changes in geochemical parameters were tested by using $\mathrm{Z}$ and $\mathrm{T}$ statistics. All core samples within one foot of all volcanic ash beds were chosen as the ash bed sample, and data was organized by distance from the ash bed. All core samples within one foot 
above and below the Crow Creek Member were chosen as the Crow Creek Sample. The null hypothesis tested was that the mean values for volcanic ash and Crow Creek core samples would not deviate from the overall mean of the Pierre Shale samples. This hypothesis implies that no change had taken place in the geochemical parameters of the Pierre Shale as a result of ash deposition or the Crow Creek Member depositon. The null hypothesis would be rejected for either sample set if $\mathrm{p}<0.01$, or the probability of obtaining the same data provided the null hypothesis is true is below $1 \%$. If the null hypothesis were to be rejected, then it would indicate that the depositional events for the volcanic ash beds and/or the Crow Creek Member did have a significant effect on marine geochemistry.

For the volcanic ash beds, Z-statistics were used for $\delta^{13} \mathrm{C}, \delta^{15} \mathrm{~N}, \% \mathrm{C}, \% \mathrm{~N}$, and $\mathrm{C} / \mathrm{N}$ ratios, while T-statistics were used for $\% \mathrm{TOC}$ and $\delta^{13} \mathrm{C}$ carb due to a smaller sample size. For the Crow Creek Member only T-statistics were used because $\mathrm{n}<30$ for all samples (Moore and McCabe, 2002). If the null hypothesis were to be rejected, then there would be evidence that ash deposition and/or the Crow Creek Member deposition had a significant impact on marine geochemical proxies. Both $\mathrm{T}$ and $\mathrm{Z}$ statistics were calculated using Equations 1 and 2. Standard deviation $(\sigma)$ for volcanic ash and Crow Creek subsample data sets are noted as $\sigma$. The calculation for standard deviation is shown in equation 2 (Moore and McCabe, 2002; Watkins, 2016). The letter $\mathrm{N}$ represents the number of values in the subsamples, $x i$ represents each sample value, $\mu$ represents the overall mean of the subsamples for each geochemical parameter (Moore and McCabe, 2002). 
Equation 2:

$$
\sigma=\sqrt{\frac{1}{N} \sum_{i=1}^{N}\left(x_{i}-\mu\right)^{2}}
$$

Symbol $x$ is the subsample mean, $\mu$ is the overall Treedam mean, and $\sigma$ is the standard deviation of the subsample as calculated in equation $2 . \mathrm{Z}$-scores and $\mathrm{t}$-scores were calculated using equation 3 (Moore and McCabe, 2002).

Equation 3:

$$
z=\frac{x-\mu}{\sigma}
$$

From the Z-scores and t-scores, p-values were calculated using GraphPad software (Motulsky, 2016). 


\section{CHAPTER 4: RESULTS}

\subsection{Stable Isotope and TOC Results}

Organic and carbonate $\delta^{13} \mathrm{C}, \delta^{15} \mathrm{~N}$, and TOC records of the Treedam core are shown in Figure 13. The results of the Treedam core $\delta^{13} \operatorname{Corg}$ analysis ranged from $-25.7 \%$ to $-27.2 \%$ with an average of $-26.6 \%$. Overall trends in the data show that there was only slight variation in $\delta^{13}$ Corg indicating that organic carbon sources did not vary widely during the deposition of the Pierre Shale. Carbonate $\delta^{13} \mathrm{C}$ values (figure 13) had a much wider range of values and spans from a maximum of $1.7 \%$ to a minimum of $-10.9 \%$. The majority of $\delta^{13}$ Carb values fell below 0\%o with an average of $-2.6 \%$. Below the Crow Creek Member, carbonate isotope values had the widest scatter of values. The Treedam $\delta^{15} \mathrm{~N}$ isotope ratios fluctuated between $-5.6 \%$ and $2.2 \%$ (Figure 13). The majority of nitrogen isotope data had an average of $-0.5 \%$ and plotted near atmospheric $\mathrm{N}_{2}$ levels (0\%o). There were two anomalous negative shifts that showed $\delta^{15} \mathrm{~N}$ values of $-5.6 \%$, and these were at depths of 499.28 feet (152.18 meters) in the Gregory Member and 378.95 feet (115.50 meters) in the DeGrey Member. Total organic carbon overall had a maximum of $1.8 \%$, a minimum of $0.01 \%$, and an average of $1.2 \%$. TOC overall decreased from the base of the core in the Gregory Member (512 feet/ 156.05 meters) to the Crow Creek Member (455 feet/ 138.68 meters) and then increased to $1 \%$ immediately above the Crow Creek Member and remained consistent at or above $1 \%$ TOC throughout the rest of the core. 

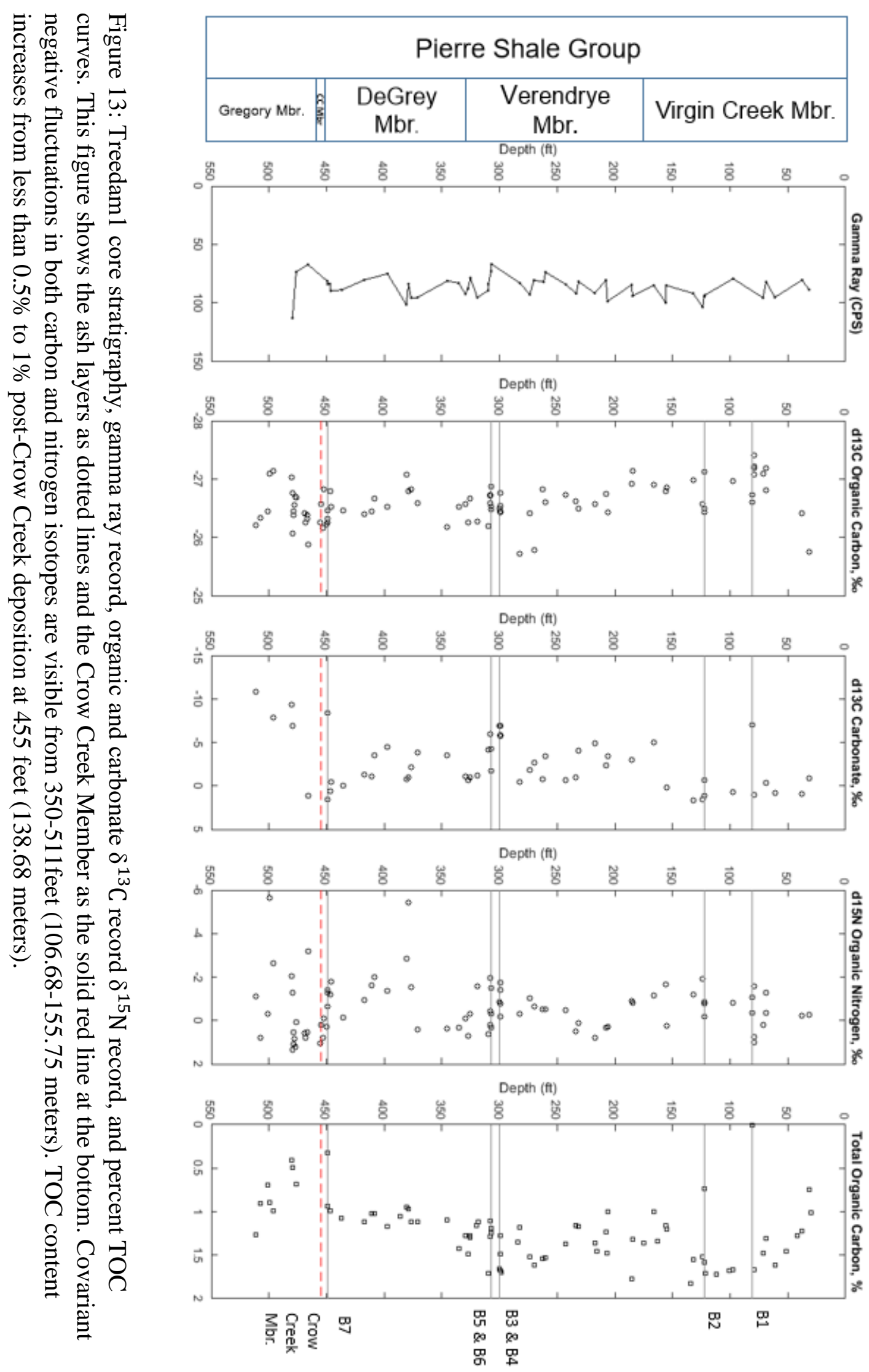


\subsection{C/N Ratios}

Carbon and nitrogen content of the Treedam core is shown in Figure 14 in the form of calculated weight percent. Concentrations of both organic carbon and organic nitrogen were low throughout the Treedam core (Figure 14). Weight percent content of carbon was below $2 \%$ and shows little variation throughout the core. Overall organic nitrogen content was also low for the Treedam core, with values ranging between 0 and 0.2 weight percent (Figure 14). Average carbon to nitrogen ratios were between 10 and 15 with a minimum of 3 and a maximum of 20 (Figure 14). Carbon/nitrogen weight percent ratios $(\mathrm{C} / \mathrm{N})$ decreased up-section throughout the core. 


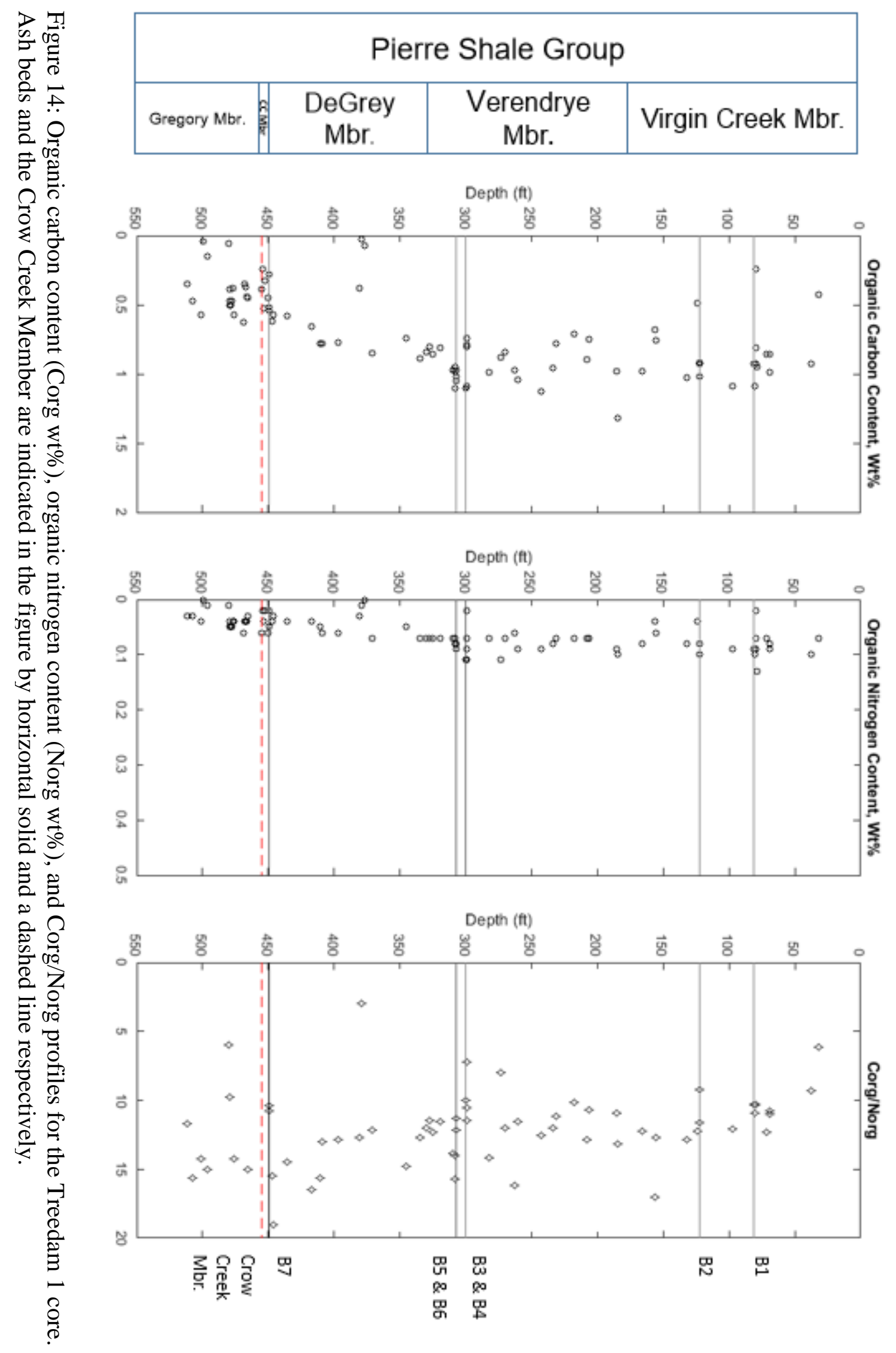




\subsection{Trace Element Data}

Figure 15 shows $\mathrm{Ti} / \mathrm{Al}, \mathrm{Ca} / \mathrm{Al}, \mathrm{Mg} / \mathrm{Al}$ and $\mathrm{Mn} / \mathrm{Al}$ ratios which were all used as proxies for clastic input and carbonate content. The $\mathrm{Ti} / \mathrm{Al}$ ratios were low with a maximum of 0.050 , a minimum of 0.015 , an average of 0.041 , and a standard deviation of 0.0069 . The majority of data plotted close to 0.05 and do not show major variations. The $\mathrm{Ca} / \mathrm{Al}$ ratios were also low with a maximum of 2.66, a minimum of 0.05 , an average of 0.21 , and a standard deviation of 0.29 . $\mathrm{Ca} / \mathrm{Al}$ values increased slightly around the Creek Member (455 feet/ 138.68 meters) and B7 (450 feet/ 137.16 meters). The maximum $\mathrm{Ca} / \mathrm{Al}$ value of 2.66 is at the top of the $\mathrm{B} 3$ volcanic ash bed (299.21 feet/91.20 meters). $\mathrm{Mg} / \mathrm{Al}$ ratios in the Treedam core had a maximum of $1.82, \mathrm{a}$ minimum of about 0.08 , an average of 0.17 , and a standard deviation of 0.18 . These values were also consistently low with little variation aside from the anomalously high value of 1.84 at B3 (299.21 feet/ 91.20 meters). The Mn/Al ratios were low with a maximum of 3.31, a minimum of 0.0014 , and an average of 0.076 , and a standard deviation of 0.36 . The maximum $\mathrm{Mn} / \mathrm{Al}$ value occurred at B3 (299.21 feet/ 91.20 meters) but there was little change aside from this anomalous value.

The temporal trend in redox proxies $\mathrm{V} /(\mathrm{V}+\mathrm{Ni}), \mathrm{V} / \mathrm{Cr}, \mathrm{U} / \mathrm{Th}$, and $\mathrm{Mo} / \mathrm{Al}$ for the Treedam core are shown in Figure 16. The V/(V+Ni) ratios showed little variation across the Treedam core. The maximum value was 0.89 , the minimum was 0.076 , the average was 0.76 , and the standard deviation was 0.14 . The highest amount of scatter was between 512 feet (156.06 meters) and 475 feet (144.78 meters) at the base of the Gregory Member with values spanning from 1 to 0 . Depleted values of $\mathrm{V} /(\mathrm{V}+\mathrm{Ni})$ were shown at each volcanic ash bed, and anomalously depleted values were also found at about 375 feet (114.3 meters) in the DeGrey Member. The $\mathrm{V} / \mathrm{Cr}$ values spanned a wide range with a maximum of 7.42 , a minimum of 1.42 , an average of 
2.95, and a standard deviation of 0.64 . There did not appear to be much change in $\mathrm{V} / \mathrm{Cr}$ ratios at the volcanic ash beds except for a decrease at B3 (299.21 feet/ 91.20 meters), and a decrease at the Crow Creek Member (455 feet/ 138.68 meters). Slight increases were found at around 480 feet, and the maximum value of 7.42 can be seen at a depth of 496.49 feet (151.33 meters) near the top of the Gregory Member. U/Th ratios showed variation with respect to the volcanic ash beds and the Crow Creek Member. Values had a maximum of 0.90, a minimum of 0.16, an average of 0.30 , and a standard deviation of 0.093 . The highest $\mathrm{U} / \mathrm{Th}$ value $(0.90)$ occurred at the base of the Crow Creek Member at 455 feet. The highest variation in the U/Th curve was seen at all volcanic ash beds as well as throughout the Gregory Member (455 to 512 feet/ 138.68 to 156.06 meters). $\mathrm{Mo} / \mathrm{Al}$ ratios were extremely low with a maximum of 0.0002 , a minimum of 6.97E-6, an average of $2.98 \mathrm{E}-5$, and a standard deviation that is higher than the average at $3.26 \mathrm{E}-$ 5. There were no visible Mo/Al fluctuations. Mo content was below the detection limit for all samples. 


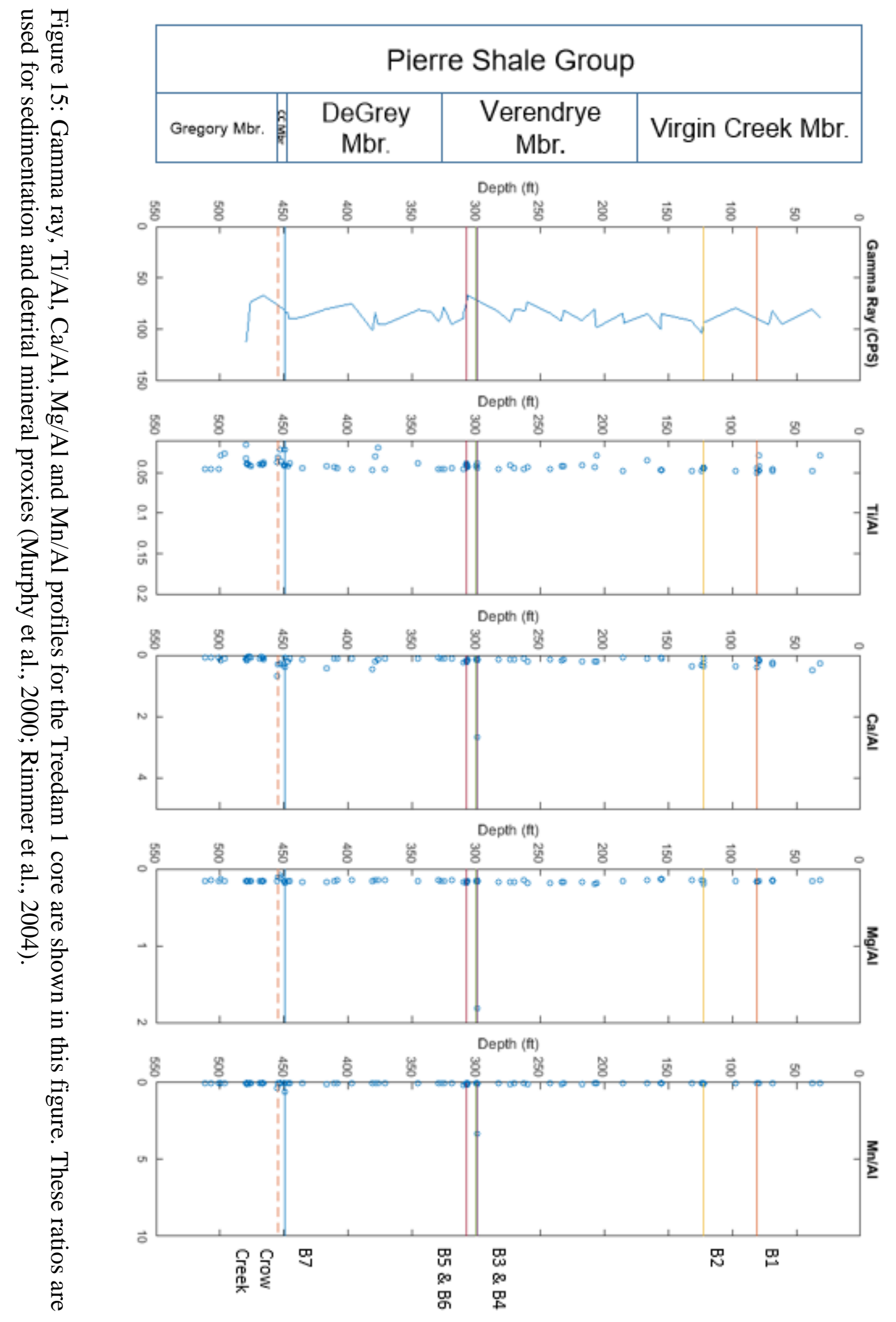




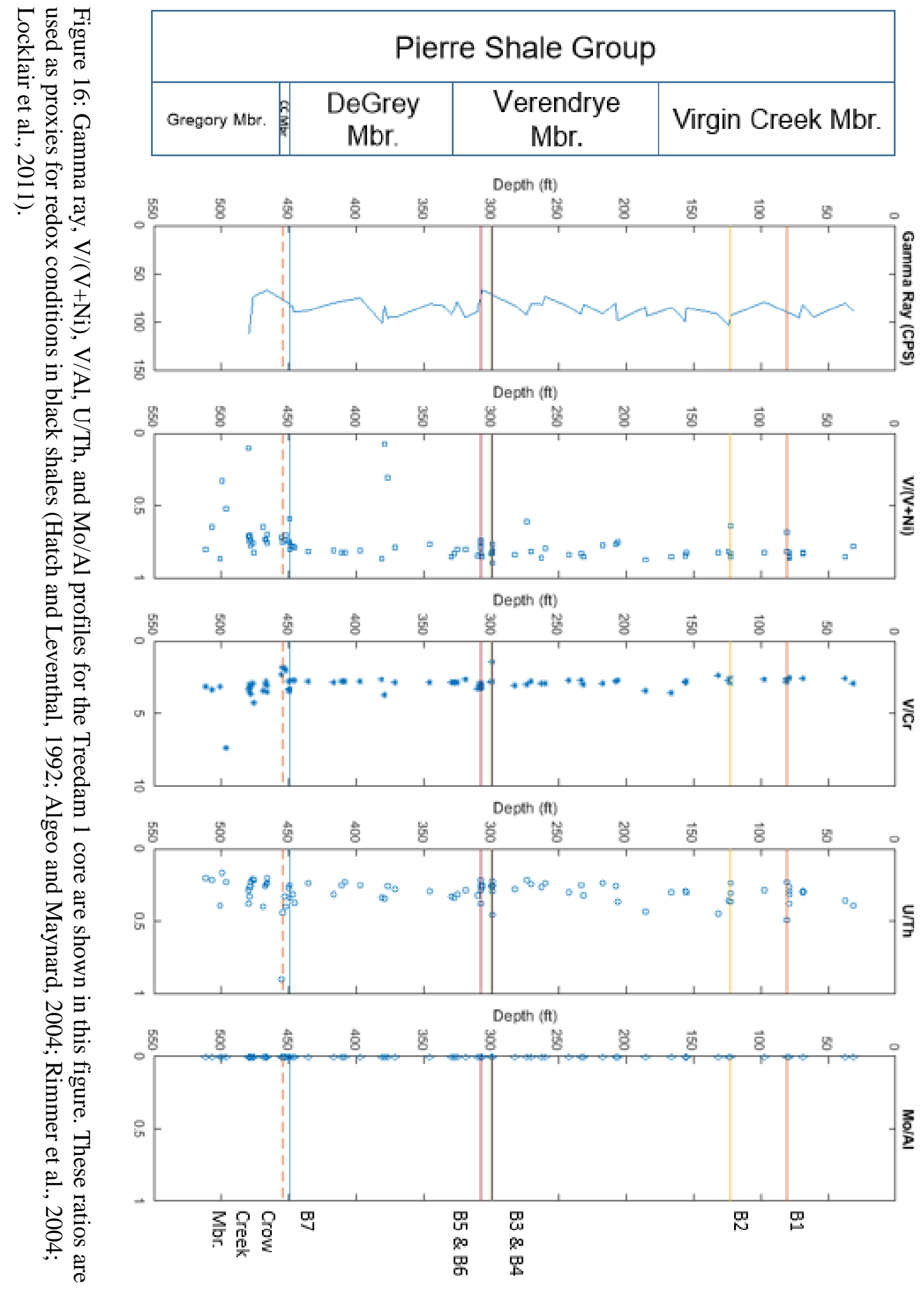




\subsection{Volcanic Ash Geochemical Trends and Statistical Analyses}

\subsubsection{Volcanic Ash Stable Isotope, TOC, and C/N Scatter Plots}

Carbonate and organic $\delta^{13} \mathrm{C}$ values, $\delta^{15} \mathrm{~N}$ values, \% TOC values, and $\mathrm{C} / \mathrm{N}$ values were plotted for all volcanic ash beds and changes in geochemical signatures were compared with the distance above volcanic ash bed deposition (see Figures 17 a through $17 \mathrm{e}$ ). All $\delta^{13} \mathrm{C}$ org values ranged between -27.5 and $-26.2 \%$. The organic $\delta^{13} \mathrm{C}$ values (shown in Figure 17a) did not show any major fluctuations within one foot of volcanic ash bed deposition. There may have been a decrease in $\delta^{13}$ Corg values 1.5 to 2 feet ( 0.45 to 0.6 meters) above ash deposition, but there was not enough data to draw any conclusions. Values for carbonate $\delta^{13} \mathrm{C}$ above each volcanic ash bed ranged between -9 and $+2 \%$ and are shown in Figure $17 \mathrm{~d}$. There was an increase in $\delta^{13}$ Ccarb for all samples within 1.5 feet ( 0.45 meters) of ash deposition. Post-volcanic ash nitrogen isotope changes are shown in Figure $17 \mathrm{~b}$. Values ranged from -2 to $+2.5 \%$ and showed fluctuating $\delta^{15} \mathrm{~N}$ signals within and above the volcanic ash bed. Fewer samples were taken from below the volcanic ash beds to focus on up-section geochemical changes resulting from ash deposition. These $\delta^{15} \mathrm{~N}$ patterns were consistent with the fluctuating patterns found throughout the core. Samples had values between -2 and $1 \%$ within one foot ( 0.30 meters), a normal range for atmospheric nitrogen isotope signatures. There were no apparent trends and the isotopic signals diverged from each other above 1 foot ( 0.30 meters) for all volcanic ash beds. The variance in values seemed to increase with distance above ash bed deposition. Total organic carbon content within and above each volcanic ash bed was plotted in Figure 17c. Values ranged from 0 to 1.75 $\%$ TOC content. The \% TOC signals do not change for each volcanic ash over time, indicating that ash deposition may not have contributed to an increase in \% TOC even within one foot of deposition. 


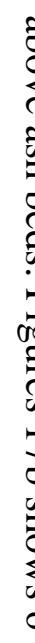

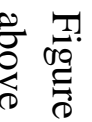

ڤี

ఠ T.

क

TI

बำ

유 를

긍

年

¿

क s :

u

$-8$

ऽิ

号

$\sum_{\infty}^{\circ}$

วิ

응

$\int \frac{1}{2}$

चै

एँ

\&

os 8

ผे

กิ

б

ڤ

อ คิ

긍

绾

\&?

$\Omega$ (T)

Z

苛. 光

\& is

ㅇํㅇ

造

م

है

尺
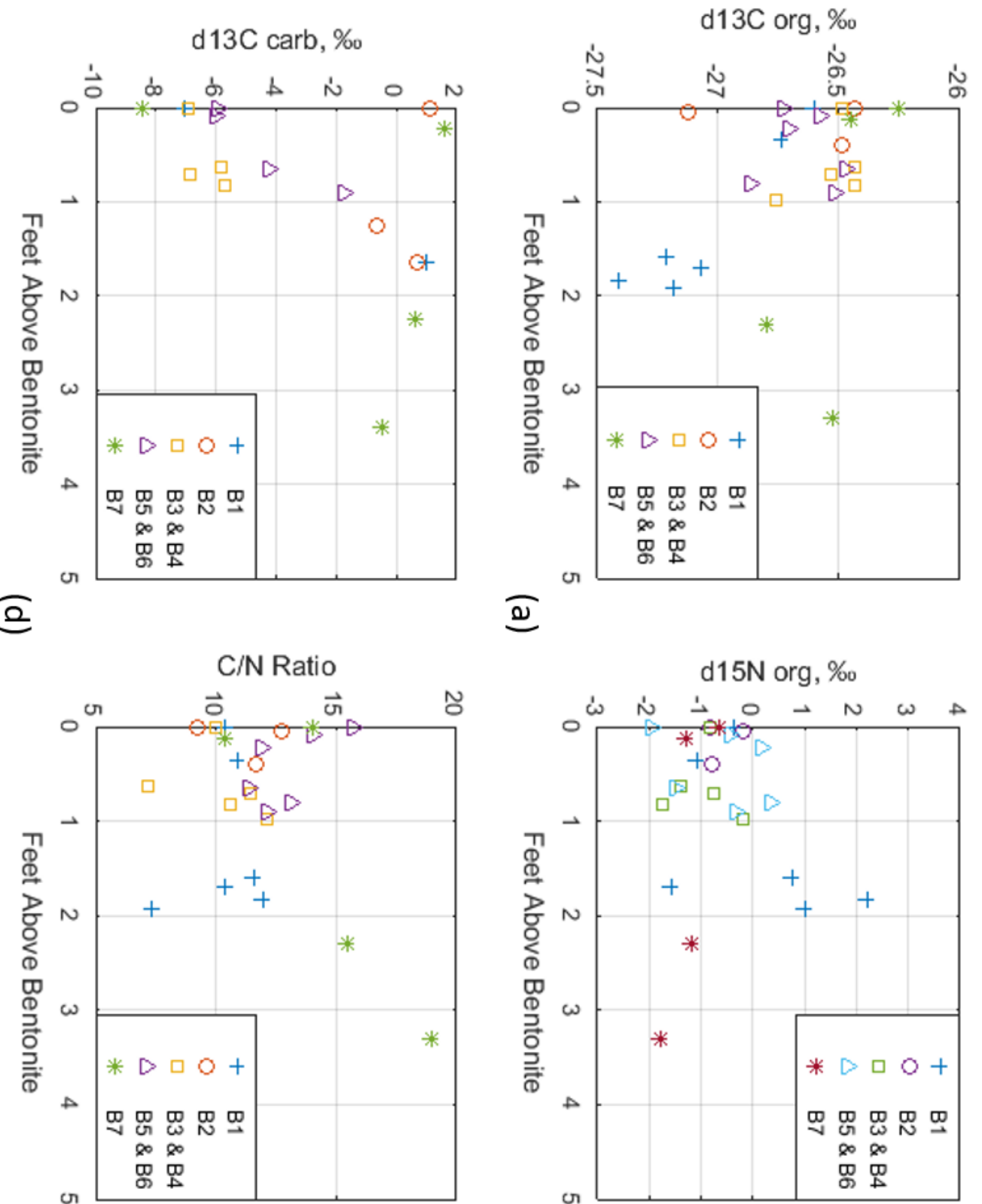

D
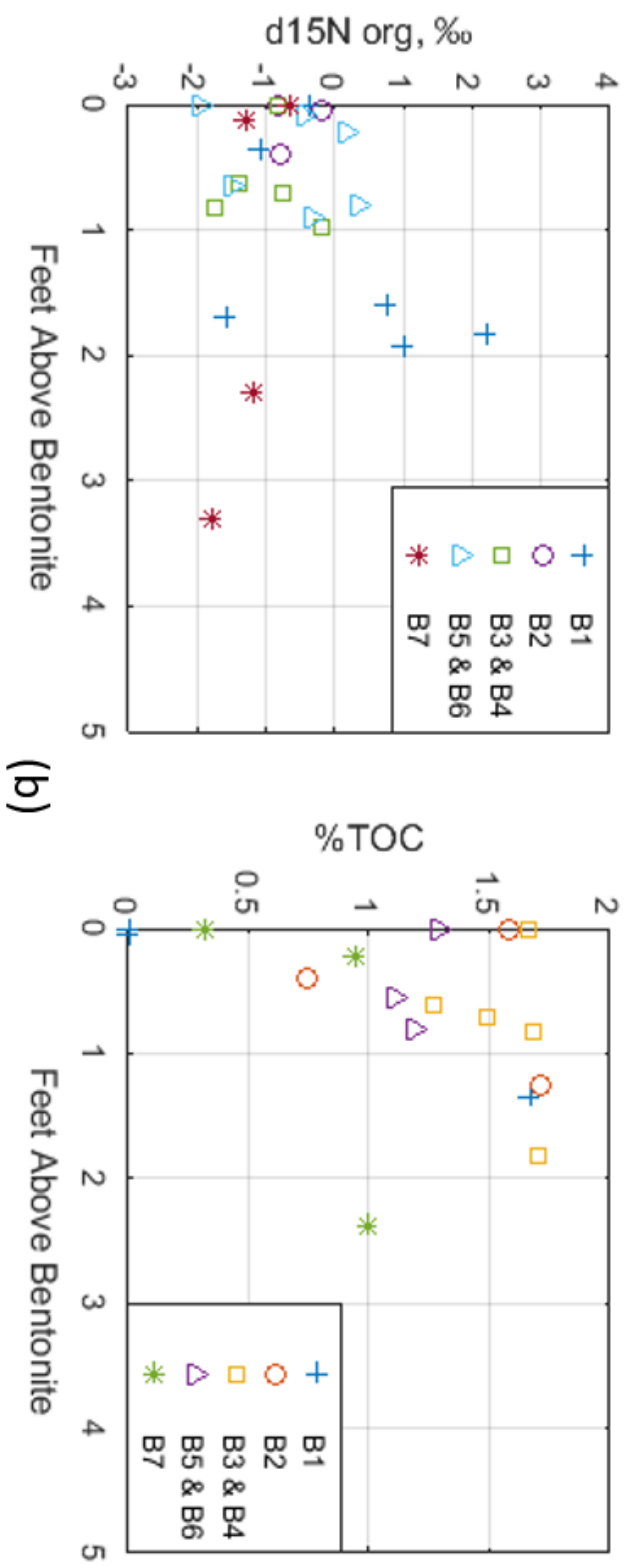

$\bar{c}$ 
The carbon/nitrogen weight percent content ratios within five feet (1.52 meters) of volcanic ash bed deposition are shown in Figure 17e. Values ranged from 7 to 16 and there were no trends evident in the scatter plots. Marine $\mathrm{C} / \mathrm{N}$ values range from 4-10 while terrestrial are usually >20 (Khan et al., 2015). All values above volcanic ash beds indicate a shallow marine source as many lie between 10 and 20 with an average of 12.05 (Khan et al., 2015).

\subsubsection{Volcanic Ash Trace Element Scatter Plots}

Figure 18 shows scatter plots of clastic input and sedimentation rate proxies at and above volcanic ash bed deposition (Murphy et al., 2000; Rimmer et al., 2004). Figure 18a shows Ti/Al ratios, Figure $18 \mathrm{~b}$, shows $\mathrm{Ca} / \mathrm{Al}$ ratios, Figure $18 \mathrm{c}$ shows $\mathrm{Mg} / \mathrm{Al}$ ratios, and Figure $18 \mathrm{~d}$ shows $\mathrm{Mn} / \mathrm{Al}$ ratios. More data is needed from below the volcanic ash beds to assess overall changes in shale geochemistry. Sedimentation and clastic input did not appear to be affected by ash bed deposition based on the trends shown in figures 18a through 18d. For the available data, there were no obvious trends or consistent changes in any clastic influx proxies for all volcanic ash beds.

$\mathrm{Ti} / \mathrm{Al}$ values had an overall standard deviation of $0.01, \mathrm{Ca} / \mathrm{Al}$ values had a standard deviation of $0.29, \mathrm{Mg} / \mathrm{Al}$ values had a standard deviation of 0.18 , and $\mathrm{Mn} / \mathrm{Al}$ values had a standard deviation of 0.36 . All sample variations observed in Figure 18 were likely due to sample error as all results were within one standard deviation of the total sample data.

Trace element proxies were used to identify changes in redox conditions post-volcanic ash deposition (Figures 19a through 20d). Figure 19a shows V/(V+Ni) ratios which were used as 


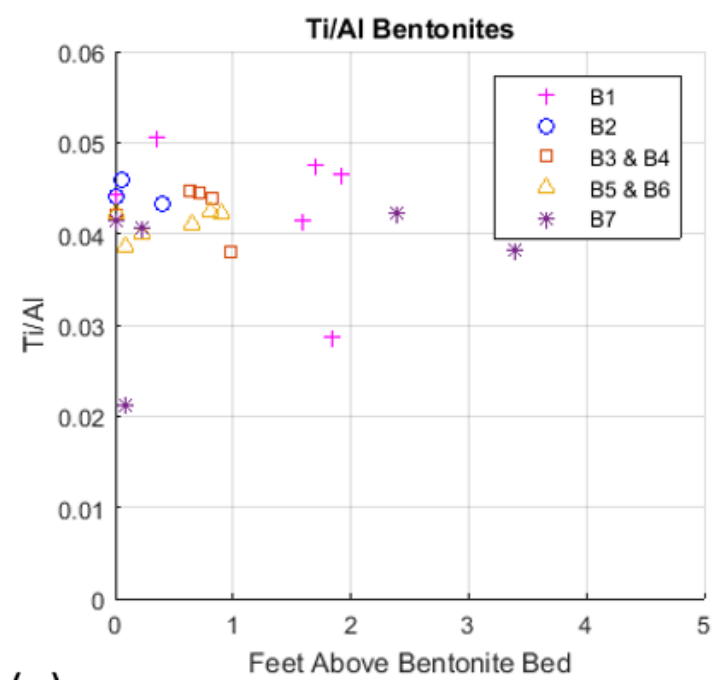

(a)

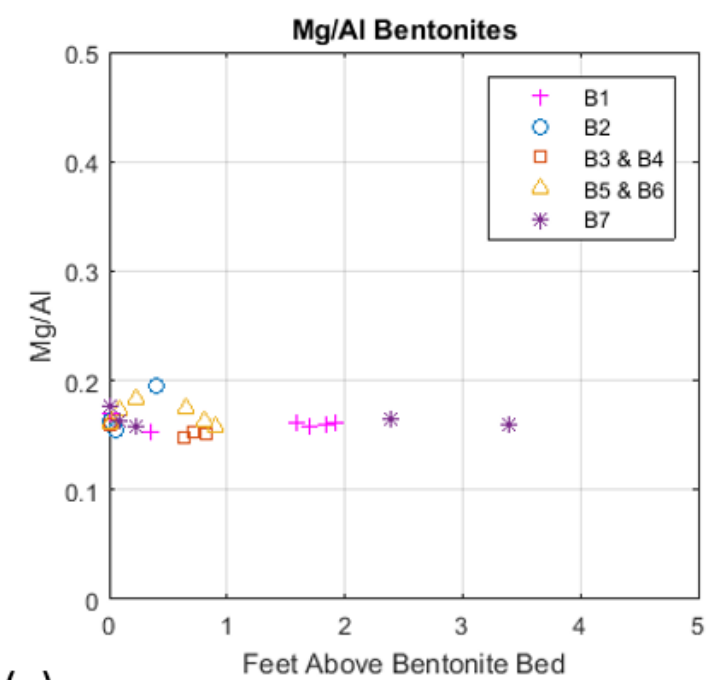

(c)

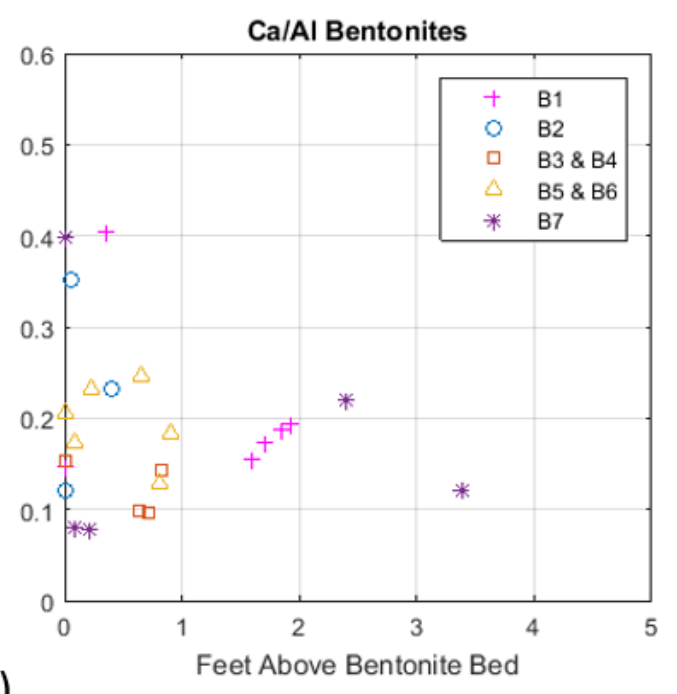

(b)

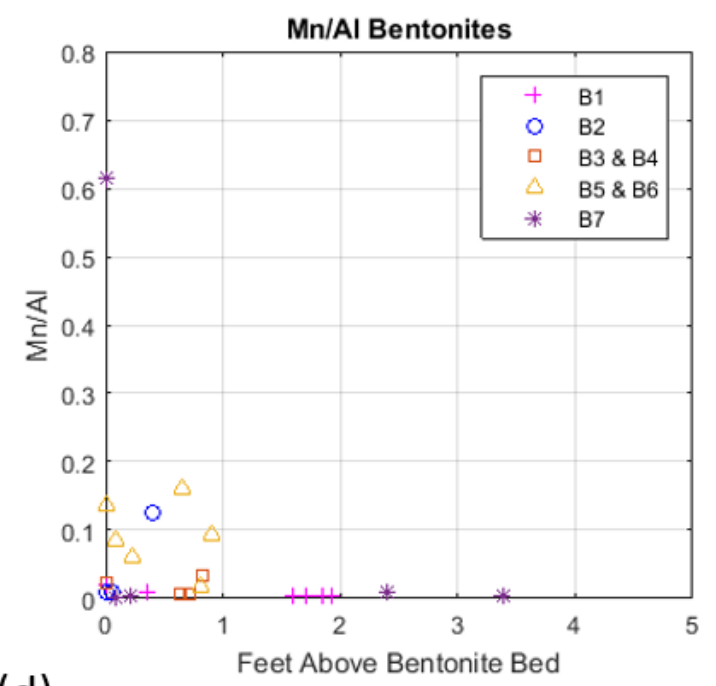

(d)

Figure 18: Figures 18a through 18d show proxies for clastic influx and carbonate content.

proxies for anoxia and reducing conditions (Hatch and Leventhal, 1992; Algeo and Maynard, 2004; Rimmer et al., 2004; Locklair et al., 2011). Figure 19b shows V/Cr ratios which were used to eliminate detrital influence from the vanadium input signatures (Tribovillard et al., 2016).

Figure 19c and 19d show U/Th and Mo/Al ratios which were also proxies for reducing conditions (Hatch and Leventhal; 1992; Algeo and Maynard, 2004). Most samples in Figure 19a 
show a shift from euxinic environments $(\mathrm{V} /(\mathrm{V}+\mathrm{Ni})$ ratios $>0.84)$ to anoxic environments $(\mathrm{V} /(\mathrm{V}+\mathrm{Ni})$ ratios 0.82 to 0.54$)$ (Hatch and Leventhal, 1992).
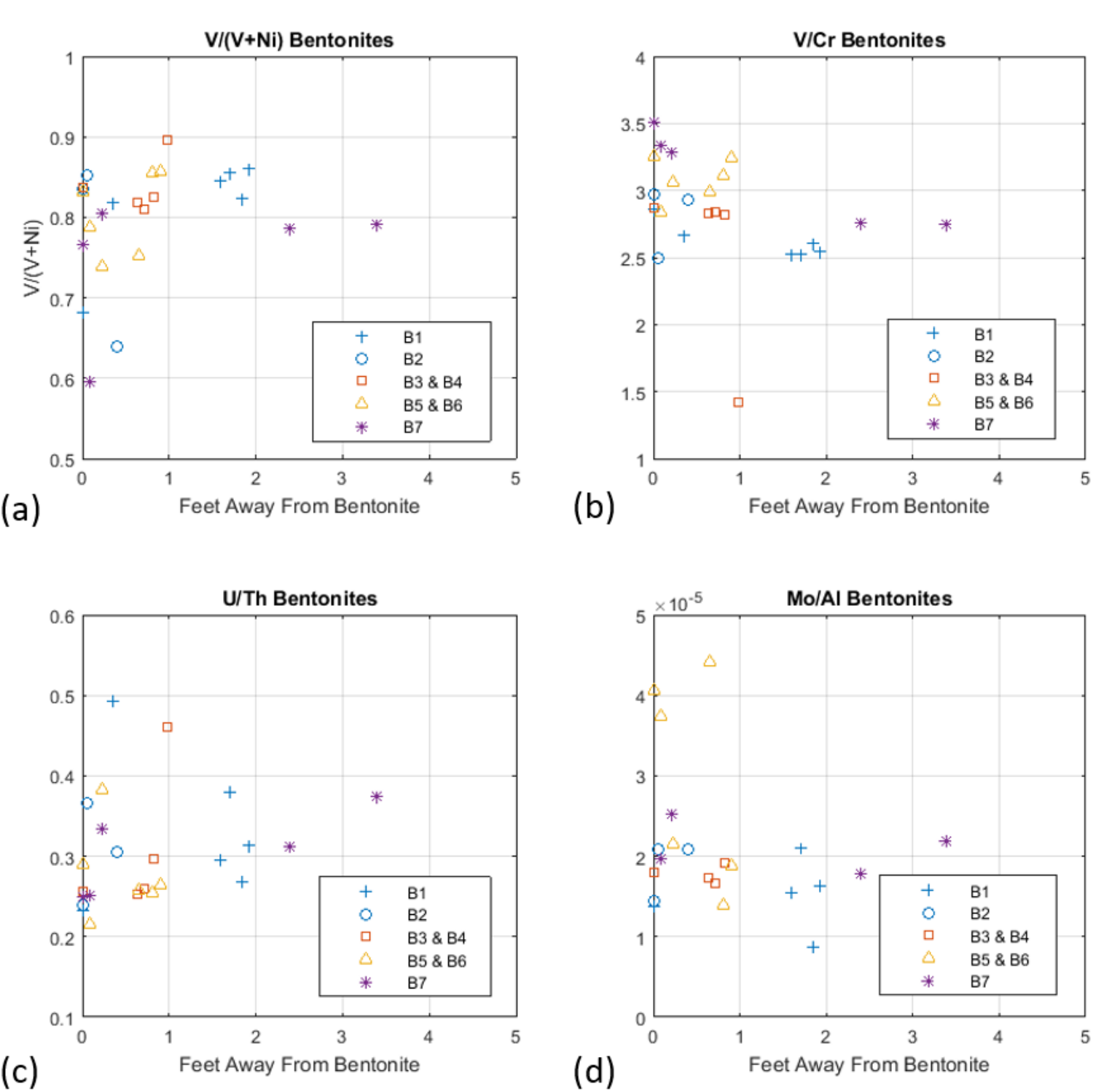

(b)

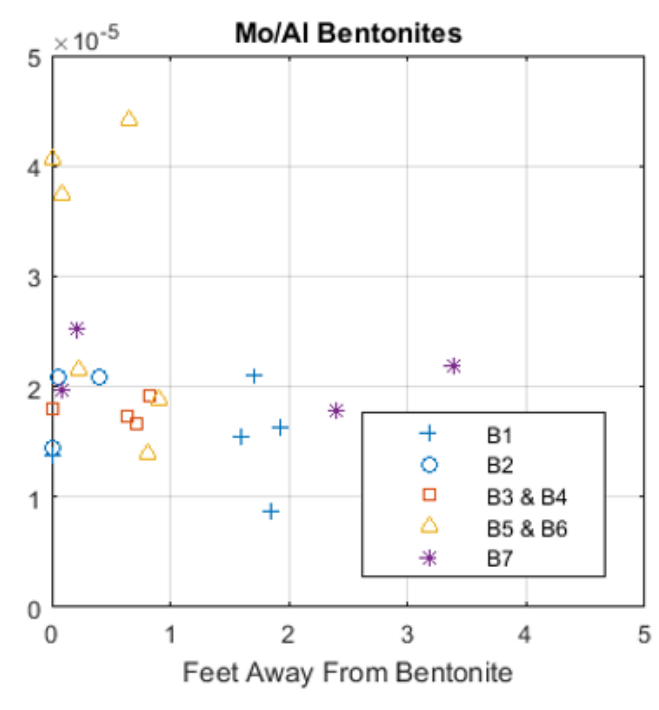

Figure 19: Figures 19a through 19d represent trace element ratios above each bentonite layer in the Treedam 1 core. Each elemental ratio is used as a proxy for redox conditions during shale deposition. 


\subsubsection{Volcanic Ash Statistical Analyses}

Results for the volcanic ash bed $\mathrm{z}$ and t-tests are shown in Table 4 and Table 5. Twotailed p-values were calculated using online software published by Harvey Motulsky (2016). Tstatistics were used instead of Z-statistics for $\% \mathrm{TOC}, \delta^{13} \mathrm{C}$ carb, and all trace element data because the number of samples was less than thirty. P-values for all geochemical parameters show that the differences between overall Treedam values and those in the volcanic ash beds were not statistically significant.

\begin{tabular}{|c|c|c|c|c|c|c|c|}
\hline $\begin{array}{c}\text { Statistical } \\
\text { Value }\end{array}$ & $\begin{array}{c}\delta 13 C \\
(\% 0)\end{array}$ & $\delta 15 \mathrm{~N}(\%)$ & $\mathbf{N} \%$ & $\mathrm{C} \%$ & $\mathbf{C} / \mathbf{N}$ & $\% \mathrm{TOC}$ & $\begin{array}{l}\delta 13 C \\
\text { Carb }\end{array}$ \\
\hline $\begin{array}{c}\text { Treedam Core } \\
\text { Total Mean } \\
(\mu)\end{array}$ & -26.59 & -0.54 & 0.06 & 0.70 & 11.90 & 1.22 & -2.59 \\
\hline $\begin{array}{c}\text { Number of } \\
\text { Volcanic ash } \\
\text { Samples (N) }\end{array}$ & 30 & 30 & 30 & 30 & 30 & 19.00 & 18.00 \\
\hline $\begin{array}{l}\text { Volcanic ash } \\
\text { Sample Mean } \\
\text { (x) }\end{array}$ & -26.68 & -0.60 & 0.07 & 0.83 & 11.81 & 1.19 & -3.02 \\
\hline $\begin{array}{c}\text { Volcanic ash } \\
\text { Standard } \\
\text { Deviation }(\sigma)\end{array}$ & 0.32 & 0.97 & 0.03 & 0.25 & 2.45 & 0.55 & 3.55 \\
\hline Z-score & 0.29 & 0.07 & -0.48 & -0.51 & -0.01 & - & - \\
\hline t-score & - & - & - & - & - & 0.06 & 0.12 \\
\hline $\mathrm{p}$-value & 0.7716 & 0.9441 & 0.6348 & 0.6109 & 0.9912 & 0.9516 & 0.905 \\
\hline
\end{tabular}

Table 4: This table shows all values used to calculate the $\mathrm{t}$ and $\mathrm{z}$ scores for volcanic ash organic geochemical proxies (equation 3). 


\begin{tabular}{|c|c|c|c|c|c|c|c|c|}
\hline $\begin{array}{c}\text { Statistical } \\
\text { Value }\end{array}$ & Ti/Al & $\mathrm{Ca} / \mathrm{Al}$ & Mg/Al & $\mathbf{M n} / \mathbf{A l}$ & $\mathrm{V} /(\mathrm{V}+\mathbf{N i})$ & $\mathrm{V} / \mathrm{Cr}$ & U/Th & Mo/A \\
\hline $\begin{array}{l}\text { Treedam } \\
\text { Core Total } \\
\text { Mean }(\mu)\end{array}$ & 0.04 & 0.21 & 0.18 & 0.08 & 0.76 & 2.95 & 0.30 & $\begin{array}{c}2.98 \mathrm{E}- \\
05\end{array}$ \\
\hline $\begin{array}{c}\text { Number of } \\
\text { Volcanic ash } \\
\text { Samples (N) }\end{array}$ & 26.00 & 26.00 & 26.00 & 26.00 & 26.00 & 26.00 & 26.00 & 24.00 \\
\hline $\begin{array}{c}\text { Volcanic ash } \\
\text { Sample } \\
\text { Mean (x) }\end{array}$ & 0.04 & 0.29 & 0.23 & 0.19 & 0.80 & 2.84 & 0.30 & $\begin{array}{c}2.84 \mathrm{E}- \\
05\end{array}$ \\
\hline $\begin{array}{l}\text { Volcanic ash } \\
\text { Standard } \\
\text { Deviation } \\
(\sigma)\end{array}$ & 0.01 & 0.49 & 0.32 & 0.65 & 0.08 & 0.40 & 0.07 & 0.00 \\
\hline t-score & 0.15 & 0.16 & 0.16 & 0.17 & 0.44 & -0.27 & -0.09 & -0.04 \\
\hline $\mathrm{p}$-value & 0.88 & 0.87 & 0.88 & 0.87 & 0.66 & $\begin{array}{c}0.786 \\
3\end{array}$ & 0.93 & 0.97 \\
\hline
\end{tabular}

Table 5: This table shows all values used to calculate the $\mathrm{t}$ and $\mathrm{z}$ scores for the volcanic ash trace element geochemical proxies (equation 3).

\subsection{Crow Creek Geochemical Trends and Statistical Analysis}

\subsubsection{Crow Creek Member Stable Isotope, TOC, and C/N Scatter Plots}

Geochemical changes from below and above the Crow Creek Member deposition are shown in figures $20 \mathrm{a}$ through $\mathrm{d}$. The value 0 on the $\mathrm{X}$-axis indicates the basal Crow Creek contact depth. Positive numbers on the $\mathrm{X}$-axis indicate feet up-section from the Crow Creek, while negative numbers indicate feet down-section from the Crow Creek. 


\section{Crow Creek Stable Isotopes and \%TOC vs. Depth}
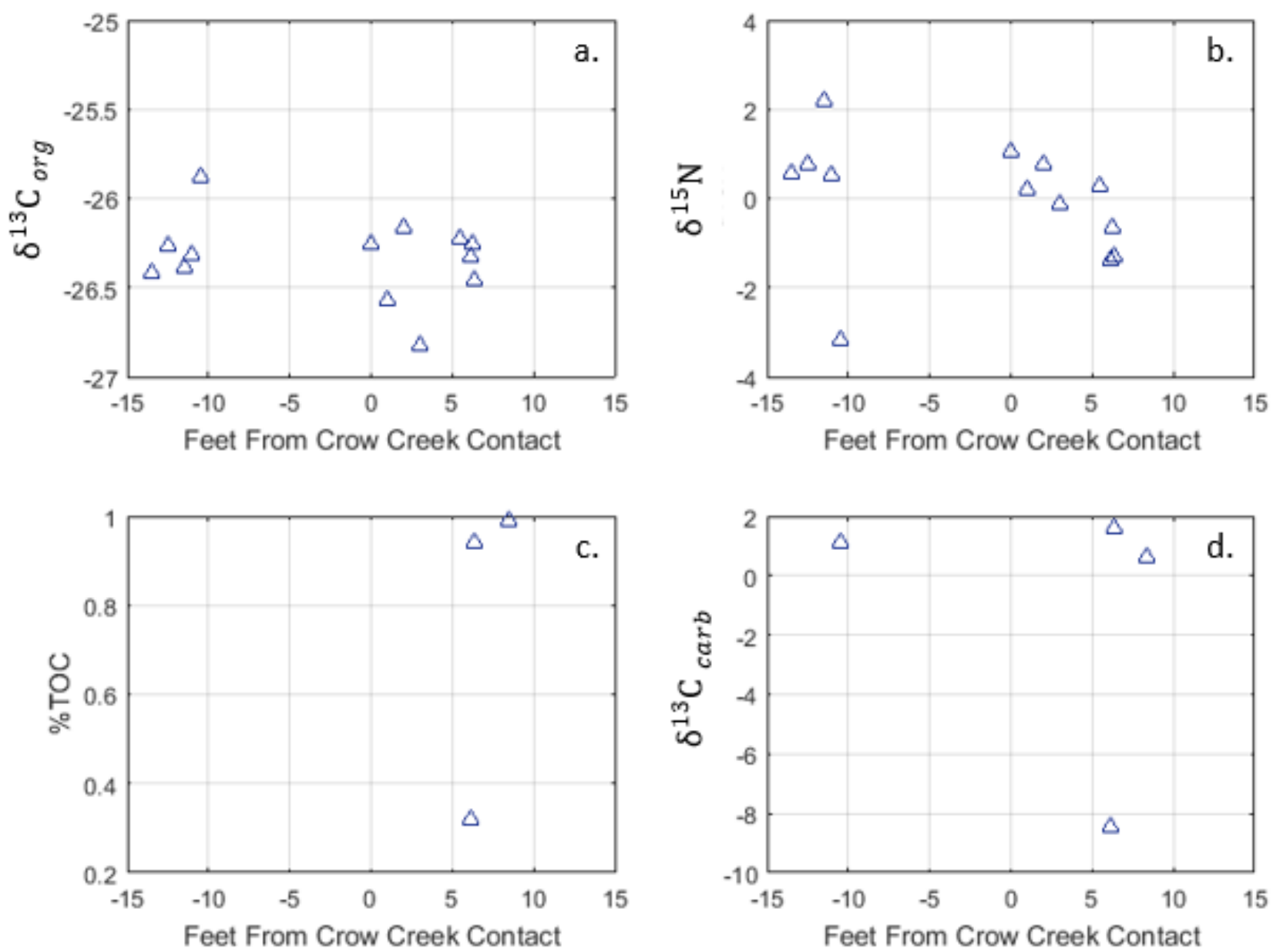

Figure 20: Crow Creek Member $\delta^{13} C$ carb, $\delta^{13} C$ org, $\delta^{15} N$, and TOC are represented in this figure. Sample size was limited for $\%$ TOC and $\delta^{13} C$ carb so the scale was expanded to include samples from 25 feet (7.62 meters) below the Crow Creek contact.

Figure 20a shows organic $\delta^{13} \mathrm{C}$ values plotted against feet above and below the Crow Creek Member deposition. Values ranged between -25.75 and -26.5\% below the Crow Creek, and between -27 and $-26 \%$ above the Crow Creek. There was too much scatter and not enough data in the organic carbon isotope data to identify any clear trends. Figure 20b shows carbonate $\delta^{13} \mathrm{C}$ values plotted against depth above and below the Crow Creek Member. There were not enough carbonate isotope data points to distinguish any visible trends. 
Organic $\delta^{15} \mathrm{~N}$ values exhibited a slight negative trend after the deposition of the Crow Creek Member (Figure 20c). Values sank from +1 to $+2 \%$ prior to Crow Creek deposition to -1 to $-2 \%$ post-Crow Creek deposition. Figure $20 \mathrm{~d}$ shows weight percent total organic carbon values from before and after the deposition of the Crow Creek Member. There are not enough data from within and immediately above and below the Crow Creek Member to confirm that there is an increase in \% TOC after the deposition of the Crow Creek Member.

\subsubsection{Crow Creek Trace Element Scatter Plots}

Figure 21a through $21 \mathrm{~h}$ show trace element geochemical proxies before and after the deposition of the Crow Creek Member. Figure 21a shows a sharp decrease in Ti/Al ratios within the Crow Creek Member, and in B7 immediately above the Crow Creek Member. Figure 21b shows an increase in $\mathrm{Ca} / \mathrm{Al}$ at the base of the Crow Creek contact and then a decrease to around 0.30 within the rest of the Crow Creek Member. Figure 21c shows $\mathrm{Mg} / \mathrm{Al}$ ratios decreasing only within the Crow Creek Member to almost 0.075 and then increasing to baseline levels at around 0.15. Figure 21d shows $\mathrm{Mn} / \mathrm{Al}$ ratios that have a low average at 0.020 , but these levels increase to 0.35 at the base of the Crow Creek Member before returning to 0.020 throughout the other three feet (0.91 meters) of the Crow Creek Member.

Figure 21e shows $\mathrm{V} /(\mathrm{V}+\mathrm{Ni})$ ratios fluctuating around 0.7 , similar to baseline values throughout the Crow Creek Member, and then declining in the middle of the B7 volcanic ash bed at the top of the Crow Creek. Figure 21f shows a drastic decline from 3.5 to $1.7 \mathrm{in} \mathrm{V} / \mathrm{Cr}$ ratios beginning at the base of the Crow Creek Member and increasing back to 3.5 just above the upper contact of the Crow Creek Member. Figure 21g shows a brief increase in U/Th values from 0.2 to 0.9 at the base of the Crow Creek Member. The values return to 0.2 in the upper three feet (0.91 meters) of the Crow Creek Member. Figure 21h shows Mo/Al values, which are depleted 
throughout the Treedam core, increasing at the base of the Crow Creek Member, and returning to previous background values post-Crow Creek Member deposition, however the scale is likely showing noise in the data. 


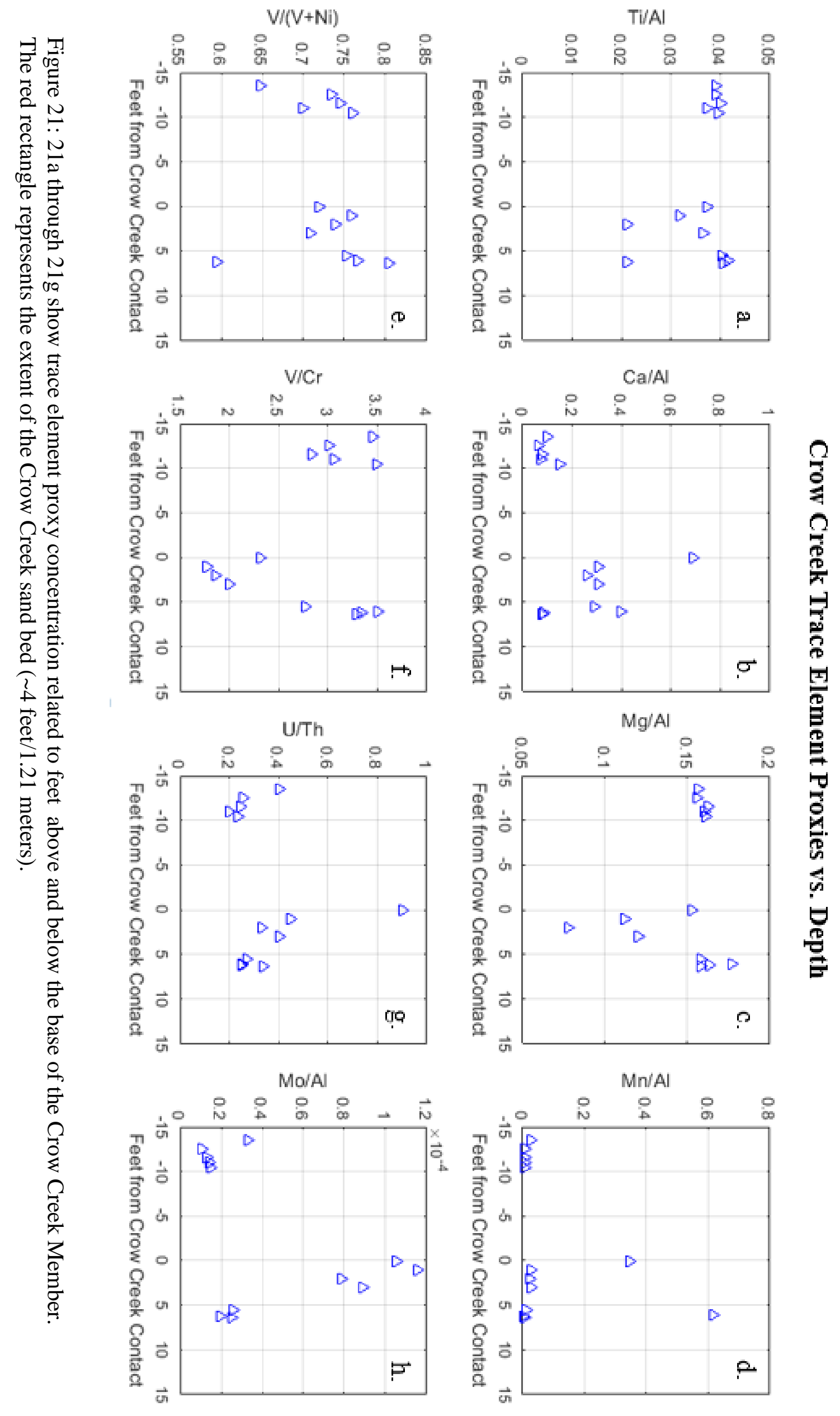




\subsubsection{Crow Creek Statistical Analyses}

Results for the Crow Creek t-tests are shown in Table 6 and Table 7. Two-tailed p-values were calculated using online software published by Motulsky (2016). P-values were not calculated for \% TOC or $\delta^{13} \mathrm{C}$ carb because there were not enough samples for those proxies to perform accurate analyses on them. P-values for all geochemical parameters show that the differences between overall Treedam values and those in the Crow Creek were not statistically significant.

\begin{tabular}{|c|c|c|c|c|c|}
\hline Statistical Value & $\delta 13 C$ & $\delta 15 N$ & $\mathbf{N} \%$ & $\mathrm{C} \%$ & $\mathbf{C} / \mathbf{N}$ \\
\hline $\begin{array}{c}\text { Treedam Core Total } \\
\text { Mean }(\mu)\end{array}$ & -26.59 & -0.54 & 0.06 & 0.70 & 11.90 \\
\hline $\begin{array}{l}\text { Number of Crow } \\
\text { Creek Samples (N) }\end{array}$ & 5.00 & 5.00 & 5.00 & 5.00 & 5.00 \\
\hline $\begin{array}{c}\text { Crow Creek Sample } \\
\text { Mean (x) }\end{array}$ & -26.41 & -0.64 & 0.04 & 0.42 & 11.84 \\
\hline $\begin{array}{c}\text { Crow Creek Standard } \\
\text { Deviation }(\sigma)\end{array}$ & 0.28 & 0.66 & 0.03 & 0.30 & 3.11 \\
\hline t-score & 0.62 & -0.14 & -0.74 & -0.92 & -0.02 \\
\hline p-value & 0.72 & 0.45 & 0.25 & 0.21 & 0.49 \\
\hline
\end{tabular}

Table 6: This table shows all values used to calculate the $\mathrm{t}$ and $\mathrm{z}$ scores for the Crow Creek organic geochemical proxies (equation 3). 


\begin{tabular}{|c|c|c|c|c|c|c|c|c|}
\hline $\begin{array}{l}\text { Statistical } \\
\text { Value }\end{array}$ & $\mathbf{T i} / \mathbf{A l}$ & $\mathrm{Ca} / \mathrm{Al}$ & Mg/Al & Mn/Al & $\mathbf{V} /(\mathbf{V}+\mathbf{N i})$ & $\mathrm{V} / \mathrm{Cr}$ & U/Th & Mo/Al \\
\hline $\begin{array}{l}\text { Treedam } \\
\text { Core Total } \\
\text { Mean }(\mu)\end{array}$ & 0.04 & 0.21 & 0.18 & 0.08 & 0.76 & 2.95 & 0.30 & 0.00 \\
\hline $\begin{array}{l}\text { Number of } \\
\text { Crow Creek } \\
\text { Samples } \\
\text { (N) }\end{array}$ & 8.00 & 8.00 & 8.00 & 8.00 & 8.00 & 8.00 & 8.00 & 7.00 \\
\hline $\begin{array}{c}\text { Crow Creek } \\
\text { Sample } \\
\text { Mean (x) }\end{array}$ & 0.03 & 0.30 & 0.14 & 0.13 & 0.73 & 2.61 & 0.40 & 0.00 \\
\hline $\begin{array}{c}\text { Crow Creek } \\
\text { Standard } \\
\text { Deviation } \\
(\sigma)\end{array}$ & 0.01 & 0.20 & 0.05 & 0.22 & 0.07 & 0.75 & 0.22 & 0.00 \\
\hline t-score & -0.66 & 0.45 & -0.76 & 0.25 & -0.48 & -0.46 & 0.43 & 0.67 \\
\hline p-value & 0.53 & 0.67 & 0.47 & 0.81 & 0.64 & 0.66 & 0.68 & 0.53 \\
\hline
\end{tabular}

Table 7: This table shows all values used to calculate the $\mathrm{t}$ and $\mathrm{z}$ scores for the volcanic ash trace element geochemical proxies (equation 3). 


\section{CHAPTER 5: DISCUSSION}

\subsection{Mineralogy of Volcanic Ash Beds}

$\mathrm{X}$-Ray diffraction analysis combined with core log lithology notes confirmed the presence of quartz and montmorillonite in the ash layers. The XRD pattern for montmorillonite was similar to that of muscovite, however montmorillonite is a clay, and muscovite is an ordered mineral. The abundance of smaller peaks in the XRD pattern indicated that the peaks were from a clay mineral, supporting the claim that all selected volcanic ash beds contained montmorillonite. The peaks in the Treedam sample data also closely matched montmorillonite $\mathrm{x}$ ray diffraction values in other studies, which are $2 \theta_{060}\left(\mathrm{CuK}_{\alpha}\right)=62.22-61.67^{\circ}$ for which the $d_{060}$ ranged from 1.492 to $1.504 \AA$ (Moore and Reynolds, 1989, p. 224). The lowest peak between $5^{\circ}$ and $10^{\circ}$ representing montmorillonite corresponded with volcanic ash mineralogy X-ray diffraction peaks listed by Kooli, indicating the hydrated portion of the clay as two layers of water (2013). Other XRD analyses on volcanic ash mineralogy also showed similar X-ray diffraction curves at the low $2 \theta$ angle for montmorillonite (Oueslati et al., 2011; Kooli, 2013).

\subsection{Total Organic Carbon, $\delta^{13} \operatorname{Corg}$, and $\delta^{13}$ Carb}

\subsection{1 $\delta^{13}$ Corg values and \%TOC}

The shift in organic carbon $\delta^{13} \mathrm{C}$ signals of the Treedam core (on average between -26 and $-28 \%$ ) compared with previous studies suggesting that the Cretaceous Western Interior Seaway in South Dakota was mostly brackish water, or a mixture of salt and freshwater (Patrick et al., 2004). The low $\delta^{13} \mathrm{C}$ signature has usually suggested high amounts of terrestrial/freshwater input, which may indicate shallow sea depths and close proximity to land; however, average $\delta^{13} \mathrm{C}$ values of the Western Interior Seaway were much more negative than present day values and range from -28 to $-27 \%$, which average -26 \%o for the Cretaceous Period (Kashiyama et al., 
2008). The fact that $\delta^{13} \mathrm{C}$ values on average were lower than modern day times suggest that an increase in global atmospheric $\mathrm{CO}_{2}$ from increased volcanism was the cause for these depleted values (Brady et al., 2013; Calvert et al., 1996).

The total organic carbon (TOC) data ranged from $0.01 \%$ to $1.83 \%$ with an average of $1.22 \%$ (see figure 14). Percent TOC values in the Gregory Member showed a decreasing trend in TOC (from 1.25 to $0.3 \%$ ) throughout the Crow Creek Member and up into the Gregory Member, where values increased from $0.3 \%$ to $1 \%$ TOC. There was very little variation in organic carbon content throughout the core. This trend may indicate a delayed increase in organic matter generation and preservation within the water column caused by the influx of organic matter caused by the Manson impact, or it could be evidence of enhanced organic matter preservation caused by the Bearpaw Cyclothem marine transgression. Overall \% TOC content in the Pierre shale is low for this locality.

\subsection{2 $\delta^{13}$ Ccarb values}

Average carbonate $\delta^{13} \mathrm{C}$ values for the Treedam core were $-2.9 \%$ with a maximum of $1.7 \%$ and a minimum of $-10.9 \%$. Enriched $\delta^{13} \mathrm{C}$ values only occurred in two sections of the Treedam core: The first section is at the base of the Treedam core. $\delta^{13} \mathrm{C}$ values rise above $0 \%$ at 466 feet (142.03 meters) and at 450 feet (137.16 meters) just above the Crow Creek Member. The second section enriched in $\delta^{13} \mathrm{C}$ carb was throughout the Virgin Creek Member from 160 feet (48.76 meters) to around 30 feet (9.14 meters), with the exception of the B1 samples. The majority of Virgin Creek $\delta^{13}$ Carb values oscillated between -1 and $+1 \%$. There did not appear to be much change within these regions with elevated values, however they were the only regions in the Treedam core where marine $\delta^{13} \mathrm{Ccarb}$ isotope signatures were within range for marine carbonates (Jenkyns et al., 2001). 
The depleted carbonate isotope values could have been caused by several factors. The first factor considered was terrestrial input. Values for $\delta^{13} \mathrm{C}$ carb could be influenced by the addition of isotopically depleted groundwater and surface water, which retain depleted terrestrial signatures (Chen and Sharma, 2016). Depleted bulk carbon isotope values (below $0 \%$ ) could also have indicated recycling of waters with highly oxidized organic matter content (Jenkyns et al., 2001).

\subsection{Nitrogen Isotopes}

The Treedam $\delta^{15} \mathrm{~N}$ isotope ratios ranged between $-5.6 \%$ and 2.2\%o (Figure 13). The majority of nitrogen isotope data had an average of $-0.5 \%$ and plotted near atmospheric $\mathrm{N}_{2}$ levels $(0 \%)$. There were two anomalous negative shifts that showed $\delta^{15} \mathrm{~N}$ values of $-5.6 \%$, and these were at depths of 499.28 feet (152.18 meters) and 378.95 feet (115.50 meters). Present day $\delta^{15} \mathrm{~N}$ values of subsurface nitrate range around 5\%, and the normal coastal range of $\delta^{15} \mathrm{~N}$ values caused by partial denitrification could average higher than 10\%o (Stüeken et al., 2015; Zhang et al., 2014; Wada et al., 1987). Diagenesis has been shown to cause an enrichment in $\delta^{15} \mathrm{~N}$ values (Sigman et al., 2009). The Treedam nitrogen isotope data, although from a coastal brackish marine environment, did not fall into normal coastal $\delta^{15} \mathrm{~N}$ ranges. Nitrogen fixation could explain the values close to $0 \%$, but not the negative excursions between -3 and $-5 \%$ in the lower section of the Treedam core (Quan et al., 2008; Calvert et al., 1996).

We considered several mechanisms to interpret overall trends in the Treedam $\delta^{15} \mathrm{~N}$ data. Slight negative shifts in $\delta^{15} \mathrm{~N}$ could have indicated $\mathrm{N}$-fixing phytoplankton activity, though this process has usually resulted in little isotope fractionation remaining at atmospheric $\delta^{15} \mathrm{~N}$ values of $(0 \%)$. The explanation for the depleted $\delta^{15} \mathrm{~N}$ value anomaly may be diazotrophs, bacteria and archaea that fix atmospheric nitrogen $\left(\mathrm{N}_{2}\right)$ into nitrate $\left(\mathrm{NO}_{3}^{-}\right)$or ammonia $\left(\mathrm{NH}_{4}^{+}\right)$by using 
nitrogenase enzyme pathways (Stüeken et al., 2015; Zhang et al., 2014; Zerkle et al., 2008).

Evidence of these atmospheric nitrogen fixers was found in low $\delta^{15} \mathrm{~N}$ values in marine sediment from Cretaceous Oceanic Anoxic Events as well as from Archean sediment (Zhang et al., 2014). Cretaceous $\delta^{15} \mathrm{~N}$ values have been shown to be more depleted than Quaternary $\delta^{15} \mathrm{~N}$ values because most organic matter deposited in Mesozoic marine environments was composed of $\mathrm{N}_{2^{-}}$ fixing cyanobacteria biomass (Jenkyns et al., 2007; Rau et al., 1987).

The Treedam core bulk $\delta^{15} \mathrm{~N}$ values fell within range of OAE II from the CenomanianTuronian boundary of the Cretaceous Period (-5 to $-2 \%$ for bulk N) (Jenkyns et al., 2007). Depleted fixed nitrogen in marine systems was shown to activate Mo-nitrogenase pathways in diazotrophs, allowing them to fix atmospheric $\mathrm{N}_{2}$ (Stüeken et al., 2015; Zhang et al., 2014; Zerkle et al., 2008). Mo-nitrogenase is the most efficient diazotoph nitrogen fixation pathway and has only reflected a $\delta^{15} \mathrm{~N}$ depletion of -2 to $-1 \%$. Other alternate nitrogenase enzymes fractionate nitrogen isotopes up to -4 \%o (Stüeken et al., 2015; Glass et al., 2010; Zerkle et al., 2008; Jenkyns et al., 2007; Ohkouchi et al., 2006; Kuyper et al., 2004; Rau et al., 1987). Molybdenum in the Mo-nitrogenase pathway is needed for $\mathrm{NO}_{3}^{-}$reduction to $\mathrm{NO}_{2}$ via nitrate reductase (Glass et al., 2010). According to a study by Glass, et al., there is a co-limitation between nitrogen and molybdenum content in seawater (2010). Molybdenum content is usually higher in seawater than in freshwater. Environments facing a nitrogen shortage tend to face a molybdenum shortage, forcing diazotrophs to use alternate nitrogenase pathways using iron (Anf) and vanadium (Vnf) (Stüeken et al., 2015; Zhang et al., 2014; Glass et al., 2010). These pathways have been shown to cause much more depleted $\delta^{15} \mathrm{~N}$ isotope values between -4\%o and 6\%o (Stüeken et al., 2015; ; Zhang et al., 2014; Glass et al., 2010; Zerkle et al., 2008). 
Since the $\delta^{15} \mathrm{~N}$ values in the Treedam range from +2 to $-6 \%$, we can deduce that these changes were likely influenced by nitrogen and molybdenum content in seawater. Molybdenum and nitrogen levels are depleted throughout the Treedam core. It is possible that there was a colimited nitrogen and molybdenum shortage in the Treedam locality causing cyanobacteria to use the Fe or V nitrogenase pathways (Zhang et al., 2013). However, the Fe-nitrogenase enzyme (Anf) is not found in cyanobacteria, so if the depleted nitrogen isotope signals were caused by cyanobacteria, then the pathways were likely Mo or V nitrogenase pathways (Glass et al., 2010). The $\delta^{15} \mathrm{~N}$ isotope values above 375 feet (114.3 meters) in the Treedam core are much less depleted and range between -2 and $1 \%$. This could indicate that normal nitrogen fixation was the dominant nitrogen consuming process or that Mo-nitrogenase was the dominant pathway.

Research has not yet determined exactly what causes the strong $\delta^{15} \mathrm{~N}$ discrimination within the diazotrophs (Glass et al., 2010). One hypothesis is that slow growth rates and passive diffusion of nitrogen cause the fractionation of $\delta^{15} \mathrm{~N}$ isotopes, and that the depleted signal in sediment comes from the deposition of depleted biomass (Glass et al., 2010).

The negative nitrogen isotope values could also have been driven by iron abundance rather than molybdenum abundance. Studies by Zerkle et al. have found that increases in iron availability during ocean anoxia can result in the production of organic matter depleted in $\delta^{15} \mathrm{~N}$ (2008). These values are preserved in the cyanobacteria which fix $\mathrm{N}_{2}$ during periods of fluctuating nutrient input (Zerkle et al., 2008). Anoxia has been shown to increase Fe in the surface marine chemocline which makes regenerated ammonium available (Zerkle et al., 2008). When ammonium is consumed by bacteria, the $\delta^{15} \mathrm{~N}$ values fractionate up to $-6 \%$ (Zerkle et al., 2008). If this were the case, then the most anoxic periods in the Treedam core are represented by the intervals with the lowest $\delta^{15} \mathrm{~N}$ values with the highest Fe content. Extra iron could be 
provided by hydrothermal vents or terrestrial sediment influx (Zhang et al., 2013). The explanation that high Fe content causes depleted nitrogen isotope values does not align with the data from the Treedam core; therefore, this explanation is unlikely.

The diazotroph ability to fix their own nitrogen from the atmosphere gave cyanobacteria an advantage in Cretaceous marine environments, and they were undeterred by the low amounts of dissolved nitrate content in surface water (Zerkle et al., 2008; Jenkyns et al., 2007; Ohkouchi et al., 2006; Kuyper et al., 2004). Lack of dissolved nitrate in the Cretaceous Interior Seaway could have been caused by reduced sunlight or phosphorous limitation (Rau et al., 1987). Low nitrogen availability could also have been caused by denitrification in anoxic or suboxic zones with low rates of mixing (Rau et al., 1987).

The depleted nitrogen isotope signatures could also be caused by an influx of organic matter from vascular plants in mountain areas (Wada et al., 1987). Depleted signatures in this locality may be caused by terrestrial runoff. Nitrogen isotope values in chlorophylls range between -8 and $-2 \%$, so it is also possible that the $\delta^{15} \mathrm{~N}$ values in this range could reflect selective preservation of already depleted organic matter (Zerkle et al., 2008). Other possible explanations for depleted $\delta^{15} \mathrm{~N}$ values include electric discharge (Stüeken et al., 2015). The $\delta^{15} \mathrm{~N}$ range of values for electric discharge ( -15 to $-25 \%$ ) is more depleted than values for Treedam by more than $10 \%$, ruling out electricity as an explanation for this depleted excursion. (Stiueken et al., 2015). Faced with all possible explanations, diazotrophs present the closest range of $\delta^{15} \mathrm{~N}$ values to the Treedam core data (Stüeken et al., 2015).

\section{$5.4 \quad$ Trace Element Geochemistry}

Overall sedimentation rates were low as indicated by low Ti/Al values (Figure 15). Depleted carbonate isotope values (see Figure 14) are paired with low concentrations of 
carbonate trace element proxies $\mathrm{Ca} / \mathrm{Al}, \mathrm{Mg} / \mathrm{Al}$, and $\mathrm{Mn} / \mathrm{Al}$, indicating low carbonate content (see Figure 15; Rimmer et al., 2004; Murphy et al., 2000). The only depth that may have significant carbonate deposition is at 299.21 feet (91.20 meters), where there is a large spike in $\mathrm{Ca}, \mathrm{Mg}$, and $\mathrm{Mn} / \mathrm{Al}$ ratios. It is possible that this could mean a short-term drastic change in marine conditions, such as a shallowing/marine regression.

Overall redox proxies showed anoxic to suboxic environments throughout the Treedam core. The average of Treedam $\mathrm{V} /(\mathrm{V}+\mathrm{Ni})$ values is 0.76 which plots within range of anoxic marine environments (0.82 to 0.54) (Hatch and Leventhal, 1992). There are two areas in which the Treedam samples plot within the dysoxic range (0.6 to 0.46 ); these depths are around 375 feet (114.3 meters) in the DeGrey Member and from 475 to 505 feet (144.78 to 153.92 meters) in the Gregory Member (Hatch and Leventhal, 1992). V/Cr ratios show dysoxic conditions throughout the Pierre Shale, with the only major shift to anoxic environments occurring at 496.49 feet (151.33 meters) in the Gregory Member. Samples from 499 to 512 feet (152.09 to 156.05 meters) show oscillating redox conditions in the Gregory, as can be seen in the drastic shifts in $\mathrm{V} /(\mathrm{V}+\mathrm{Ni})$ and $\mathrm{V} / \mathrm{Cr}$ ratios. The Treedam $\mathrm{U} / \mathrm{Th}$ ratios fluctuate between 0.1 and 0.5 , but show values up to 0.9 at the base of the Crow Creek Member, which could indicate an anoxic shift related to the Crow Creek deposition. U/Th values above 1.25 indicate anoxic environments, while values below 0.75 indicate oxic (Jones and Manning, 1994). Uranium is concentrated in shales under anoxic conditions, so an increase in uranium usually occurs when conditions become more reducing (Algeo and Maynard, 2004; Hatch and Leventhal, 1992). $\mathrm{Mo} / \mathrm{Al}$ ratios are extremely low throughout the Treedam core, which may indicate either oxic conditions or very low Mo input from the surrounding environment (Algeo and Maynard, 2004; 
Emerson and Huested, 1991). Mo/Al ratios may not be a good proxy for redox conditions in this locality.

\subsection{Volcanic Ash Bed Geochemical Changes}

P-values in Tables 7 and 8 show that all geochemical parameters were above 0.05 , indicating that differences between the volcanic ash beds and overall Treedam core values were not statistically significant (Motulsky, 2016; Moore and McCabe, 1993). These values confirm that the deposition of volcanic ash beds does not have any significant effects on the redox conditions or paleoproductivity in the Western Interior Seaway. If there were an effect present, a higher resolution sampling interval would be needed to capture the significance of the isotopic changes. The scatter plots (Figures 17, 18, and 19) did not show any clear trends and were inconclusive.

Figure 17 showed wide scatter for all stable isotope parameters and \% TOC content. No clear trends were evident within five feet of bentonite bed deposition. Figure 18 showed that low amounts of Ti were present in the sediment, indicating a low amount of detrital sedimentary influx. The $\mathrm{Ca}, \mathrm{Mg}$, and $\mathrm{Mn}$ plots show fairly consistent values throughout the sampled interval with low scatter, indicating that ash deposition did not change clastic input or carbonate formation in the sediment. The proxies for anoxia shown in Figure 19 show that the deposition of ash beds did not change redox conditions significantly after the deposition of ash beds. Molybdenum content was negligible throughout the core. Overall the scatter plots were an insufficient method to identify consistent trends. The findings indicate that ash deposition did not significantly impact clastic influx, carbonate formation, or redox conditions in this locality. 


\subsection{Crow Creek Geochemical Changes}

Statistical analysis in Tables 6 and 7 showed that no statistically-significant divergence from overall Treedam values was observed for the Crow Creek Member. It is possible that limited sample size factored into the results of this analysis. Data was limited for the five feet (1.52 meters) below the basal Crow Creek Member contact for all scatter plots and statistical analyses, which makes interpretation of geochemical trends difficult. The scatter plot of distance from the Crow Creek Member contact vs. geochemical parameters (Figures 25 and 26) showed substantial diversion from the normal \%TOC content at the base of the Crow Creek, but there were no significant correlations in $\delta^{13} \mathrm{C}$ carb, $\delta^{13} \mathrm{C}$ org, or $\delta^{15} \mathrm{~N}$ org.

The overall Treedam $\% \mathrm{TOC}, \delta^{13} \mathrm{C}$, and $\delta^{15} \mathrm{~N}$ curves indicate that the marine setting was regressing and that the water column shallowed leading up to the Manson impact. The claim that the Crow Creek was deposited due to a marine low stand followed by a marine transgression is supported by the $\% \mathrm{TOC}$ and $\delta^{13} \mathrm{C}$ carbonate values, which both show enrichment post-Crow Creek deposition. The claim is not supported by the organic $\delta^{13} \mathrm{C}$ and $\delta^{15} \mathrm{~N}$ trends, which do not change significantly after the Crow Creek was deposited. If a marine transgression had occurred, the organic $\delta^{13} \mathrm{C}$ values would be expected to shift drastically from terrestrial to marine signatures (-27 to $-24 \%$ ) up-section from the Crow Creek Member. Since the values remain relatively constant (between -26 and $-27 \%$ ), the data indicate that a marine transgression may not have caused the deposition of the Crow Creek Member. The nitrogen isotope values would have also reflected a shift from terrestrial signatures around $0 \%$ to more enriched signatures characteristic of marine systems ( +2 to $+25 \%$ ). The nitrogen isotope values remained below $2 \%$ o throughout the core and the majority of the isotope data ranged from 0 to $-3 \%$. This indicates that there was very little nitrogen consumption by primary producers other than cyanobacteria 
using nitrogenase enzymes, and a shift from terrestrial to marine nitrogen consumption is not evident.

The scatter plots for clastic influx proxies before and after Crow Creek Member deposition showed conflicting interpretations of the origin of the Crow Creek Member. A decrease in $\mathrm{Ti} / \mathrm{Al}$ and $\mathrm{Mg} / \mathrm{Al}$ ratios and an increase in $\mathrm{Ca} / \mathrm{Al}$ and $\mathrm{Mn} / \mathrm{Al}$ ratios are shown within four feet (1.21 meters) of Crow Creek deposition. These findings may indicate that sedimentary influx decreased while carbonate formation increased at the time the depositional event occurred, before reverting to background levels. There may have also been an increase in productivity that resulted in increased $\mathrm{Ca}$ and $\mathrm{Mn}$ content. Redox proxies for before and after the Crow Creek Member deposition show an increase in U/Th and Mo/Al at the base of the Crow Creek Member, $\mathrm{V} / \mathrm{Cr}$ is depleted at the base of the Crow Creek and no significant change is seen in $\mathrm{V} /(\mathrm{V}+\mathrm{Ni})$.

There were not enough $\delta^{13} \mathrm{C}$ carbonate isotope values or \% TOC values to accurately tell if the deposition of the Crow Creek Member was correlated with changes in $\%$ TOC or $\delta^{13} \mathrm{C}$ carb. A larger sample size was not available due to the unconsolidated nature of the Crow Creek Member in the Treedam core. The carbonate data also show depleted values (as low as -15\%o) throughout the Gregory Member and shift to between 0 and $-5 \%$ above the Crow Creek Member. This could indicate that the Gregory was deposited in a much shallower marine environment and therefore had a greater input of terrestrial light carbon.

\section{CHAPTER 6: CONCLUSIONS}

Overall trends of $\delta^{13}$ Corg in the Treedam core indicate a brackish shallow marine environment, which is similar to the paleoenvironmental interpretations of Patrick et al. (2007) for this research area. The limited range of $\delta^{13}$ Corg values ( -27 to $-26 \%$ ) indicates that there were likely no drastic changes in sea level. Rare earth element signatures of fossil mosasaurs 
collected near the Treedam locality in a separate study suggests that the water was seasonally stratified, possibly due to salinity or temperature differences, which may have reduced oxygen circulation (Patrick et al., 2004).

The Treedam $\delta^{15} \mathrm{~N}$ values range from -6 to $+1 \%$, which differ from more typical nitrogen marine isotope ranges $(-1 \%$ to $8 \%$ ). The wide scatter of nitrogen isotope data is likely caused by varying nitrogen sources and redox conditions in a shallow marine system. The nitrogen isotope and weight percent ranges indicate that the Treedam marine paleoenvironment was limited in both molybdenum and fixed nitrogen content. These limitations likely caused diazotrophs to switch to nitrogen fixation via $\mathrm{V}$ or Fe-nitrogenase pathways. Low $\mathrm{N}$ and Mo concentrations support the idea that that the major nitrogen sources for the Pierre Shale were cyanobacteria. The lowest part of this nitrogen stable isotope range matches similar ranges for atmospheric nitrogen fixing cyanobacteria when using Fe or V-nitrogenase enzyme mechanisms. Similar $\delta^{15} \mathrm{~N}$ trends have been found in Cretaceous oceanic anoxic events; therefore, it is possible that these cyanobacteria continued to thrive in anoxic conditions (Zhang et al., 2014).

In the Treedam core, low productivity combined with low fixed nitrogen content in the Gregory, Crow Creek, and DeGrey were most likely caused by anoxic bottom water conditions. $\mathrm{N}_{2}$ fixation during the Cretaceous OAE II occurred in environments depleted in oxygen, depleted in nitrogen content and rich in organic carbon accumulation, and a study buy Kuypers et al. yielded similar $\delta^{15} \mathrm{~N}$ values to those of the Treedam core (2004). Atmospheric $\mathrm{N}_{2}$ fixation is energy-intensive; therefore, diazotrophs would have only outcompeted non-fixing algae when nitrogen concentrations were low relative to phosphorous content (Kuypers et al., 2004). During the Late Campanian, low nitrogen and carbon content in the surface water of the Western Interior 
Seaway resulted in a competitive advantage for cyanobacteria which fix atmospheric nitrogen rather than consume previously fixed nitrogen.

No statistically-significant correlations were found between any geochemical proxies and distance above volcanic ash beds. Statistical analysis using $\mathrm{T}$ and $\mathrm{Z}$ statistics yielded no statistically significant differences between geochemical proxies of the Crow Creek Member or volcanic ash beds and the overall averages present in the Treedam core. No conclusions can be drawn from statistical analysis of the volcanic ash beds. Higher resolution data is needed in order to verify the trends beyond a doubt.

There were no observed changes in $\% \mathrm{TOC}, \delta^{13} \mathrm{Corg}, \delta^{15} \mathrm{~N}$, or $\mathrm{C} / \mathrm{N}$ weight percent ratios above the volcanic ash beds. There were slight decreases in $\delta^{13} \mathrm{C}$ carb after deposition of volcanic ash beds; however, it is difficult to assess these in a shallow brackish system which has many varying inputs and signals. While it is evident that volcanic ash can cause increases in marine productivity, the $\mathrm{pH}$ buffering effects described by Kockum et al. (2005) likely reduced the changes in redox conditions and paleoproductivity. The volcanic ash carbon and nitrogen isotope comparison revealed a wide scatter in isotope values, which may have been caused by the variation in marine geochemical conditions found in brackish marine depositional environments. It is difficult to tell if the changes in geochemical parameters were caused by ash deposition, or by higher-resolution short-term variation in the shallow marine system. The preexisting variation in background geochemical records makes it difficult to isolate the changes caused by ash deposition. Further research should be done on geochemical signatures of ash beds in a less variable marine system so that the changes can be more easily identified from the overall changes in marine geochemistry. 
The Crow Creek Member spans approximately 263,000 years according to a sedimentation rate of $1.16 \mathrm{~cm} / 1000$ years established by Hanczaryk and Gallagher (2007). The overall isotope and TOC records show that \% TOC increases and $\delta^{15} \mathrm{~N}$ values shift from +1 to 2\%o within five feet $(1.5 \mathrm{~m} / 131,500$ years $)$ of the Crow Creek Member contact. The high-energy deposition of the unconsolidated sand by an impact-induced tsunami may have leached trace elements out of the newly-deposited terrestrial sediment into the benthic substrate and provided nutrients for blooms of algae, resulting in an increase in organic carbon deposition immediately above the Crow Creek Member; however, this does not explain the depletion in nitrogen isotopes. Depleted nitrogen signatures combined with increased \%TOC suggest that the Manson impact may have induced a short period of anoxia and lower productivity, and an increase in organic carbon burial via increased turbidity in the water column resulting in the death and burial of photosynthetic organisms.

Concerning the origin of the Crow Creek Member, trace element data are inconclusive. There were no statistically-significant correlations found between the Crow Creek Member depositional event and increased trace element ratios. A sharp basal contact, rip-up clasts, impact ejecta and shocked mineral grains provide evidence for a high-energy depositional environment caused by an impact (Hanczaryk and Gallagher, 2007; Izett et al., 1997). The Crow Creek sand is limited to five feet $(1.52 \mathrm{~m})$ out of 500 feet $(152.4 \mathrm{~m})$ of massive black shale, indicating that the depositional event was isolated throughout the depositional history of the Pierre Shale. Given consistent organic carbon isotope data throughout fve hundred feet of core, it seems unlikely that there was a drastic change in sea level. Therefore, the Crow Creek Member was most likely deposited by an impact tsunami. 


\section{REFERENCES CITED}

Algeo, T., and Maynard, J. (2004). Trace-element behavior and redox facies in core shales of Upper Pennsylvanian Kansas-type cyclothems. Chemical Geology, 289-318.

Altabet, M., and Francois, R. (1994). Sedimentary nitrogen isotopic ratio as a recorder for surface ocean nitrate utilization. Global Biogeochemical Cycles, 8(1), 103-116.

Aller, R. (1994). Bioturbation and remineralization of sedimentary organic matter: Effects of redox oscillation. Chemical Geology, 114, 331-345.

Arbor, A. (1994). Preservation of elemental and isotopic source identification of sedimentary organic matter. Chemical Geology, 114, 289-302.

Arthur, M. A., Dean, W. E., and Claypool, G. E. (1985). Anomalous 13C enrichment in modern marine organic carbon. Nature, 315, 216-218.

Bernoulli, D., Schaltegger, U., Stern, W., Frey†, M., Caron, M., and Monechi, S. (2004). Volcanic ash layers in the Upper Cretaceous of the Central Apennines and a numerical age for the early Campanian. International Journal of Earth Sciences, 93(3), 384-399.

Bertog, J. L. (2013). Timing of Onset of Volcanic Centers in the Campanian of Western North America as Determined by Distal Ashfalls. Open Journal of Geology, 03(02), 121-133. doi:10.4236/ojg.2013.32016

Bertog, J., Huff, W., and Martin, J.E. (2007). Geochemical and mineralogical recognition of the bentonites in the lower Pierre Shale Group and their use in regional stratigraphic correlation, in Martin, J.E., and Parris, D.C., eds., Geology and Paleontology of the Late Cretaceous Marine Deposits of the Dakotas: Geological Society of America Special Paper 427. 
Blakey, R. (2014). Western Interior Seaway -- Jurassic and Cretaceous Epicontinental Seas of North America. Retrieved May 05, 2016, from http://cpgeosystems.com/wispaleogeography.html

Brady, A. L., Druschel, G., Leoni, L., Lim, D. S. S., and Slater, G. F. (2013). Isotopic biosignatures in carbonate-rich, cyanobacteria-dominated microbial mats of the Cariboo Plateau, B.C. Geobiology, 11(5), 437-456. http://doi.org/10.1111/gbi.12050

Brathwaite, L. D. (2009). Shale-Deposited Natural Gas: A Review of Potential. California Energy Commission.1-30. Retrieved from http://www.energy.ca.gov/2009publications/CEC-200-2009-005/CEC-200-2009-005SD.PDF

Cadrin, A., Kyser, T., Caldwell, W., and Longstaffe, F. (1995). Isotopic and chemical compositions of bentonites as paleoenvironmental indicators of the Cretaceous Western Interior Seaway. Palaeogeography, Palaeoclimatology, Palaeoecology, 119, 301-320.

Calvert, S. E., Bustin, R. M., and Ingall, E. D. (1996). Influence of water column anoxia and sediment supply on the burial and preservation of organic carbon in marine shales. Geochimica et Cosmochimica Acta, 60(9), 1577-1593. http://doi.org/10.1016/0016$\underline{7037(96) 00041-5}$

Chen, R., Sharma, S., Bank, T., Soeder, D., and Eastman, H. (2015). Comparison of isotopic and geochemical characteristics of sediments from a gas- and liquids-prone wells in Marcellus Shale from Appalachian Basin, West Virginia. Applied Geochemistry, 60, 5971. http://doi.org/10.1016/j.apgeochem.2015.01.001

Chen, R., and Sharma, S. (2016). Role of alternating redox conditions in the formation of organic-rich interval in the Middle Devonian Marcellus Shale, Appalachian Basin, USA. 
Palaeogeography, Palaeoclimatology, Palaeoecology, 446, 85-97. http://doi.org/10.1016/j.palaeo.2016.01.016

Christidis, G. (2008). Do bentonites have contradictory characteristics? An attempt to answer unanswered questions. Clay Minerals, 43, 515-529.

Cline, J., and Kaplan, I. (1975). Isotopic fractionation of dissolved nitrate during denitrification in the eastern tropical north pacific ocean. Marine Chemistry, 3, 271-299.

Corbett, M., and Watkins, D. (2013). Calcareous nannofossil paleoecology of the midCretaceous Western Interior Seaway and evidence of oligotrophic surface waters during OAE2. Palaeogeography, Palaeoclimatology, Palaeoecology, 392, 510-523.

Crandell, D. (1958). Geology of the Pierre Area, South Dakota. U.S. Geological Survey Professional Paper 307, 1-88.

Dean, W. E., Arthur, M. A., and Claypool, G. E. (1986). Depletion of 13C in Cretaceous marine organic matter: Source, diagenetic, or environmental signal? Marine Geology, 70(1-2), 119-157. doi:10.1016/0025-3227(86)90092-7

Dean, W., Arthur, M., and Stow, D. (1984). Origin and geochemistry of Cretaceous deep-sea black shales and multicolored claystones with emphasis on Deep Sea Drilling Project Site 530, southern Angola basin. U.S. Geological Survey Initial Reports of the Deep Sea Drilling Project, 75(2), 819-844.

Demaison, G., and Moore, G. (1980). Anoxic environments and oil source bed genesis. AAPG Bulletin, 64, 1179-1209.

Emerson, S. R., and Huested, S. S. (1991). Ocean anoxia and the concentrations of molybdenum and vanadium in seawater. Marine Chemistry, 34(3-4), 177-196. http://doi.org/10.1016/0304-4203(91)90002-E 
Farquhar, G., Ehleringer, J., and Hubick, K. (1989). Carbon Isotope Discrimination and Photosynthesis. Annual Review of Plant Physiology and Plant Molecular Biology, 40, $503-537$.

Felitsyn, S., and Kirianov, V. (2001). Mobility of phosphorous during the weathering of volcanic ashes. Lithology and Mineral Resources, 37(3), 275-278.

Flaathen, T., and Gislason, S. (2007). The effect of volcanic eruptions on the chemistry of surface waters: The 1991 and 2000 eruptions of Mt. Hekla, Iceland. Journal of Volcanology and Geothermal Research, 164, 293-316.

Fox, J. E. (2007). Mollusks from the late Campanian upper DeGrey Formation of the Pierre Shale Group, Missouri River Valley, central South Dakota. Special Paper 427: The Geology and Paleontology of the Late Cretaceous Marine Deposits of the Dakotas, 427, 8598.

Freeman, K. H. (2001). Isotopic Biogeochemistry of Marine Organic Carbon. Reviews in Mineralogy and Geochemistry, 43(1), 579-605.

Freudenthal, T., Wagner, T., Wenzhofer, F., Zabel, M., Wefer, G. (2001). Early diagenesis of organic matter from sediments of the eastern subtropical Atlantic: evidence from stable nitrogen and carbon isotopes. Geochimica et Cosmochimica Acta , 65, 1795-1808.

Galy, V., France-Lanord, C., Beyssac, O., Faure, P., Kudrass, H., and Palhol, F. (2007). Efficient organic carbon burial in the Bengal fan sustained by the Himalayan erosional system. Nature, 450(November), 407-410. http://doi.org/10.1038/nature06273

Garavito, A., Kooi, H., and Neuzil, C. (2006). Numerical Modeling of A Long-term In Situ Chemical Osmosis Experiment In The Pierre Shale, South Dakota. Advances in Water Resources, (29), 481-492. 
Geotek Ltd., Geotek Multi-Sensor Core Logger Flyer. Daventry, UK 2009.

Glass, J. B., Wolfe-Simon, F., Elser, J. J., and Anbar, A. D. (2010). Molybdenum-nitrogen colimitation in freshwater and coastal heterocystous cyanobacteria. Limnology and Oceanography, 55(2), 667-676. http://doi.org/10.4319/lo.2009.55.2.0667

Hanczaryk, P., and Gallagher, W. (2007). Stratigraphy and paleoecology of the middle Pierre Shale along the Missouri River, central South Dakota. Special Paper 427: The Geology and Paleontology of the Late Cretaceous Marine Deposits of the Dakotas, 51-69.

Hatch, J., and Leventhal, J. (1992). Relationship between inferred redox potential of the depositional environment and geochemistry of the Upper Pennsylvanian (Missourian) Stark Shale Member of the Dennis Limestone, Wabaunsee County, Kansas, U.S.A. Chemical Geology, 99(1-3), 65-82.

Hayes, J. (1993). Factors controlling 13C contents of sedimentary organic compounds: Principles and evidence. Marine Geology, 113, 111-125.

Hinga, K., Arthur, M., Pilson, M., and Whitaker, D. (1994). Carbon isotope fractionation by marine phytoplankton in culture: The effects of $\mathrm{CO} 2$ concentration, $\mathrm{p} \mathrm{H}$, temperature, and species. Global Biogeochem. Cycles Global Biogeochemical Cycles, 8(1), 91-102.

Ibach, L. E. (1982). Relationship Between Sedimentation Rate and Total Organic Carbon Content in Ancient Marine Sediments. Bulletin AAPG Bulletin, 66(2), 170-188.

Izett, G., Cobban, W., Obradovich, J., and Dalrymple, G. (1998). 40Ar/39Ar age of the Manson impact structure, Iowa, and correlative impact ejecta in the Crow Creek Member of the Pierre Shale (Upper Cretaceous), South Dakota and Nebraska. Geological Society of America Bulletin, 110(3), 361-376. 
Jarvis, I., Gale, A., Jenkyns, H., and Pearce, M. (2006). Secular variation in Late Cretaceous carbon isotopes: A new $\delta 13 \mathrm{C}$ carbonate reference curve for the Cenomanian-Campanian (99.6-70.6 Ma). Geological Magazine, 143, 561-608.

Jarvis, I., Lignum, J., Gröcke, D., Jenkyns, H., and Pearce, M. (2011). Black shale deposition, atmospheric $\mathrm{CO}_{2}$ drawdown, and cooling during the Cenomanian-Turonian Oceanic Anoxic Event. Paleoceanography, 26(3), 1-17.

Jenkyns, H., Gröcke, D., and Hesselbo, S. (2001). Nitrogen isotope evidence for water mass denitrification during the Early Toarcian (Jurassic) oceanic anoxic event. Paleoceanography, 60(6), 593-603.

Jenkyns, H. C., Matthews, A., Tsikos, H., and Erel, Y. (2007). Nitrate reduction, sulfate reduction, and sedimentary iron isotope evolution during the Cenomanian-Turonian oceanic anoxic event. Paleoceanography, 22(3), 1-17.

Jones, M., and Gislason, S. (2008). Rapid releases of metal salts and nutrients following the deposition of volcanic ash into aqueous environments. Geochimica Et Cosmochimica Acta, 72, 3661-3680.

Jones, B., and Manning, D. A. (1994). Comparison of geochemical indices used for the interpretation of palaeoredox conditions in ancient mudstones. Chemical Geology, 111(14), 111-129. doi:10.1016/0009-2541(94)90085-x

Kashiyama, Y., Ogawa, N. O., Kuroda, J., Shiro, M., Nomoto, S., Tada, R., . . Ohkouchi, N. (2008). Diazotrophic cyanobacteria as the major photoautotrophs during mid-Cretaceous oceanic anoxic events: Nitrogen and carbon isotopic evidence from sedimentary porphyrin. Organic Geochemistry, 39(5), 532-549.

doi:10.1016/j.orggeochem.2007.11.010 
Katongo, C., Koeberl, C., Witzke, B., Hammond, R., and Anderson, R. (2004). Geochemistry and shock petrography of the Crow Creek Member, South Dakota, USA: Ejecta from the 74-Ma Manson impact structure. Meteoritics and Planetary Science, 39(1), 31-51.

Khim, B., Bahk, J., Hyun, S., and Lee, G. (2007). Late Pleistocene dark laminated mud layers from the Korea Plateau, western East Sea/Japan Sea, and their paleoceanographic implications. Palaeogeography, Palaeoclimatology, Palaeoecology, 247, 74-87.

Khim, B., Ikehara, K., Bahk, J., and Irino, T. (2008). Increased negative anomalies of sedimentary organic matter $\delta 13 \mathrm{C}$ and $\delta 15 \mathrm{~N}$ values in the East Sea (Sea of Japan) during the full glaciation of the late Quaternary. Quaternary International, 176-177, 25-35.

Kockum, P., Herbert, R., and Gislason, S. (2006). A diverse ecosystem response to volcanic aerosols. Chemical Geology, 231, 57-66.

Kooli, F. (2013). Effect of C16TMA contents on the thermal stability of organo-bentonites: In situ X-ray diffraction analysis. Thermochimica Acta, 551, 7-13. http://doi.org/10.1016/j.tca.2012.09.038

Kuypers, M. M. M., van Breugel, Y., Schouten, S., Erba, E., and Damsté, J. S. S. (2004). N2fixing cyanobacteria supplied nutrient $\mathrm{N}$ for Cretaceous oceanic anoxic events. Geology, 32(10), 853-856. http://doi.org/10.1130/G20458.1

Langmann, B., Zakšek, K., Hort, M., and Duggen, S. (2010). Volcanic ash as fertiliser for the surface ocean. Atmos. Chem. Phys. Atmospheric Chemistry and Physics, 10, 3891-3899.

Leckie, R., Bralower, T., and Cashman, R. (2002). Oceanic anoxic events and plankton evolution: Biotic response to tectonic forcing during the mid-Cretaceous. Paleoceanography, 17(3), 1-29. 
Lehmann, M.F., Bernasconi, S.M., Barbieri, A., McKenzie, J.A. (2002). Preservation of organic matter and alteration of its carbon and nitrogen isotope composition during simulated and in situ early sedimentary diagenesis. Geochimica et Cosmochimica Acta, 66, 3573-3584.

Li, L., and Bebout, G. (2005). Carbon and nitrogen geochemistry of sediments in the Central American convergent margin: Insights regarding subduction input fluxes, diagenesis, and paleoproductivity. Journal of Geophysical Research, 110.

Locklair, R., Sageman, B., and Lerman, A. (2011). Marine carbon burial flux and the carbon isotope record of Late Cretaceous (Coniacian-Santonian) Oceanic Anoxic Event III. Sedimentary Geology, 235(1), 38-49.

Louis-Schmid, B., Rais, P., Schaeffer, P., Bernasconi, S. M., and Weissert, H. (2007). Plate tectonic trigger of changes in $\mathrm{p} \mathrm{CO}_{2}$ and climate in the Oxfordian (Late Jurassic): Carbon isotope and modeling evidence. Earth and Planetary Science Letters, 258(1-2), 44-60. http://doi.org/10.1016/j.eps1.2007.03.014

Lyons, T., Anbar, A., Severmann, S., Scott, C., and Gill, B. (2009). Tracking Euxinia in the Ancient Ocean: A Multiproxy Perspective and Proterozoic Case Study. Annual Review of Earth and Planetary Sciences, 37, 507-534.

Mangini, A., Jung, M., and Laukenmann, S. (2001). What do we learn from peaks of uranium and of manganese in deep sea sediments? Marine Geology, 117, 63-78.

Martin, J., Bertog, J., and Parris, D. (2007). Revised lithostratigraphy of the lower Pierre Shale Group (Campanian) of central South Dakota, including newly designated Members. The Geology and Paleontology of the Late Cretaceous Marine Deposits of the Dakotas: Geological Society of America Special Paper, 427, 9-21. 
Maynard, J. B. (1981). Carbon isotopes as indicators of dispersal patterns in DevonianMississippian shales of the Appalachian Basin. Geology, 9(6), 262-265.

Meyer, K., and Kump, L. (2008). Oceanic Euxinia in Earth History: Causes and Consequences. Annual Review of Earth and Planetary Sciences Annu. Rev. Earth Planet. Sci., 36, 251288.

Meyers, P. (1992). Changes in organic carbon stable isotope ratios across the K/T boundary: Global or local control? Chemical Geology: Isotope Geoscience Section, 101, 283-291.

Meyers, P. (1994). Preservation of Elemental and Isotopic Source Identification of Sedimentary Organic Matter. Chemical Geology, 114(3-4), 289-302.

Meyers, P., and Ishiwatari, R. (1993). Lacustrine Organic Geochemistry — an Overview of Indicators of Organic Matter Sources and Diagenesis in Lake Sediments. Organic Geochemistry, 20(7), 867-900.

Minoura, K., Hoshino, K., Nakamura, T., and Wada, E. (1997). Late Pleistocene-Holocene paleoproductivity circulation in the Japan Sea: Sea-level control on $\delta 13 \mathrm{C}$ and $\delta 15 \mathrm{~N}$ records of sediment organic material. Palaeogeography, Palaeoclimatology, Palaeoecology, 135, 41-50.

Moore, D. S., and McCabe, G. P. (2002). Introduction to the practice of statistics (4th ed.). New York: Freeman.

Moore, D. M., and Reynolds, R. C. (1989). X-ray diffraction and the identification and analysis of clay minerals. Oxford: Oxford University Press.

Motulsky, H. (2016). P-Value Calculator [Computer software]. Retrieved September 5, 2016, from https://graphpad.com/quickcalcs/PValue1.cfm 
Murphy, A., Sageman, B., Hollander, D., Lyons, T., and Brett, C. (2000). Black shale deposition and faunal overturn in the Devonian Appalachian Basin: Clastic starvation, seasonal water-column mixing, and efficient biolimiting nutrient recycling. Paleoceanography, 15(3), 280-291.

Nicholls, E. (1989). Marine vertebrates of the Pembina Member of the Pierre Shale (Campanian, Upper Cretaceous) of Manitoba and their significance to the biogeography of the Western Interior Seaway. Ph.D. Thesis Univ. Calgary (1989)

Ohkouchi, N., Kashiyama, Y., Kuroda, J., Ogawa, N. O., and Kitazato, H. (2006). The importance of diazotrophic cyanobacteria as primary producers during Cretaceous Oceanic Anoxic Event 2. Biogeosciences, 3(4), 467-478. http://doi.org/10.5194/bgd-3$\underline{575-2006}$

Oueslati, W., Rhaiem, H. B., and Amara, A. B. H. (2011). XRD investigations of hydrated homoionic montmorillonite saturated by several heavy metal cations. Desalination, 271(1-3), 139-149. http://doi.org/10.1016/j.desal.2010.12.018

Patrick, D., Martin, J., Parris, D., and Grandstaff, D. (2004). Paleoenvironmental interpretations of rare earth element signatures in mosasaurs (reptilia) from the upper Cretaceous Pierre Shale, central South Dakota, USA. Palaeogeography, Palaeoclimatology, Palaeoecology, 212(3), 277-294.

Peterson, B., Howarth, R., and Garritt, R. (1985). Multiple Stable Isotopes Used to Trace the Flow of Organic Matter in Estuarine Food Webs. Science, 227, 1361-1363.

Quan, T. M., Wright, J. D., \& Falkowski, P. G. (2013). Co-variation of nitrogen isotopes and redox states through glacial-interglacial cycles in the Black Sea. Geochimica et Cosmochimica Acta,112, 305-320. doi:10.1016/j.gca.2013.02.029 
Quan, T. M., van de Schootbrugge, B., Field, M. P., Rosenthal, Y., and Falkowski, P. G. (2008). Nitrogen isotope and trace metal analyses from the Mingolsheim core (Germany): Evidence for redox variations across the Triassic-Jurassic boundary. Global Biogeochemical Cycles, 22(2), 1-14. http://doi.org/10.1029/2007GB002981

Ramkumar, M. (2015). Chemostratigraphy: Concepts, techniques, and applications. Elsevier.

Rau, G. H., Arthur, M. A., and Dean, W. E. (1987). 15N/14N variations in Cretaceous Atlantic sedimentary sequences: implication for past changes in marine nitrogen biogeochemistry. Earth and Planetary Science Letters, 82(3-4), 269-279. http://doi.org/10.1016/0012-

\section{$\underline{821 X(87) 90201-9}$}

Rau, G., Takahashi, T., and Marais, D. (1989). Latitudinal variations in plankton $\delta 13 C$ : Implications for $\mathrm{CO}_{2}$ and productivity in past oceans. Nature, 341, 516-518.

Rimmer, S., Thompson, J., Goodnight, S., and Robl, T. (2004). Multiple controls on the preservation of organic matter in Devonian-Mississippian marine black shales: geochemical and petrographic evidence. Palaeogeography, Palaeoclimatology, Palaeoecology, 215(1-2), 125-154.

Sackett, W., Eckelmann, W., Bender, M., and Be, A. (1965). Temperature Dependence of Carbon Isotope Composition in Marine Plankton and Sediments. Science, 148, 235-237.

Schacht, U., Wallmann, K., and Kutterolf, S. (2010). The influence of volcanic ash alteration on the REE composition of marine pore waters. Journal of Geochemical Exploration, 106, $176-187$.

Schmitz, B. (1987). The ratio in the Cenozoic Bengal Abyssal Fan sediments and its use as a paleostream energy indicator. Marine Geology, 76, 195-206. 
Sharp, Z. (2007). Nitrogen. In Principles of stable isotope geochemistry (1st ed., pp. 206-215). Upper Saddle River, New Jersey: Pearson/Prentice Hall.

Sharp, Z. (2007). Carbon in the low temperature environment. In Principles of stable isotope geochemistry (1st ed., pp. 149-178). Upper Saddle River, New Jersey: Pearson/Prentice Hall.

Shen, J., Lei, Y., Algeo, T., Feng, Q., Servais, T., Yu, J., and Zhou, L. (2013). Volcanic Effects On Microplankton During The Permian-Triassic Transition (Shangsi And Xinmin, South China). PALAIOS, 28, 552-567.

Shen, J., Algeo, T., Zhou, L., Feng, Q., Yu, J., and Ellwood, B. (2012). Volcanic perturbations of the marine environment in South China preceding the latest Permian mass extinction and their biotic effects. Geobiology, (10), 82-103.

Shimmield, G. (1992). Can sediment geochemistry record changes in coastal upwelling palaeoproductivity? Evidence from northwest Africa and the Arabian Sea. Geological Society, London, Special Publications, 64, 29-46.

Spofforth, D. J. A., Agnini, C., Pälike, H., Rio, D., Fornaciari, E., Giusberti, L., Luciani, V., Lanci, L., and Muttoni, G. (2010). Organic carbon burial following the middle Eocene climatic optimum in the central western Tethys. Paleoceanography, 25(3), 1-11. http://doi.org/10.1029/2009PA001738mot

Sigman, D., Karsh, K., and Casciotti, K. (2009). Ocean Process Tracers: Nitrogen Isotopes in the Ocean. Encyclopedia of Ocean Sciences, 4138-4153. http://doi.org/10.1006/rwos.2001.0172

Smith, L and Leone, J. (2010, April). Integrated characterization of Utica and Marcellus black shale gas plays, New York State Presentation at American Association of Petroleum 
Geologists Annual Convention and Exhibition, New Orleans, Louisiana. Abstract retrieved from http://www.searchanddiscovery.com/documents/2010/50289smith/ndx_smith.pdf

Stein, R. (1991). Accumulation of organic carbon in marine sediments: Results from the Deep Sea Drilling Project/Ocean Drilling Program (DSDP/ODP) (pp. 1-39). Berlin: SpringerVerlag.

Stoffer, P. W. (1998). Stratigraphy of the upper Pierre Shale and Fox Hills Formation (Campanian and Maastrichtian; Late Cretaceous) in the Badlands National park region, South Dakota: Implications for eustatic changes in sea level, tectonism, and marine paleoecology of the western interior seaway (Doctoral dissertation). Retrieved from UMI City University, New York. (UMI number: 9830765)

Stiueken, E. E., Buick, R., Guy, B. M., and Koehler, M. C. (2015). Isotopic evidence for biological nitrogen fixation by molybdenum-nitrogenase from 3.2 Gyr. Nature, 105, 1302-1312. http://doi.org/10.1038/nature14180

Thompson, C., Kah, L., Astini, R., Bowring, S., and Buchwaldt, R. (2012). Bentonite geochronology, marine geochemistry, and the Great Ordovician Biodiversification Event (GOBE). Palaeogeography, Palaeoclimatology, Palaeoecology, 321-322, 88-101.

Totten, M., Jurik, M., and Hanan, M. (2005). The occurrence and seismic expression of volcanic ash beds in the Gulf of Mexico. Gulf Coast Association of Geological Societies Transactions, 55, 810-820.

Tribovillard, N., Algeo, T., Lyons, T., and Riboulleau, A. (2006). Trace metals as paleoredox and paleoproductivity proxies: An update. Chemical Geology, 232(1-2), 12-32. 
Varricchio, D. J., Raven, R. F., Wolbach, W. S., Elsik, W. C., and Witzke, B. J. (2009). Soot and palynologic analysis of Manson impact-related strata (Upper Cretaceous) of Iowa and South Dakota, USA. Cretaceous Research, 30(1), 127-134.

\section{http://doi.org/10.1016/j.cretres.2008.06.005}

Velinsky, D., Fogel, M., Todd, J., and Tebo, B. (1991). Isotopic fractionation of dissolved ammonium at the oxygen-hydrogen sulfide interface in anoxic waters. Geophysical Research Letters, 18, 649-652.

Wada, E., Minagawa, M., Mizutani, H., Tsuji, T., Imaizumi, R., and Karasawa, K. (1987). Biogeochemical studies on the transport of organic matter along the Otsuchi River watershed, Japan. Estuarine, Coastal and Shelf Science, 25(3), 321-336.

\section{http://doi.org/10.1016/0272-7714(87)90075-8}

Wang, X., Cui, L., Xiao, J., and Ding, Z. (2013). Stable carbon isotope of black carbon in lake sediments as an indicator of terrestrial environmental changes: An evaluation on paleorecord from Daihai Lake, Inner Mongolia, China. Chemical Geology, 347, 123-134.

Waseda, A., Didyk, B., and Kajiwara, Y. (1995). Carbon Isotope Compositions of Organic Matter from the Chile Continental Margin. Proceedings of the Ocean Drilling Program, Scientific Results, 141, 299-305.

Werne, J. P., Sageman, B. P., Lyons, T. W., and Hollander, D. J. (2002). An integrated assessment of a "type euxinic" deposit: evidence for multiple controls on black shale deposition in the Middle Devonian Oatka Creek Formation. American Journal of Science, 302, 110 -143. http://doi.org/10.2475/ajs.302.2.110 
Weber, R. D., and Watkins, D. K. (2007). Evidence from the Crow Creek Member (Pierre Shale) for an impact-induced resuspension event in the late Cretaceous Western Interior Seaway. Geology, 35(12), 1119-1119.

White, W. (2015). Isotope geochemistry (pp. 264-275). Ithica, New York: John Wiley and Sons. Wignall, P., and Twitchett, R. (1996). Oceanic Anoxia and the End Permian Mass Extinction. Science, 272(5265), 1155-1158.

Zagorski, W. A., Wrightstone, G. R., and Bowman, D. C. (2012). The Appalachian Basin Marcellus Gas Play: Its History of Development, Geologic Controls on Production, and Future Potential as a World-class Reservoir. AAPG Memoir, 97, 172. doi:10.1306/13321465M973491

Zakharov, Y., Haggart, J., Beard, G., and Safronov, P. (2013). Late Cretaceous climatic trends and a positive carbon isotope excursion at the Santonian-Campanian boundary in British Columbia, northeastern Pacific. Sedimentary Geology, 295, 77-92.

Zerkle, A. L., Junium, C. K., Canfield, D. E., and House, C. H. (2008). Production of 15Ndepleted biomass during cyanobacterial N 2-fixation at high Fe concentrations. Journal of Geophysical Research: Biogeosciences, 113(3), 1-9. http://doi.org/10.1029/2007JG000651

Zhang, X., Sigman, D. M., Morel, F. M. M., and Kraepiel, A. M. L. (2014). Nitrogen isotope fractionation by alternative nitrogenases and past ocean anoxia. PNAS, 111(13), 47824787. http://doi.org/10.1073/pnas.1402976111 